\title{
The hyperpycnite problem
}

\author{
G. Shanmugam
}

\begin{abstract}
Sedimentologic, oceanographic, and hydraulic engineering publications on hyperpycnal flows claim that (1) river flows transform into turbidity currents at plunge points near the shoreline, (2) hyperpycnal flows have the power to erode the seafloor and cause submarine canyons, and, (3) hyperpycnal flows are efficient in transporting sand across the shelf and can deliver sediments into the deep sea for developing submarine fans. Importantly, these claims do have economic implications for the petroleum industry for predicting sandy reservoirs in deep-water petroleum exploration. However, these claims are based strictly on experimental or theoretical basis, without the supporting empirical data from modern depositional systems. Therefore, the primary purpose of this article is to rigorously evaluate the merits of these claims.

A global evaluation of density plumes, based on 26 case studies (e.g., Yellow River, Yangtze River, Copper River, Hugli River (Ganges), Guadalquivir River, Río de la Plata Estuary, Zambezi River, among others), suggests a complex variability in nature. Real-world examples show that density plumes (1) occur in six different environments (i.e., marine, lacustrine, estuarine, lagoon, bay, and reef); (2) are composed of six different compositional materials (e.g., siliciclastic, calciclastic, planktonic, etc.); (3) derive material from 11 different sources (e.g., river flood, tidal estuary, subglacial, etc.); (4) are subjected to 15 different external controls (e.g., tidal shear fronts, ocean currents, cyclones, tsunamis, etc.); and, (5) exhibit 24 configurations (e.g., lobate, coalescing, linear, swirly, U-Turn, anastomosing, etc.).

Major problem areas are: (1) There are at least 16 types of hyperpycnal flows (e.g., density flow, underflow, high-density hyperpycnal plume, high-turbid mass flow, tide-modulated hyperpycnal flow, cyclone-induced hyperpycnal turbidity current, multi-layer hyperpycnal flows, etc.), without an underpinning principle of fluid dynamics. (2) The basic tenet that river currents transform into turbidity currents at plunge points near the shoreline is based on an experiment that used fresh tap water as a standing body. In attempting to understand all density plumes, such an experimental result is inapplicable to marine waters (sea or ocean) with a higher density due to salt content. (3) Published velocity measurements from the Yellow River mouth, a classic area, are of tidal currents, not of hyperpycnal flows. Importantly, the presence of tidal shear front at the Yellow River mouth limits seaward transport of sediments. (4) Despite its popularity, the hyperpycnite facies model has not been validated by laboratory experiments or by real-world empirical field data from modern settings.

(5) The presence of an erosional surface within a single hyperpycnite depositional unit is antithetical to the basic principles of stratigraphy. (6) The hypothetical model of "extrabasinal turbidites", deposited by river-flood triggered hyperpycnal flows, is untenable. This is because high-density turbidity currents, which serve as the conceptual basis for the model, have never been documented in the world's oceans. (7) Although plant remains are considered a criterion for recognizing hyperpycnites, the "Type 1" shelf-incising canyons having heads with connection to a major river or estuarine system could serve as a conduit for transporting plant remains by other processes, such as tidal currents. (8) Genuine hyperpycnal flows are feeble and muddy by nature, and they are confined to the inner shelf in modern settings.

(9) Distinguishing criteria of ancient hyperpycnites from turbidites or contourites are muddled. (10) After 65 years of research since Bates (AAPG Bulletin 37: 2119-2162, 1953), our understanding of hyperpycnal flows and their deposits is still incomplete and without clarity.
\end{abstract}

Keywords: Density plumes, Facies model, Hyperpycnites, Submarine fans, Tidal shear fronts, Ocean currents, Turbidity currents, Yellow River, Yangtze River

Correspondence: shanshanmugam@aol.com

Department of Earth and Environmental Sciences, The University of Texas at

Arlington, Arlington, TX 76019, USA 


\section{Introduction}

\subsection{The incentive}

The term "hyperpycnite" (i.e., deposits of hyperpycnal flows) was first introduced by Mulder et al. (2002) in an academic debate with me (Shanmugam 2002) on the origin of inverse grading by hyperpycnal flows. The following year, Mulder et al. (2003) published their review paper with the introduction of the genetic facies model of hyperpycnites. I have been an ardent critic of all genetic facies models. Examples are:

1) "Is the turbidite facies association scheme valid for interpreting ancient submarine fan environment?" (Shanmugam et al. 1985).

2) "The Bouma sequence and the turbidite mind set" (Shanmugam 1997).

3) "The tsunamite problem" (Shanmugam 2006b).

4) "The landslide problem" (Shanmugam 2015).

5) "Submarine fans: A critical retrospective (1950 -2015)" (Shanmugam 2016a).

6) "The contourite problem" (Shanmugam 2016b).

7) “The seismite problem" (Shanmugam 2016c).

In continuing this trend, it is only logical to contribute this paper — "The hyperpycnite problem".

\subsection{The history}

Forel $(1885,1892)$ first reported the phenomenon of density plumes in the Lake Geneva (Loc Léman), Switzerland (Fig. 1). In advocating a rational theory for delta formation, Bates (1953) suggested three types: (1) hypopycnal plume for floating river water that has lower density than basin water (Fig. 2a); (2) homopycnal plume for mixing river water that has equal density as basin water (Fig. 2b); and (3) hyperpycnal plume for sinking river water that has higher density than basin water (Fig. 2c). Mulder et al. (2003) expanded the applicability of the concept of hyperpycnal plumes from shallow water (deltaic) to deep-water (continental slope and abyssal plain) environments. In this new development, hyperpycnal flows are considered analogous to turbidity currents in many respects (Mulder et al. 2003; Steel et al. 2016; Zavala and Arcuri 2016).

During the past four decades, there has been an accelerated effort to understand these density plumes through (1) observational and/or interpretational (Arnau et al. 2004; Bhattacharya and MacEachern 2009; Collins et al. 2017; Gihm and Hwang 2016; Johnson et al. 2001; Lewis et al. 2018; Luo et al. 2017; Milliman et al. 2007; Mulder et al. 2003; Mutti et al. 1996; Ogston et al. 2000; Pan et al. 2017; Petter and Steel 2006; Pierce 2012; Puig et al. 2014; Schillereff et al. 2014; Shanmugam 2016a, 2018a, 2018b, 2018c; Soyinka and Slatt 2008; Steel et al. 2016, 2018; Sun et al. 2016; Talling 2014; Warrick et al. 2013; Wilson and Schieber 2014, 2017; Wright et al. 1986, 1988; Yang et al. 2017a; Zavala and Arcuri 2016; Zavala and Pan 2018; Zavala et al. 2006; among others), (2) experimental (Kostic and Parker 2003; Kostic et al. 2002; Lamb and Mohrig 2009; Lamb et al. 2010; Parsons et al. 2001), and (3) numerical (Chen et al. 2013; Kassem and

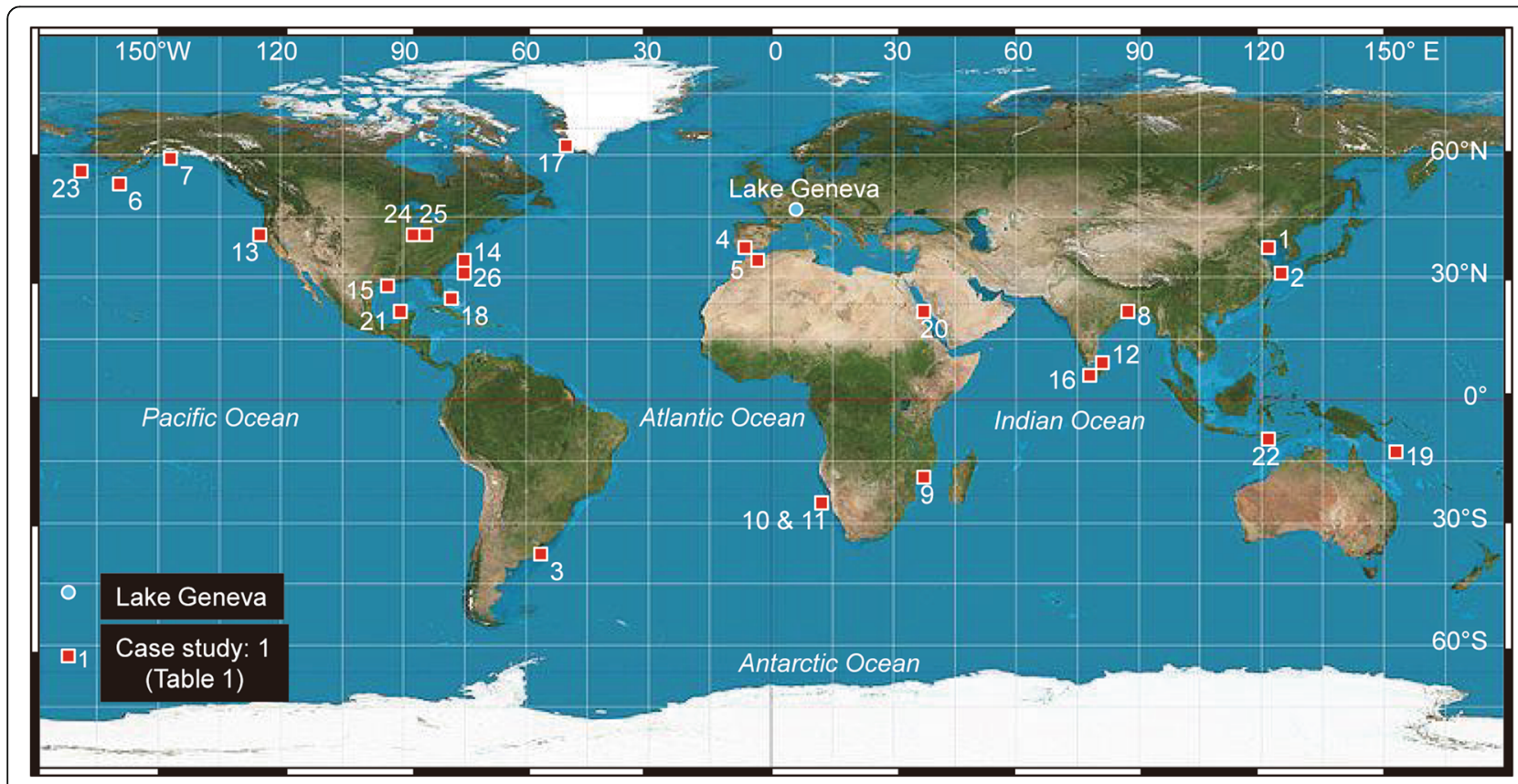

Fig. 1 Location map of 26 case studies of marine and lacustrine environments (Table 1). Forel (1885, 1892) first reported the phenomenon of density plumes in the Lake Geneva, which is considered as the birthplace of concepts related to density plumes 


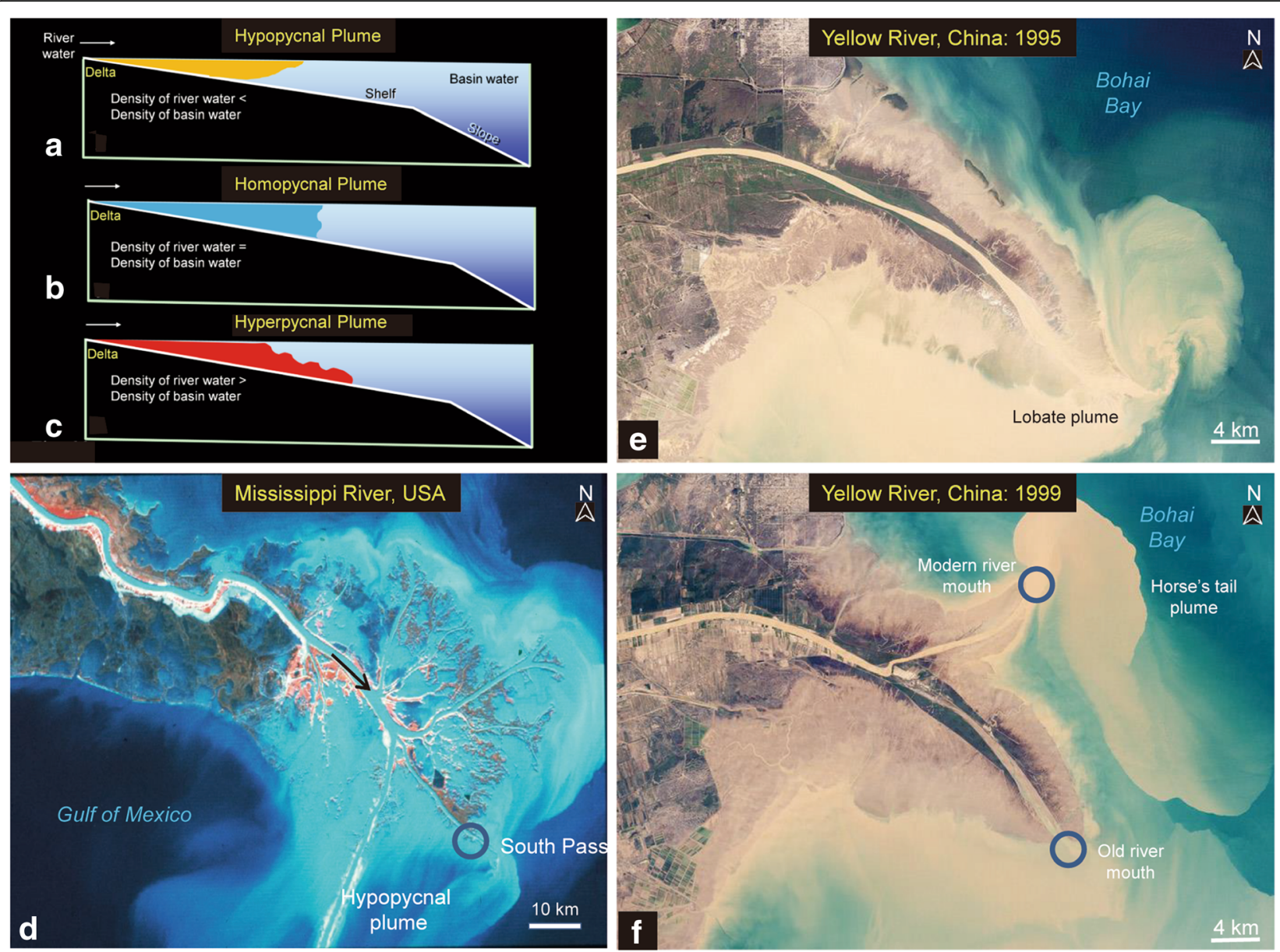

Fig. 2 Concepts and examples of density plumes. $\mathbf{a}, \mathbf{b}$, and $\mathbf{c}$ Schematic diagrams showing three types of density variations in riverine plumes in deltaic environments based on concepts of Bates (1953). a Hypopycnal plume in which density of river water is less than density of basin water; b Homopycnal plume in which density of river water is equal to density of basin water; c Hyperpycnal plume in which density of river water is greater than density of basin water. Figure from Shanmugam (2012) with permission from Elsevier Handbook of Petroleum Exploration and Production. License Number: 4259411120776. License Date: December 31, 2017; d Image of the Mississippi River showing well-developed floating hypopycnal plumes. Note "deflecting" plumes. Black arrow shows river course for the South Pass (Walker et al., 1993). Circle shows river mouth. See Coleman and Prior (1982) for river-dominated deltaic facies model. Image credit: NASA; e Satellite image of the Yellow River showing well-developed lobate plume at the old river mouth. Image credit: NASA Earth Observatory. https://earthobservatory.nasa.gov/Features/WorldOfChange/yellow_river.php?all=y; f Satellite image of the Yellow River showing horse's tail plume at the modern river mouth that was initiated in 1996. Two circles show old and modern river mouths. Image credit: NASA Earth Observatory. https://earthobservatory.nasa.gov/Features/WorldOfChange/yellow_river.php?all=y

Imran 2001; Khan et al. 2005; Kostic and Parker 2003; Morales de Luna et al. 2017; Qiao et al. 2008; Wang and Wang 2010; Wang et al. 2017; among others) studies.

\subsection{The problem}

Despite popular claims that (1) river flows transform into turbidity currents at plunge points near the shoreline (Kostic et al. 2002; Lamb et al. 2010), (2) hyperpycnal flows have the power to erode the seafloor and cause submarine canyons (Lamb et al. 2010), (3) hyperpycnal flows develop an unique vertical sequence (i.e., facies model) (Mulder et al. 2003), and, (4) hyperpycnal flows are efficient in transporting sand across the shelf and can deliver sediments into the deep sea for developing submarine fans (Zavala and Arcuri 2016), our understanding of hyperpycnal flows and their deposits, in particular, in deep-water settings (i.e., seaward of the shelf-slope break at about $200 \mathrm{~m}$ water depth, Fig. 3), is highly speculative.

Specific issues are:

1) There is not a single documented case of hyperpycnal flow, which is transporting sand across the continental shelf, and supplying sand beyond the modern shelf break (Fig. 3).

2) Thus far, the emphasis has been solely on rivermouth hyperpycnal flows (Mulder et al. 2003), thus ignoring density plumes in other environments, 


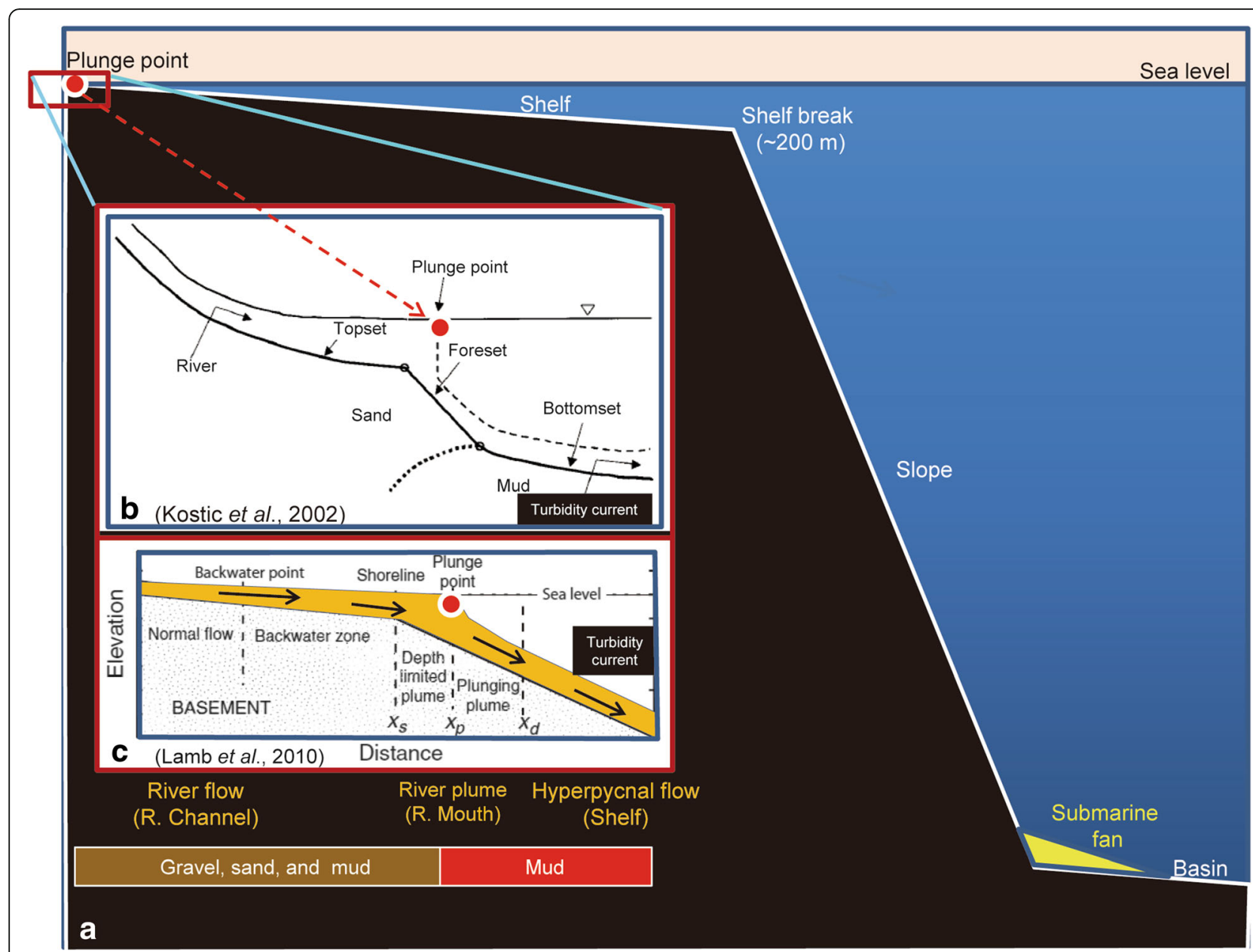

Fig. 3 Continental margin and flume experiments. a Conceptual diagram of a continetal margin showing relative positions of plunge point (red filled circle) at river mouth and submarine fan at base-of-slope. Average shelf width $=80 \mathrm{~km}$. Maximum shelf width = 1,500 km; b Schematic diagram, based on flume experiments conducted using fresh water as standing body, showing transformation of river current into turbidity current at plunge point (red filled circle). Note that this experiment using fresh water is applicable to fresh water lakes, but not to marine settings (sea or ocean). From Kostic et al. (2002) with additional labels; c Schematic diagram with backwater zone showing transformation of river plume into turbidity currents at plunge point (red filled circle). Note the close similarity between B and C on the initiation of turbidity currents at plunge point. In this study, the term "hyperpycnal flow" is used for flows seaward of the plunge point, instead of turbidity current (see text). From Lamb et al. (2010) with additional symbols

such as open marine settings, far away from the shoreline.

3) Despite their common occurrence, density plumes triggered by tidal currents, glacial meltwater, eolian dust, volcanic explosion, cyclones, tsunamis, upwelling, etc. are largely ignored from sedimentological investigations.

4) Specifically, there are fundamental problems associated with the concept of hyperpycnal flows in terms of fluid dynamics, depositional mechanisms, sedimentary structures, etc., which generated a lively debate (Mulder et al. 2002; Shanmugam 2002).

5) Finally, hyperpycnite facies models have implications for the petroleum industry for predicting sandy reservoirs in deep-water petroleum exploration and exploitation. For example, Yang et al. (2017a, p. 115) in their article published in the AAPG Bulletin stated that "The lacustrine hyperpycnites of the Yanchang Formation have important implications for unconventional petroleum exploitation". Shanmugam (2018a) discussed this study in terms of inherent problems with data, documentation, and facies model.

\subsection{The objective}

In addressing the above listed problems, the primary purpose of this article is to rigorously evaluate the merits of various claims on hyperpycnal flows and related facies models. This evaluation is based on 26 case studies (Fig. 1; Table 1). Each case study is used in identifying problem areas. In particular, the Yellow River in China is used as the prime example because of its historical significance 


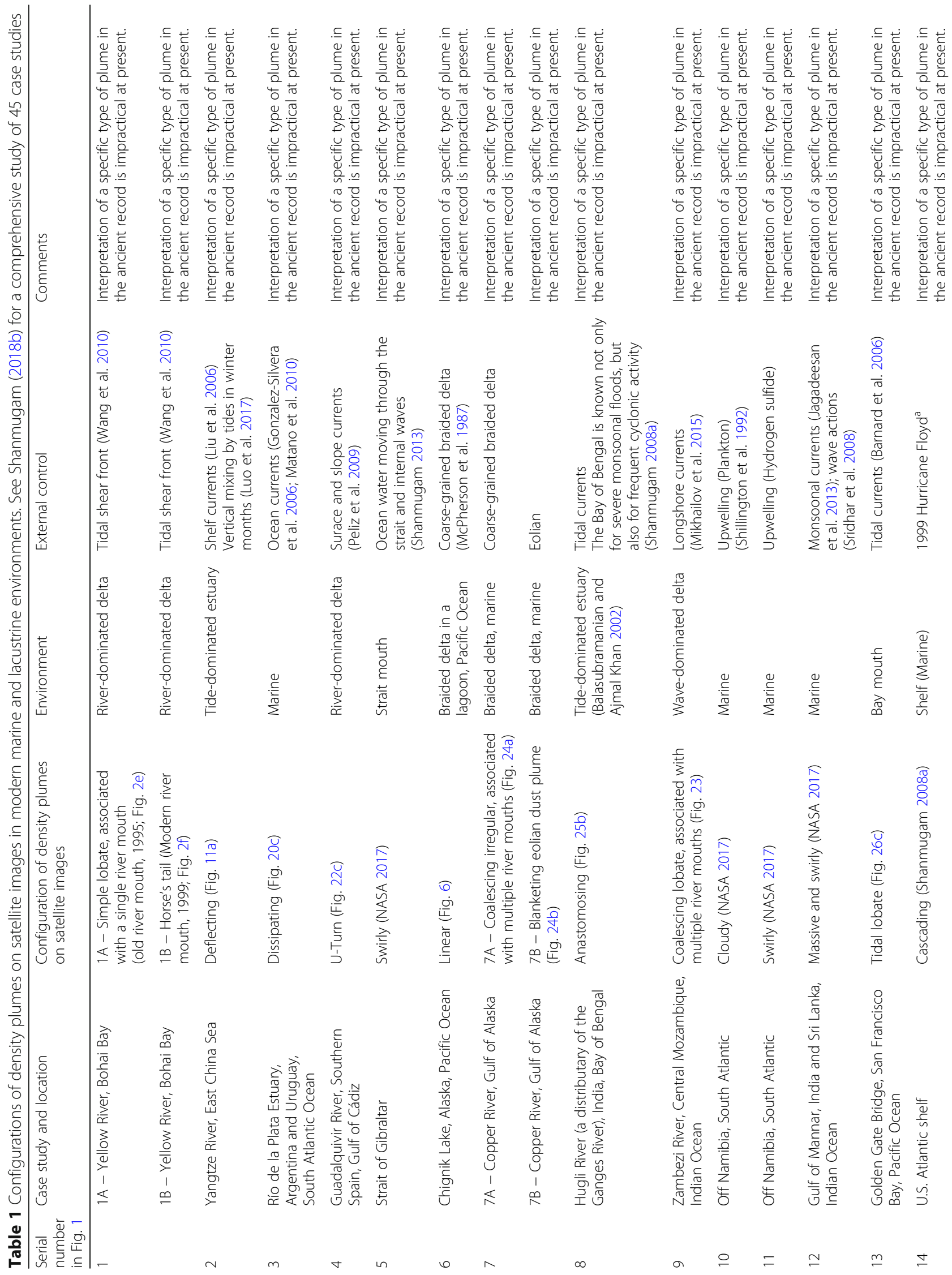




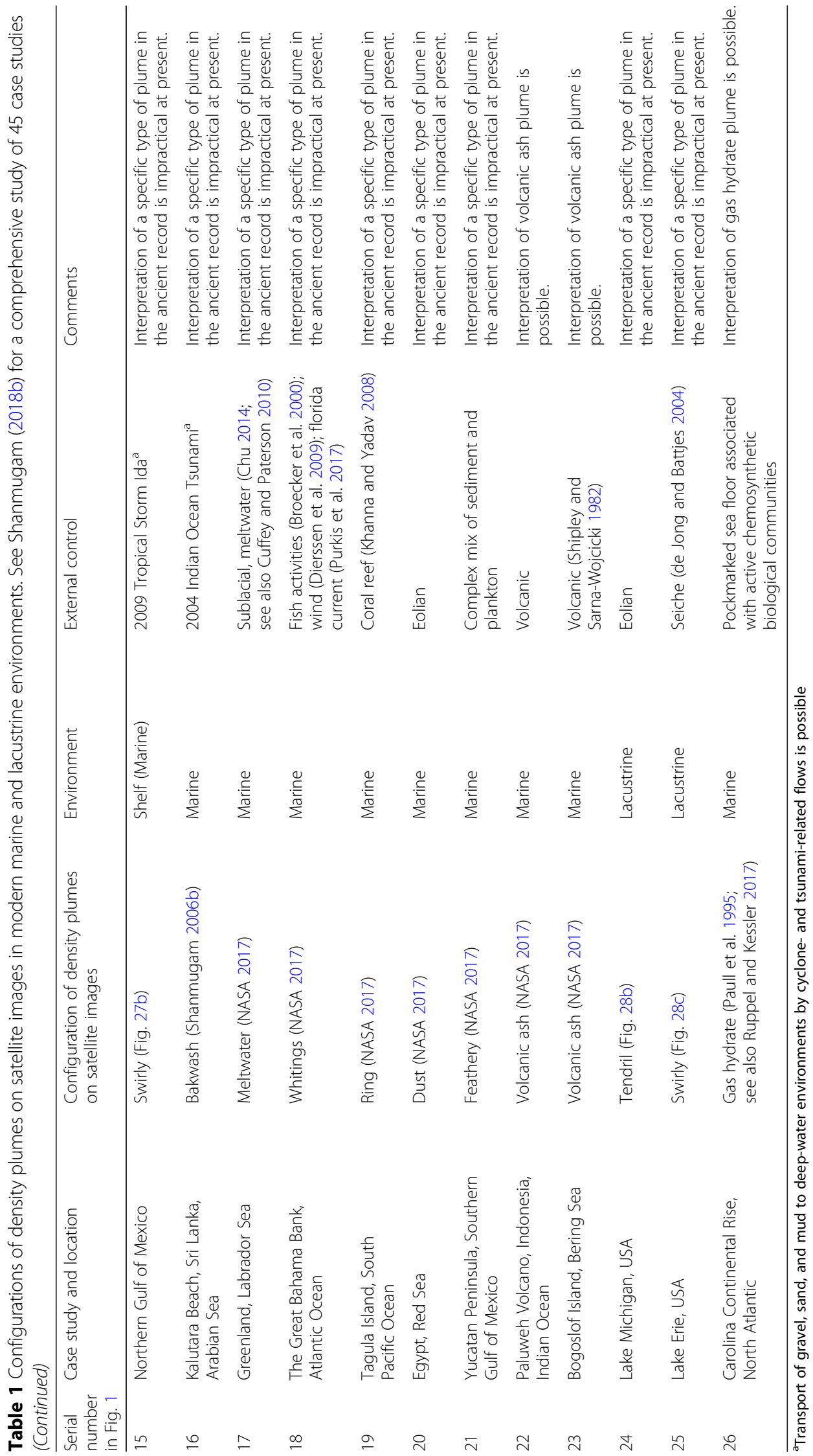


(Milliman and Meade 1983) and its data-rich environments (Wright et al. 1986). This paper is organized into the following topics: (1) basic concepts, (2) the Yellow River, (3) the Yangtze River, (4) external controls, (5) recognition of ancient hyperpycnites, (6) submarine fans, (7) submarine canyons, and (8) configurations of density plumes. The ultimate goal here is to identify problem areas and to alert students of challenges in their future research and to identify opportunities for future research.

\section{Basic concepts}

In this review, which covers multiple disciplines (e.g., process sedimentology, physical oceanography, meteorology, hydraulic engineering, etc.), it is necessary to establish at the outset some basic concepts and related nomenclatures.

\subsection{Hyperpycnite}

As mentioned at the outset, the term "hyperpycnite" was introduced by Mulder et al. (2002) in an academic debate with me (Shanmugam 2002) on the origin of inverse grading by hyperpycnal flows. Mulder et al. (2002) attempted to differentiate "hyperpycnites" deposited by hyperpycnal turbidity currents from "classic turbidites" deposited from failure-related turbidity currents. The problem is that triggering mechanisms of turbidity currents (or any other process) cannot be determined from the depositional record (Shanmugam 2015, 2016a, 2016b, 2016c).

\subsection{Continental margin}

A basic conceptual framework is used in which a river mouth is located near the shoreline, whereas a submarine fan is located at the base of the continental slope, separated by a wide continental shelf (Fig. 3a). In order for river plumes to act as hyperpycnal flows and deliver sediment to the deep sea for developing submarine fans (Zavala and Arcuri 2016), hyperpycnal flows must travel 10s to 100s of kilometers across the shelf from their point of origin.

\subsection{Plunge point}

The term "plunge point" is used for both "plunging waves" and "plunging rivers". According to the Glossary of Coastal Terminology (1998), a plunging wave is defined as the point at which the wave curls over and falls. According to Assireu et al. (2011), for plunging rivers, the plunge point is the main mixing point between river and epilimnetic reservoir. In other words, the point at which sediment-laden river flow plunges down into a standing body of water, be it a lake, a reservoir, or a sea. Plunging occurs very close to the shoreline in shallow water (Fig. 3b). In the Yellow River in China, for example, the plunge point occurs at $5 \mathrm{~m}$ of depth in the
Bohai Bay (Wright et al. 1986). When a river flow crosses the plunge point at the river mouth, it transforms into a river plume of various densities, which include hyperpycnal plumes (Fig. 2c). At the plunge point, the river flow moves from a momentum-dominated type to a buoyancy-dominated type and marks the transition of an inflow to an underflow (Dallimore et al. 2004).

At the plunge point, the river has already dropped its coarse fractions (gravel and sand) upstream as delta-plain facies. The remaining fine fractions in muddy suspension move forward on the open shelf as hyperpycnal flows. Plunging would occur only if suspended sediment concentration in the river exceeds the critical value of $35-45 \mathrm{~kg} \cdot \mathrm{m}^{-3}$ (Imran and Syvitski 2000; see Mulder et al. 2003 for differences in values between equatorial and subpolar rivers).

\subsection{Plume versus flow}

In practice, there is a tendency to equate the term "flow" with "plume". These two terms are not one and not the same. In hydrodynamics, the term plume describes a condition when a column of one fluid moves through another fluid. To accommodate natural variability in plume types, a broad definition of plume is adopted in this article. Accordingly, a plume is a fluid enriched in sediment, ash, biological or chemical matter that enters another fluid. As it would be demonstrated later, there is a multitude of plume types in nature. Among them, the river plume is the most popular. NOAA Fisheries Glossary (2006, p. 42) defines a River Plume as "Turbid freshwater flowing from land and generally in the distal part of a river (mouth) outside the bounds of an estuary or river channel".

However, the term "flow" is used for a continuous, irreversible deformation of sediment-water mixture that occurs in response to applied shear stress, which is gravity in most cases (Pierson and Costa 1987, p. 2). Not all plumes are flows. For example, floating hypopycnal plumes are not driven by gravity (Fig. 2a). However, both terms "flow" and "plume" are applicable to hypepycnal type. The other practice is to employ terms "overflow", "interflow", and "underflow" for hypopycnal, homopycnal, and hyperpycnal plumes, respectively. Again, the term flow is not appropriate for hypopycnal plume that is unaffected by gravity.

\subsection{Types of river-mouth flows}

In discussing river-mouth processes, geologists, geophysicists, and hydraulic engineers use process terms to represent hyperpycnal flows that are not consistent in meaning with each other, such as single-layer and multi-layer hyperpycnal flows (Fig. 4; see Section 3.5). For example, the following concepts and terms are used in the literature: 


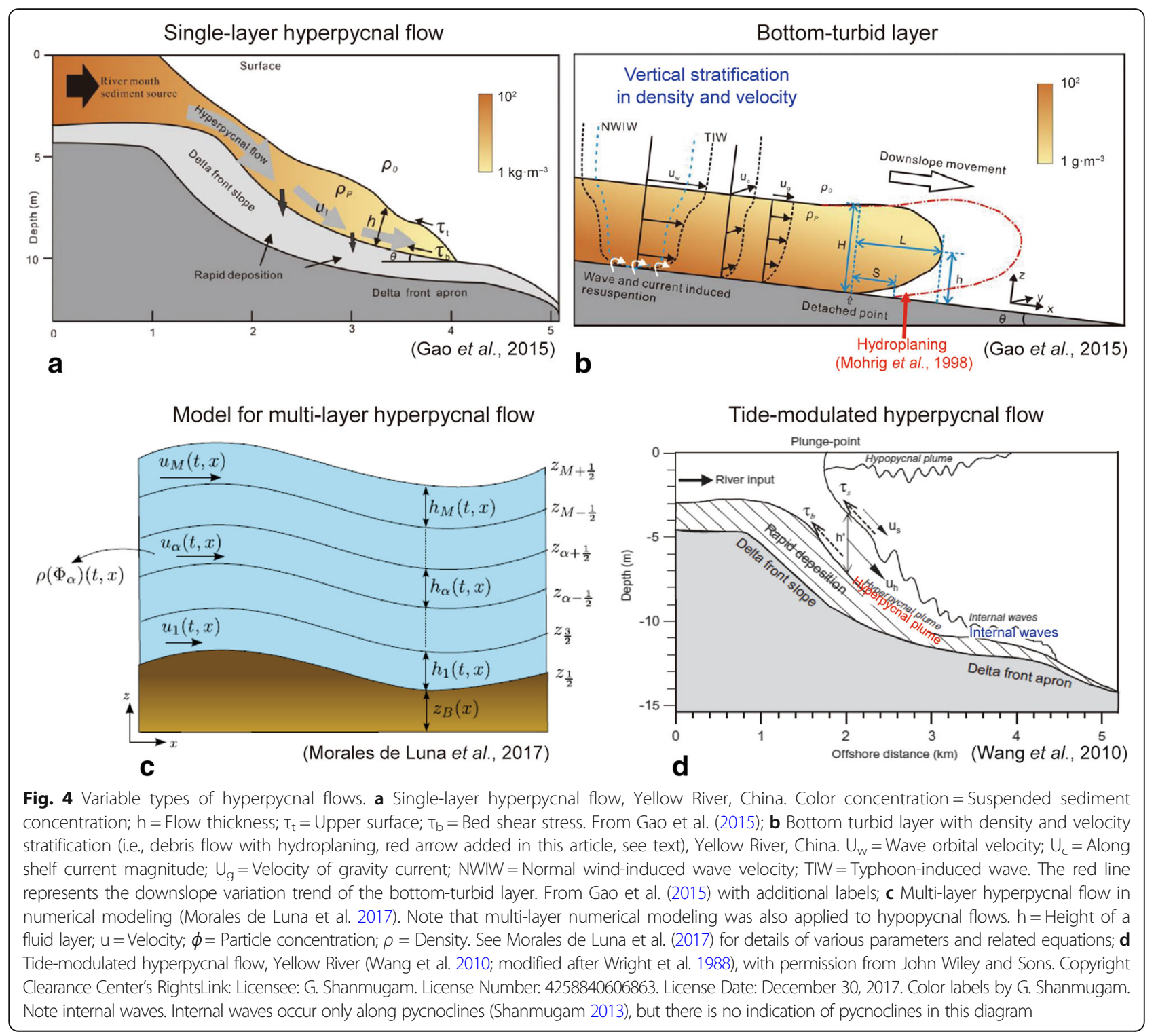

1) Density flow (Parker and Toniolo 2007).

2) Underflow (Wright et al. 1986).

3) Hyperpycnal flow (Bates 1953; Moore 1966).

4) Hyperpycnal underflow (Wright et al. 1986).

5) Hyperconcentrated flow (van Maren et al. 2009).

6) Low-density hyperpycnal plume (Wright et al. 1986).

7) High-density hyperpycnal plume (Wright et al. 1986).

8) High-turbid mass flow (Fan et al. 2006).

9) Supercritical hyperpycnal flow (Yang et al. 2017b).

10) Tide-modulated hyperpycnal flow (Fig. 4d) (Wang et al. 2010).

11) Cyclone-induced hyperpycnal turbidity current (Liu et al. 2012).

12) Buoyancy-dominated flow (Dallimore et al. 2004).
13) Hyperpycnal turbidity current (Plink-Björklund and Steel 2004).

14) Turbidity front (Framiňan and Brown 1996).

15) Turbidity current (Kostic and Parker 2003; Kostic et al. 2002; Lamb et al. 2010; Wright et al. 1986; Zavala and Arcuri 2016).

16) Multi-layer hyperpycnal flows (Morales de Luna et al. 2017).

These 16 river-mouth processes, some with superfluous meanings, do not have a unifying principle of fluid dynamics as their foundation. It is confusing when geologists manufacture a plethora of superfluous names for a single process. In this tradition, the concept of 
"high-density turbidity currents" is the leader with 34 synonymous terms (Shanmugam 2006a).

\subsection{River currents versus turbidity currents}

The practice of equating subaqueous turbidity currents with subaerial river currents (Chikita 1989) is confusing for many reasons (Table 2). River currents and turbidity currents are fundamentally different, although both are turbulent in state (Middleton 1993). River currents are low in suspended sediment $(1 \%-5 \%$ by volume; Galay 1987), whereas turbidity currents (i.e., low-density turbidity currents) are relatively high in suspended sediment ( $1 \%-23 \%$ by volume; Middleton 1993), although both currents are considered to be Newtonian in rheology (Table 2). River currents are fluid-gravity flows, whereas turbidity currents are sediment-gravity flows (Middleton 1993), which is the most important distinction. To reiterate, a turbidity current is a sediment flow with Newtonian theology and turbulent state in which sediment is supported by fluid turbulence and from which deposition occurs through suspension settling (Dott 1963; Middleton and Hampton 1973; Sanders 1965; Shanmugam 1996, 2006a; Talling et al. 2012). In addition, according to Bagnold (1962), typical turbidity currents can function as truly turbulent suspensions only when their sediment concentration by volume is below 9\%. Therefore, river currents should not be equated with turbidity currents.

In the 1930s, density currents (Daly 1936) and turbidity currents were considered to be one and the same. Since then, the domain of turbidity currents went through a remarkable period of revolution and evolution (Shanmugam 2016a). After 80 years of research, we have come full circle. Today, we once again consider density currents and turbidity currents to be one and the same. For example, Parker and Toniolo (2007, p. 690) defined a turbidity current as follows: "When the density difference is mediated by the presence of suspended mud in the water

Table 2 Comparison of subaerial river currents and subaqueous turbidity currents (partly based on Shanmugam 1997)

\begin{tabular}{|c|c|c|}
\hline Features & River currents & Turbidity currents \\
\hline Ambient fluid & Air & Water \\
\hline Rheology of fluid & Newtonian & Newtonian \\
\hline $\begin{array}{l}\text { Type of gravity } \\
\text { influence }\end{array}$ & Fluid gravity & Sediment gravity \\
\hline Nature of flow & $\begin{array}{l}\text { Uniform\steady } \\
\text { and continuous }\end{array}$ & $\begin{array}{l}\text { Uniformlunsteady } \\
\text { and episodic }\end{array}$ \\
\hline $\begin{array}{l}\text { Sediment } \\
\text { concentration }\end{array}$ & $\begin{array}{l}\text { Low ( } 1 \%-5 \% \\
\text { by volume) }\end{array}$ & $\begin{array}{l}\text { High ( } 1 \%-23 \% \\
\text { by volume) }\end{array}$ \\
\hline $\begin{array}{l}\text { Dominant transport } \\
\text { of sand }\end{array}$ & Bed load & Suspended load \\
\hline Dominant structures & Cross bedding & $\begin{array}{l}\text { Normally graded } \\
\text { bedding }\end{array}$ \\
\hline
\end{tabular}

column of the river, the resulting underflow is termed a turbidity current". However, the distinction is that all turbidity currents are density currents, but not all density currents are turbidity currents (e.g., thermohaline-density driven bottom currents or "contour currents" (Hollister 1967)). It should be reiterated that all hyperpycnal plumes are density plumes, but not all density plumes are hyperpycnal plumes (e.g., hypopycnal and homopycnal plumes). This confusion can be easily avoided by simply adhering to the established concepts available in sedimentologic literature (Bagnold 1962; Dott 1963; Middleton and Hampton 1973; Sanders 1965; Shanmugam 1996, 2006a, 2018c; Talling et al. 2012).

The first step in evaluating density plumes is to distinguish a "plume" from a "flow" and to differentiate a "river current" from a "turbidity current".

\subsection{Transformation of river currents into turbidity currents}

Based on experimental (Kostic et al. 2002) and numerical simulation, Kostic and Parker (2003) suggested that river currents transform into turbidity currents at the plunge point (Fig. 3b). Because Kostic et al. (2002) used fresh water in their experiment as a standing body of water, care must be exercised in applying the experimental results (i.e., initiation of turbidity currents at the plunge point) to marine settings (sea or ocean), which is the focus of this article. There are concerns with the experimental/numerical model.

1) Average density of sea water at the surface is $1.025 \mathrm{~kg} \cdot \mathrm{L}^{-1}$, whereas that of fresh water is 1.0 $\mathrm{kg} \cdot \mathrm{L}^{-1}$ at $4{ }^{\circ} \mathrm{C}\left(39^{\circ} \mathrm{F}\right)$. This density difference is crucial for understanding the generation of a density flow, such as the hyperpycnal flow.

2) No one has documented the transformation of river currents into turbidity currents at a shallow plunge point in modern marine environments.

3) These river-flow triggered turbidity currents in laboratory experiments, yet to be documented in modern marine settings, are muddy flows. Therefore, they are of no consequence in transporting sand and gravel across the continental shelf and deliver the sediment into the deep sea for developing submarine fans.

4) Importantly, not all density flows are turbidity currents. For example, although both debris flows and turbidity currents are considered to be density flows, each one can be distinguished from the other by fluid rheology and flow turbulence (Dott 1963; Sanders 1965). Such a distinction is not considered in defining hyperpycnal flows. Hyperpycnal flows are defined solely on the basis of fluid density. Therefore, it is misleading to equate turbidity 
currents with hyperpycnal flows (Kostic et al. 2002; Lamb et al. 2010; Steel et al. 2016; Zavala and Arcuri 2016).

5) Lamb et al. (2010) applied the numerical model in their experimental model for hyperpycnal flows with emphasis on marine environments (Fig. 3c). It is worth noting that Lamb et al. (2010) also used fresh tap water in their experiments for standing body of water. Therefore, their experimental results on hyperpycnal flows are applicable only to freshwater lakes, but not to marine bodies of water (sea or ocean). In order for the experimental/numerical model to be applicable to marine settings, the model needs to be tested in the real world by documenting the transformation of river currents into turbidity currents in marine settings like the Yellow River in China (Wright et al. 1986) that plunges into the Bohai Bay (see Section 3).

\subsection{Fine-grained deltas versus coarse-grained deltas}

In the geologic and engineering literature, the focus of discussion on hyperpycnal flows is centered on fine-grained deltas or common deltas. McPherson et al. (1987) distinguished fine-grained deltas from coarse-grained deltas (Fig. 5). The importance here is that braid (braided) deltas, kind of coarse-grained deltas, are typical of high-gradient settings with high-velocity river flows (Fig. 5). Because these braided rivers plunge into a standing body of water with multiple entry points, separated by braided bars, these rivers develop linear hyperpycnal plumes (Fig. 6). Distinguishing linear types is important because braid deltas are known to develop various types of sediment flows, including debris flows, in the subaqueous delta fronts (McPherson et al. 1987). At present, coarse-grained deltas are totally ignored in studying hyperpycnal flows. As a consequence, all published examples of hyperpycnal lows are from fine-grained deltas, such as the Yellow River delta in China.

\section{The Yellow River, China}

The Yellow River, which is the second largest river in China, is regarded as the world's largest contributor of fluvial sediment load to the ocean (Yu et al. 2011). Historically, it contributed a sediment load of nearly 100 million tons per year (Milliman 2001). The Yellow River's average annual suspended-load concentration of $25,000 \mathrm{mg} \cdot \mathrm{L}^{-1}$ and flood stage concentration of 220,000 $\mathrm{mg} \cdot \mathrm{L}^{-1}$ are the largest in the world by 1983 (Milliman and Meade 1983). In September 1995, a cruise was undertaken to detect hyperpycnal flows off the Yellow River mouth (Wang et al. 2010). During the cruise (18-19 September), daily suspended sediment

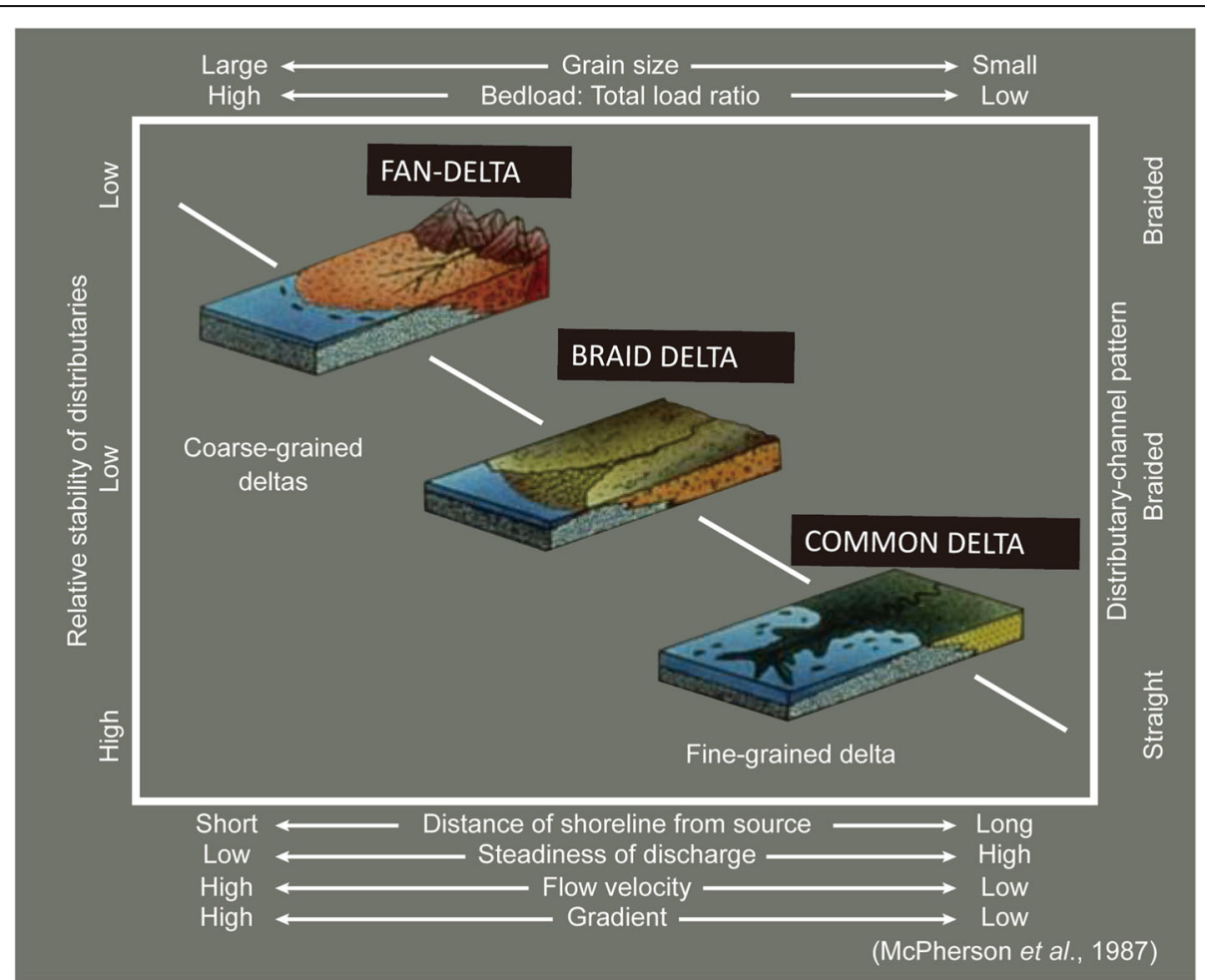

Fig. 5 A comparison of coarse-grained deltas and fine-grained deltas based on distributary-channel patterns and stability, sediment load and size, stream gradient and velocity, and other properties. Fan-deltas and braiddeltas are coarse-grained deltas that contrast in shape, size, and composition with fine-grained deltas (common deltas). From McPherson et al. (1987) 


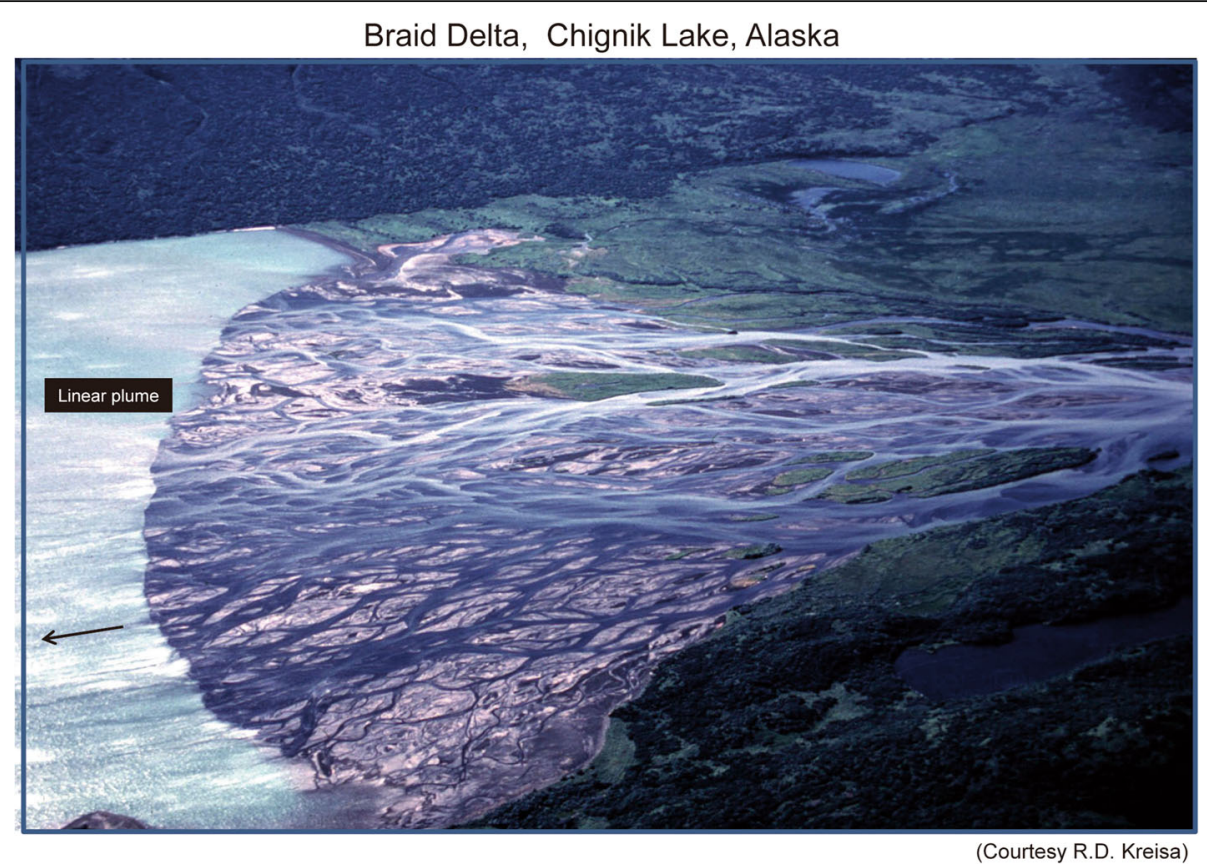

Fig. 6 Braid delta from Chignik Lake, southeastern coast, Alaska, showing multiple entry points with shooting "linear" hyperpycnal plumes into a standing body of water. Photo courtesy of R.D. Kreisa. From McPherson et al. (1987)

concentration (SSC) was close to $50 \mathrm{~kg} \cdot \mathrm{m}^{-3}$ and daily average stream discharge was $2000 \mathrm{~m}^{3} \cdot \mathrm{s}^{-1}$. The critical concentration of suspended sediment ranges from 36 $\mathrm{kg} \cdot \mathrm{m}^{-3}$ to $43 \mathrm{~kg} \cdot \mathrm{m}^{-3}$ for coastal waters depending on local salinity, temperature and climatic conditions (Mulder and Syvitski 1995).

The Yellow River drains through that part of the world that is covered by extensive soft and easily erodible, wind-transported, loess deposits in China (Fig. 7a). The loess is intensively eroded during the monsoon rains, generating unusual suspended particle concentration at the Yellow River mouth, which generates hyperpycnal flows (Wright et al. 1986, 1990). Because the Yellow River is an ideal river for generating hyperpycnal flows, I focus attention on this river, which is rich in empirical data (Fig. 7).

\subsection{Delta versus estuary}

One confusing aspect of the Yellow River literature is that some authors refer to the river mouth as a "delta" (Gao et al. 2014; Wang et al. 2017; among many others), whereas others refer to it as an "estuary" (e.g., Hu et al. 1998; Wang and Wang 2010). The distinction between a delta and an estuary is not trivial (Dalrymple 1992; Dalrymple et al. 1992; Shanmugam et al. 2000). The Yellow River cannot be both a delta and an estuary at the same time. According to the Oxford Dictionaries (2018), the term "estuary" is derived from a mid sixteenth century Latin word "aestuarium" meaning tidal part of a shore ('estus' = 'tide').
Fairbridge (1980) defined an estuary as "an inlet of the sea reaching into a river valley as far as the upper limit of tidal rise". Whether the Yellow River is a delta or an estuary is important here because estuaries are not ideal candidates for transporting hyperpycnite sediments offshore. This is because of ebb and flood tides and their bidirectional currents. In this study, the Yellow River is considered to be a river-dominated delta with tidal influence.

\subsection{Bathymetry}

Wang et al. (2017) obtained bathymetric data for the Yellow River and the western Laizhou Bay for the years 1976, 1980, 1985, 1991, 1996 and 2012, and presented maps with a spatial resolution of 300-500 m (Fig. 8). Maps show a clear change in bathymetry in front of the river mouth because of the change in river course. The change in river course from an abandoned south-flowing old river (1976-1996) to the modern north-flowing river was illustrated by Wang et al. (2015, their Figs. 1 and 2e-f). Changes in river-mouth bathymetry are a reflection of chages in river courses and related types of sediment plumes.

\subsection{River-mouth processes}

Wright et al. (1986) were the first authors to investigate hyperpycnal flows at the Yellow River mouth. Because the turbidite paradigm was in full force during the 1970s and 1980s, Wright et al. (1986) emphasized the 

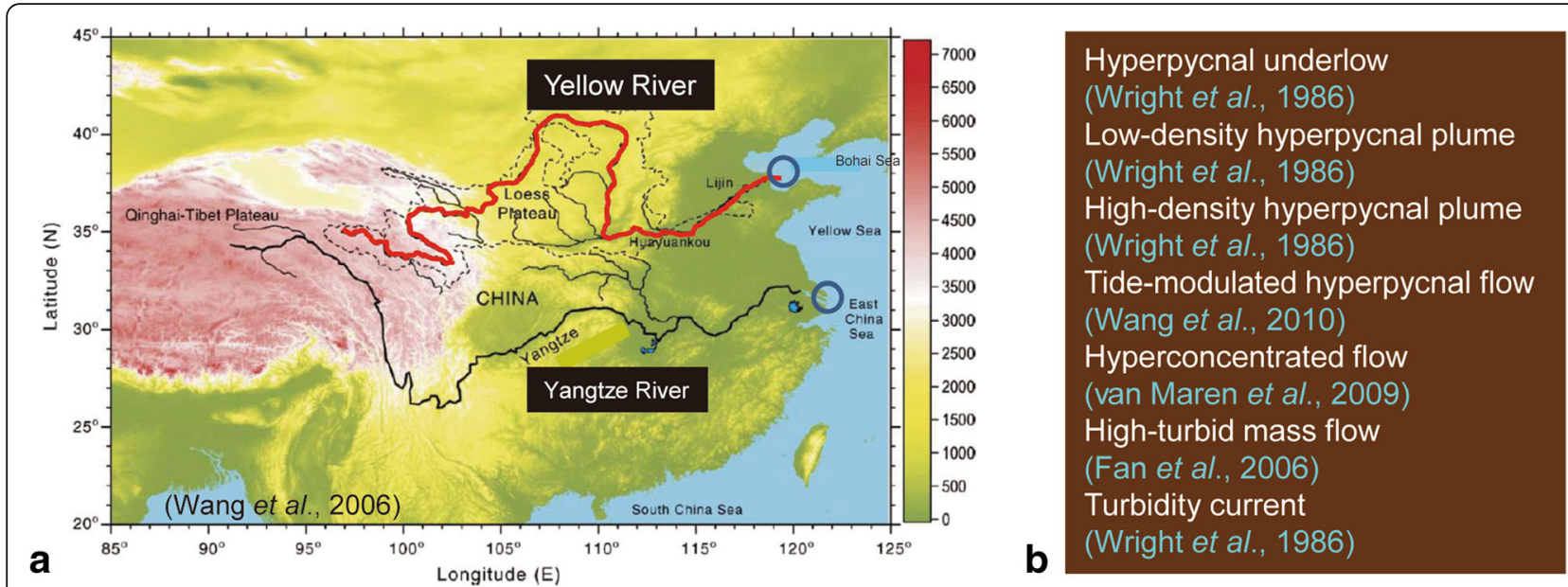

\section{Wright et al. (1986):}

Plunge point depth: $5 \mathrm{~m}$

Suspended sediment concentrations: 25 to $220 \mathrm{~g} \cdot \mathrm{L}^{-1}$

Average annual suspended-load concentration: $25,000 \mathrm{mg} \cdot \mathrm{L}^{-1}$

Flood stage concentration: $220,000 \mathrm{mg}^{\mathrm{L}-}$

Milliman (2001):

Annual contribution of sediment to ocean: $100,000,000$ tons

Wang et al. (2008):

Data period: 1977-2002

Maximum monthly discharge in August: $\sim 1500 \mathrm{~m}^{3} \cdot \mathrm{s}^{-1}$

Minimum monthly discharge in April: $\sim 200 \mathrm{~m}^{3} \cdot \mathrm{s}^{-1}$

Bi et al. (2010):

Data period: August 8-13, 2003

Normal discharge: $200 \mathrm{~m}^{3} \cdot \mathrm{s}^{-1}$

Tidal range: $1.5-2.0 \mathrm{~m}$

Mean tidal current velocity: $0.5-1.0 \mathrm{~m} \cdot \mathrm{s}^{-1}$

Maximum ebb-tidal current velocity: $67.4 \mathrm{~cm} \cdot \mathrm{s}^{-1}$

C

Maximum flood-tidal current velocity: $44.9 \mathrm{~cm} \cdot \mathrm{s}^{-1}$
Li et al. (2001) and Wang et al. (2007, 2017):

Tidal shear front functions as sediment barrier (Fig. 9A)

Wang et al. (2010) (Fig. 9A):

Data period: September 18-19, 1995

Daily suspended sediment concentration: $\sim 50 \mathrm{~kg} \cdot \mathrm{m}^{-3}$

Daily average stream discharge: $2000 \mathrm{~m}^{3} \cdot \mathrm{s}^{-1}$

Velocity of neap tidal currents: $\sim 1.0 \mathrm{~m} \cdot \mathrm{s}^{-1}$

Velocity of spring tidal currents: $\sim 2 \cdot 0 \mathrm{~m} \cdot \mathrm{s}^{-1}$

Tidal shear front limits seaward sediment transport

Wang et al. (2015):

Old river mouth:1976-1996 (Fig. 2E)

Modern river mouth: 1996-Present (Fig. 2F)

Tidal range off the river mouth: $0.5-1.1 \mathrm{~m}$

Maximum tidal current velocity: $1.4 \mathrm{~m} \cdot \mathrm{s}^{-1}$

Tidal current speeds decreased continually

off the old river mouth

Tidal current speeds increased continually

off the modern river mouth

Fig. 7 Data from the Yellow River. a The course of the Yellow River draining the loess plateau before entering the Bohai Bay. Note river mouth is highlighted by blue open circle. Note Yangtze River mouth (blue curcle) in the East China Sea. Image from Wang et al. (2006), with permission from Elsevier. Copyright Clearance Center's RightsLink: Licensee: G. Shanmugam. License Number: 4258880251701. License Date: December 30, 2017. Additional labels by G. Shanmugam; b Flow types and their nomenclature used for the Yellow River; c Relevant data of the Yellow River; $\mathbf{d}$ Empirical and numerical data on tidal shear front and on tidal currents for the Yellow River. See Bi et al. (2010) and Wang et al. (2008)

similarity between hyperpycnal flows and turbidity currents. As discussed earlier, turbidity currents are defined on the basis of fluid rheology, flow state, and sediment concentration, whereas hyperpycnal flows are defined solely on fluid density.

The following is a compilation of types of flows that have been used for the Yellow River.

1) Hyperpycnal underflow (Wright et al. 1986).

2) Low-density hyperpycnal plume (Wright et al. 1986).

3) High-density hyperpycnal plume (Wright et al. 1986).

4) Tide-modulated hyperpycnal flow (Wang et al. 2010).

5) Hyperconcentrated flow (van Maren et al. 2009).

6) High-turbid mass flow (Fan et al. 2006).

7) Turbidity current (Wright et al. 1986).
Clearly, there is no consistency in term of fluid dynamics. From a practical point of view, none of these publications discusses the depositional characteristics of various types of hyperpycnal flows.

\subsection{Bottom-turbid layers}

Wright et al. (2001) suggested the influence of ambient currents and waves on gravity-driven sediment flows, which are different from hyperpycnal flows. In this context, Gao et al. (2015) suggested that the Yellow River has undergone a regime shift in response to resuspension induced by tidal currents and waves. This shift has presumably resulted in the replacement of hyperpycnal flows by bottom-turbid layers. The difference between the two is that hyperpycnal flows behave as a single 


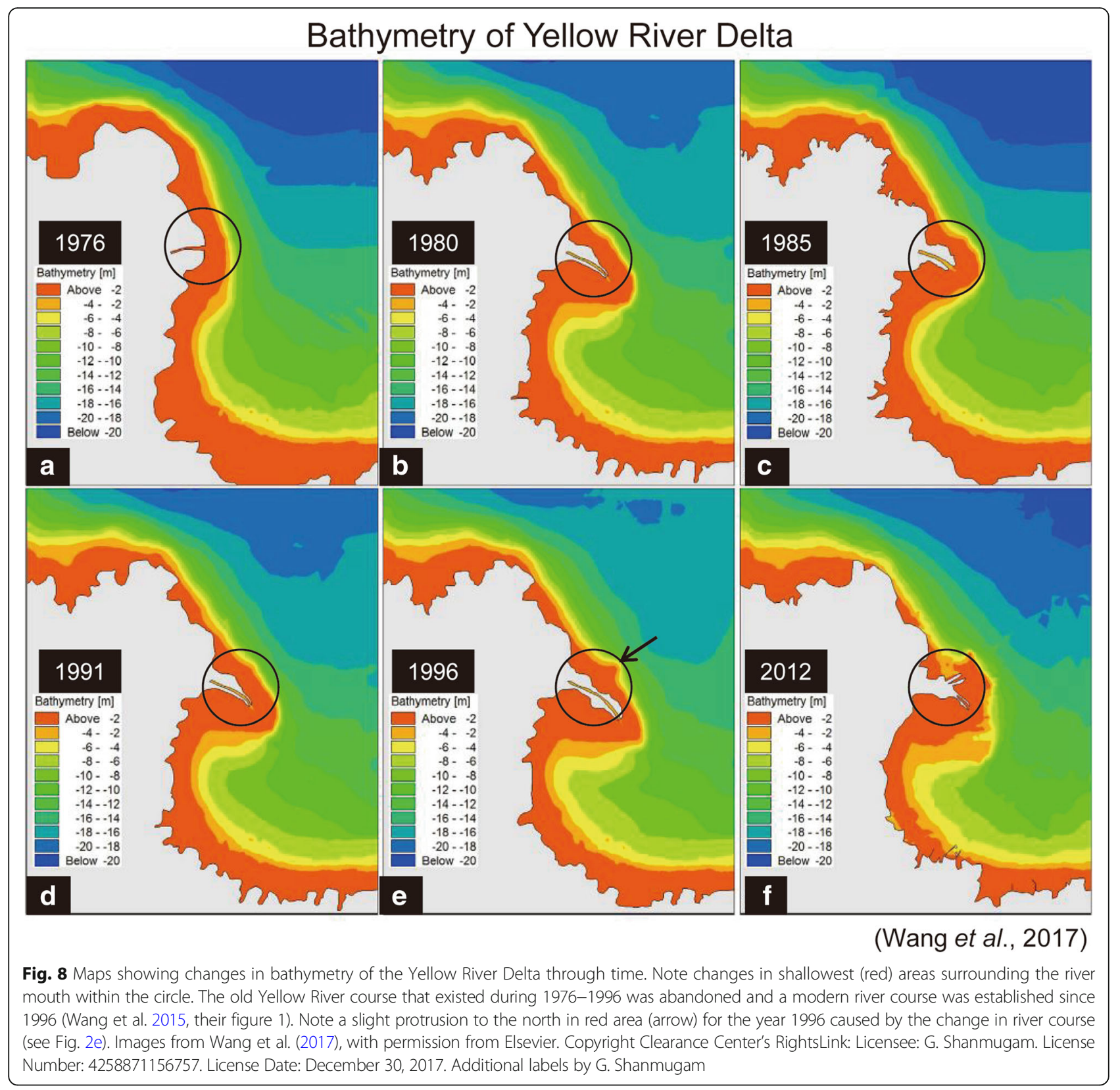

layer without vertical stratification in density or velocity (Fig. 4a), whereas bottom-turbid layers reveal vertical stratification in density and velocity (Fig. 4b). Such a vertical stratification in bottom-turbid layers is similar to the concept of "high-density turbidity current" (Postma et al. 1988, their Fig. 2). The problem here is that stratified high-density turbidity currents are sandy debris flows because of their basal plastic layers induced by high sediment concentration (Shanmugam 1996). In support of a debris flow, Gao et al. (2015, their Fig. 5b) depicted a "detached point" where the flow front is lifted up from the seafloor (Fig. 4b, the red arrow). This phenomenon is identical to the experimental debris flow with a detached and lifted-up front due to hydroplaning (Mohrig et al. 1998, their Fig. 3; see also Shanmugam 2000, his Fig. 15). Although clearly implied, Gao et al. $(2014,2015)$ did not cite the pioneering work of Mohrig et al. (1998) on hydroplaning.

\subsection{Multi-layer hyperpycnal flows}

Morales de Luna et al. (2017) simulated numerically a multi-layer model for hyperpycnal flows on theoretical/ mathematical basis (Fig. 4c). By contrast, Gao et al. 
(2015, their Fig. 5a) considered hyperpycnal flows as a single-layer phenomenon on the empirical basis (Fig. 4a). The problem is that no one has ever documented multi-layer hyperpycnal flows in natural environments. Another problem is that Morales de Luna et al. (2017) have applied the multi-layer model to both hyperpycnal and hypopycnal plumes. Such applications of numerical modeling to both types of density plumes raise the question on the validity of numerical modeling when there are no empirical bases for the existence of multi-layer hyperpycnal flows in nature. This numerical approach is akin to inventing medicine for a hypothetical disease that does not exist.

\subsection{Tide-modulated hyperpycnal flows}

The term "tide-modulated hyperpycnal flow" (Fig. 4d; Wang et al. 2010) is confusing. The reason is that hyperpycnal flows are unidirectional (i.e., travel seaward), whereas tidal currents are bidirectional (i.e., travel both seaward (ebb tide) and landward (flood tide)). In this scenario, it is incongruous to mix tidal currents with hyperpycnal flows in the same nomenclature. In maintaining clarity, any current generated by tides should be called a tidal current.

\subsection{Internal waves}

Wang et al. (2010; see also Wright et al., 1986) suggested internal waves but did not provide empirical evidence for internal waves at the mouth of the Yellow River (Fig. 4d). Internal waves are a complicated oceanographic phenomenon (Shanmugam 2013). For example, internal waves occur only along pycnoclines (Shanmugam 2013), but there is no evidence of pycnoclines at shallow depths where hyperpycnal plumes develop in front of the Yellow River.

In summary, publications on the river-mouth processes of the Yellow River have perpetuated unnecessary conceptual problems by proposing complex processes without empirical basis.

\subsection{Velocity measurements}

In their study on the Yellow River, Wright et al. (1990) reported that strong $\left(\sim 1 \mathrm{~m} \cdot \mathrm{s}^{-1}\right)$ parabathic tidal currents resuspended newly deposited muds and advected them alongshore. It appears that tidal currents are more powerful than hyperpycnal flows. The velocity values used in numerical modeling studies are from tidal currents (e.g., Wang et al. 2010). Disappointingly, there are no empirical data on velocity measurement of hyperpycnal flows from the Yellow River mouth (Wright et al. 1986).

\subsection{Tidal shear front}

Perhaps the most significant contribution on the dynamics of the Yellow River sedimentation is pertaining to the recognition of tidal shear front (Fig. 9a). Li et al. (2001), based upon in-situ measurements and Landsat scanning images, studied spatial-temporal changes in the shear front and associated sedimentation in the subaqueous delta slope of the Yellow River. The results showed that the shear front is an important dynamic factor in controlling rapid accretion at the Yellow River mouth. Suspended sediment converges and is deposited rapidly along the shear front zone. This is because a low-velocity zone is formed between two inverse flow bodies.

Qiao et al. (2008), by combining a three-dimensional tidal front numerical model and a sediment transport module, explained the formation of a tidal shear front that occurs off the Yellow River mouth. Wang et al. (2010) documented the position of the tidal front about $5 \mathrm{~km}$ seaward off the Yellow River mouth (Fig. 9a) and explained the tide-induced density flows on the shelf (Fig. 9b). The importance of these numerical experiments is that the topography with a strong slope off the Yellow River mouth was a determining factor on the generation of a shear front.

The sedimentologic implication of the shear front is that it limits seaward transport of sediments ( $\mathrm{Li}$ et al. 2001; Qiao et al. 2008; Wang et al. 2007, 2010, 2017). If so, the extent of sediment transport into the deep sea by hyperpycnal flows comes into question. In other words, the entire concept of hyperpycnal flows transporting sediment into the deep sea (Mulder et al. 2003; Steel et al. 2016; Warrick et al. 2013; Zavala and Arcuri 2016) is unsupported by the Yellow River, which is considered to be a classic river for hyperpycnal flows.

\subsection{0 $\mathrm{M}_{2}$ tidal dynamics in Bohai and yellow seas}

Wiseman et al. (1986) were one of the early workers who recognized the importance of $\mathrm{M}_{2}$ tidal constituents in the Bohai Sea. Yao et al. (2012) conducted a modeling study of $\mathrm{M}_{2}$ tidal dynamics in understanding the regional tidal mixing and tidal residual currents. There are four regions of low values of $\log _{10}\left(h / U^{3}\right)$ : The inner shelf of Seohan Bay, Kyunggi Bay, the shelf area off the southwest Korean peninsula, and the China shelf area between $34^{\circ} \mathrm{N}$ and $35^{\circ} \mathrm{N}$ (Fig. 10a). All these mixing zones are confined in the Yellow Sea (Fig. 10a). Inside the Bohai Sea, strong residual currents are seen off the Yellow River mouth (Fig. 10b), near Liaodong Bay and north of the Bohai Strait (Fang and Yang 1985). From the above empirical and numerical data, it is clear that the Yellow River mouth is part of a regional tidal setting that comprises both Bohai Sea and Yellow Sea (Fig. 10).

In summary, hyperpycnal flows are not simple processes that begin their journey at plunge points, transporting sediment across the shelf, and end up in the deep sea. They are invariably affected by external controls (see Section 5). For example, the acute impact of 


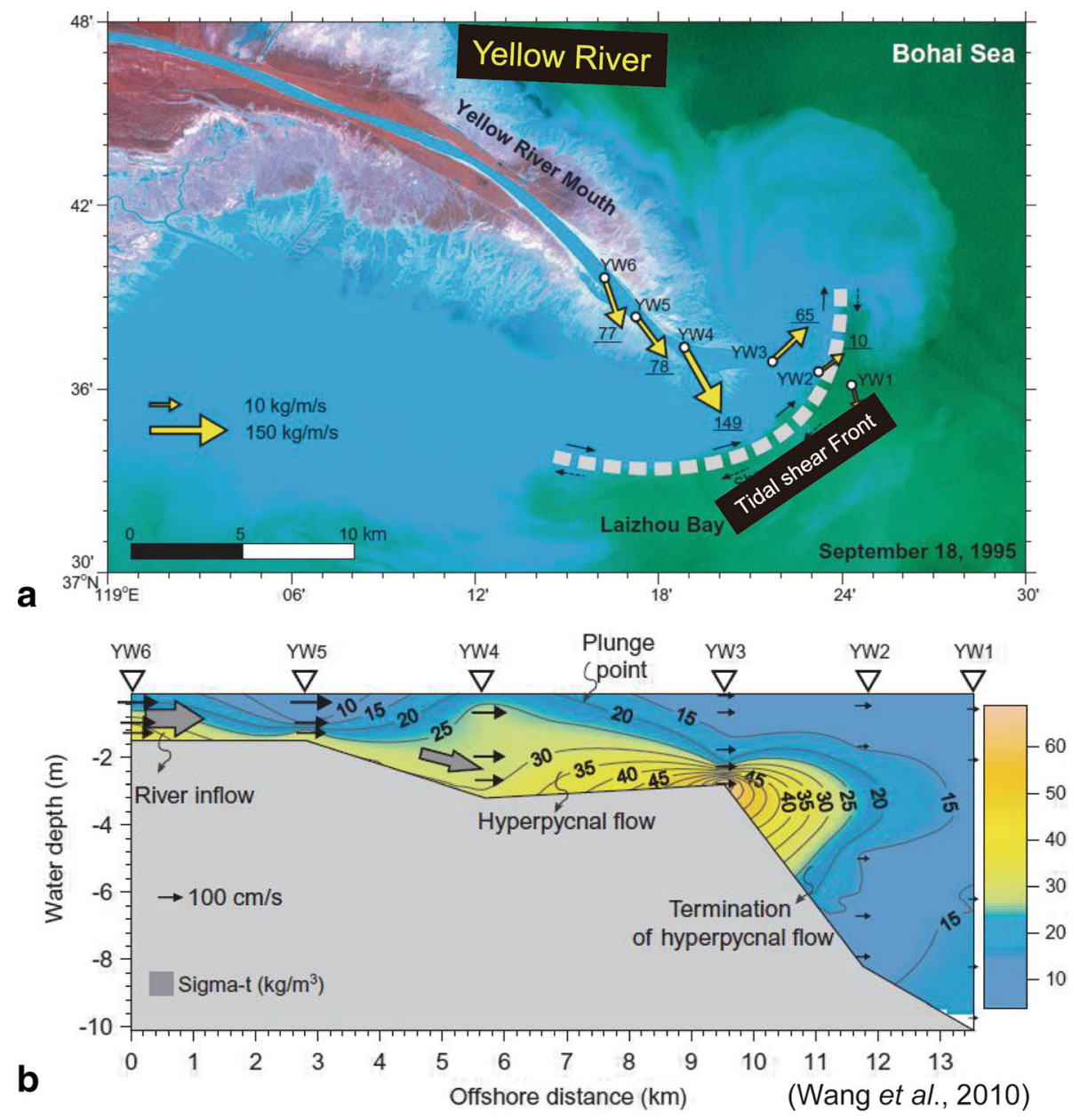

Fig. 9 Tidal shear front. a Satellite image showing the sediment dispersal pattern at the Yellow River mouth and estimated mean depth-integrated sediment flux at six stations in 1995 cruise. Note a tidal shear front (white dashed line); b Distributions of bulk density along a transect through the six stations on 18 September 1995, demonstrating the spatial pattern of a flow extending seaward beneath the ambient sea water. Both from Wang et al. (2010), with permission from John Wiley and Sons. Copyright Clearance Center's RightsLink: Licensee: G. Shanmugam. License Number: 4258840606863. License Date: December 30, 2017. Additional labels by G. Shanmuagam

tidal currents on hyperpycnal flows is well documented in the next case study, which is the Yangtze River.

\section{The Yangtze River, China}

\subsection{Hyperpycnal and hypopycnal plumes}

The Yangtze River is the longest river (about 6,300 km) in Asia. Satellite images show that the Yangtze River generates both hyperpycnal and deflected hypopycnal plumes (Fig. 11a). The Yangtze River mouth is a complex setting in which both ocean currents and tidal currents are affecting sediment dispersal.

\subsection{Ocean currents}

Unlike the Yellow River that enters a protected Bohai Bay from major ocean currents, the Yangtze River enters the East China Sea affected by the warm, north-flowing Kuroshio Current (Fig. 11b). As a consequence, muddy sediments brought by the Yangtze River are redistributed and deposited as a mud belt on the inner shelf (Wu et al. 2016). This mud belt is evident on the satellite images (Fig. 11a). This mud belt is distinctly different from the fan-shaped or lobate deposits of hyperpycnal flows associated with the Yellow River (Fig. 2e). Liu et al. (2006) proposed a sediment dispersal model by ocean currents for sediments supplied into the East China Sea by the Yangtze River (Fig. 11c). Ocean currents are a global phenomenon (Talley 2013) with implications for sediment distribution in the world's oceans (Shanmugam 2017b).

\subsection{Tidal river dynamics}

Similar to the Yellow River, both terms "delta" and "estuarine" are used for the Yangtze River mouth (e.g., Liu et al. 1992). However, evidence for a tide-dominated estuary is compelling. 


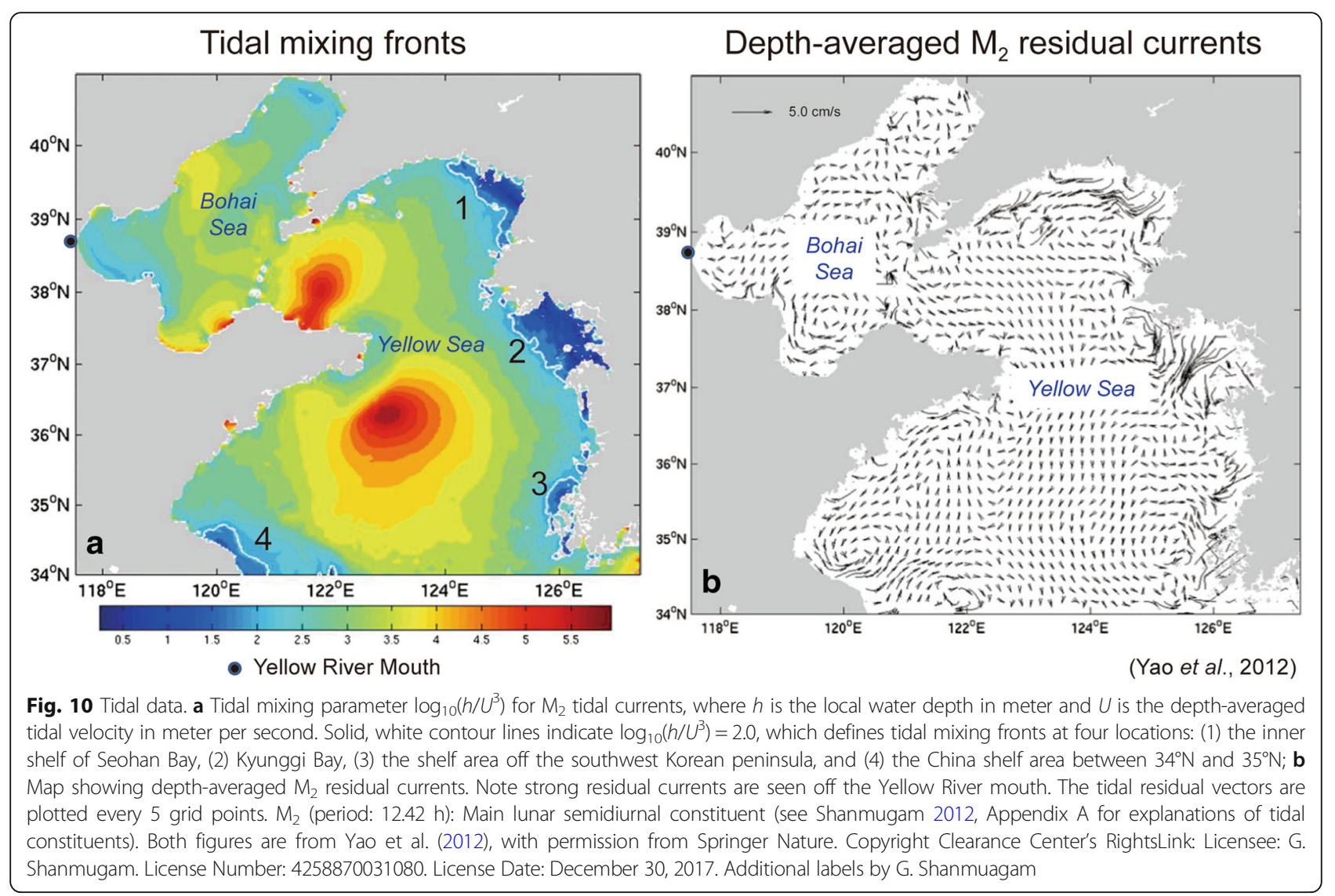

Hoitink and Jay (2016) reviewed tidal river dynamics of the world's rivers and classified the Yangtze as a "tidal river".

Guo et al. (2015) documented that the tidal influence (salt-wedge intrusion) can extend to Datong, which is $650 \mathrm{~km}$ upstream from the river mouth (Fig. 12a).

Guo et al. (2014) documented river-mouth bars (Fig. 12b) that are analogous to tidal sand bars (Dalrymple et al. 1990). Liu et al. (1992) reported the development of estuarine sand bars. In support of this observation, a 1997 bathymetric map reveals river-mouth bars, mimicking tidal sand bars typical of tide-dominated estuaries (see Dalrymple et al. 1990; Shanmugam et al. 2000).

Guo et al. (2015) documented the changes in mean water level at Datong with respect to discharge associated with tides (Fig. 12c).

Tides in the Yangtze River Estuary are semidiurnal with the average tidal range of $2.76 \mathrm{~m}$ and the maximum of $4.62 \mathrm{~m}$ (Lu et al. 2015) or $5.0 \mathrm{~m}$ (Chen et al. 1998).

Tidal flow velocity at the river mouth was measured to be $1 \mathrm{~m} \cdot \mathrm{s}^{-1}$ (Milliman et al. 1985).

Hori et al. (2002) proposed a tide-dominated delta with sand-mud couplets and bi-directional cross laminations for the Yangtze Holocene succession.

The differences between a common river and a tidal river affect sedimentation at plunge points (Fig. 12d).
For example, unlike river-dominated deltas with unidirectional sediment transport (i.e., seaward), tide-dominated estuarine systems are prone to bidirectional transport of sediment (i.e., both seaward and landward) (Dalrymple 1992; Dalrymple et al. 1992). Under such conditions, the idea of sediment transport by hyperpycnal flows from the river mouth to the deep sea, traveling across the shelf, is misleading.

Although both the Yellow and the Yangtze Rivers develop hyperpycnal lows at their river mouths, transport of hyperpycnal sediments from the river mouth to the deep sea has been blocked or diverted by different external controls, such as tidal shear front and ocean currents (Fig. 13). This important oceanographic control has been overlooked in studies of hyperpycnites (e.g., Zavala and Arcuri 2016). In this review, 15 external controls have been identified from global case studies (see Section 5).

\section{External controls}

External controls are allogenic in nature, which are external to the depositional system, such as uplift, subsidence, climate, eustacy, etc. However, external controls of density plumes are much more variable and include some common depositional processes (e.g., tidal 


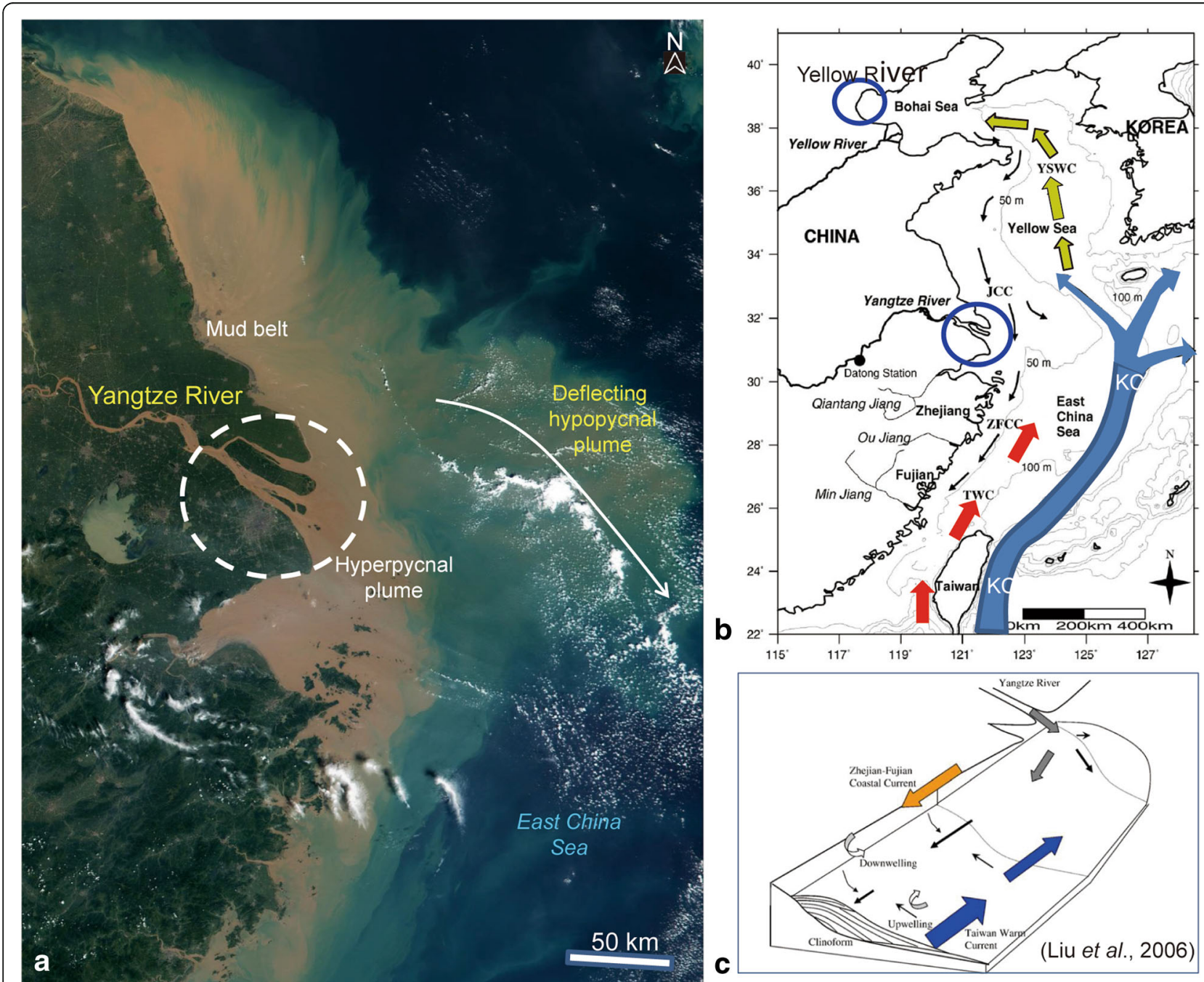

Fig. 11 Data from the Yangtze River. a Satellite image showing the Yangtze River plunging into the East China Sea. Note development of both hyperpycnal plume (yellow color due to high sediment concentration) near the river mouth and hypopycnal plume (blue color due to low sediment concentration) on the seaward side. Note deflected hypopycnal flows that move southward (white arrow), possibly due to modulation by south-flowing shelf currents. In a recent study, Luo et al. (2017) recognized that extended and deflected density plumes (white arrow) tend to develop during winter months, which are absent during the summer months. Note sheet-like mud belt developed along the inner shelf due to contour-following shelf currents. White dashed circle=River mouth. See Fig. 12a for the river course; see also Fig. 7a. River image credit: NASA Visible Earth, Jacques Descloitres, MODIS Land Science Team. https://visibleearth.nasa.gov/view.php?id=55219. Image acquired on September 16, 2000. Instrument: Terra-MODIS; b Map showing warm Kuroshio Current (KC) in the East China Sea and Yellow Sea. TWC = Taiwan Warm Current; YSWC = Yellow Sea Warm Current; ZFCC = Zhejiang-Fujian Coastal Current; JCC = Jiangsu Coastal Current. Blue circles: Yangtze and Yellow River mouths. From Liu et al. (2006) with additional labels by G. Shanmugam; c Conceptual model of sedimentary and oceanographic processes affecting the sediment dispersal at both subaqueous delta and alongshore deposits associated with the Yangtze River. From Liu et al. (2006) with additional labels by G. Shanmuagm. Both B and C figures with permission from Elsevier. Copyright Clearance Center's RightsLink: Licensee: G. Shanmugam. License Number: 4258820168883. License Date: December 30, 2017

currents). At least, 15 external controls of plumes have been recognized in this review (Table 1):

1) Tidal shear front (Fig. 9): The Yellow River (Wang et al. 2010).

2) Ocean currents (Fig. 11): The Yangtze River (Liu et al. 2006).

3) Tidal currents (Table 1): San Francisco Bay (Barnard et al. 2006; NASA 2017).
4) Monsoonal currents (Jagadeesan et al. 2013).

5) Wave action (Hawati et al. 2017).

6) Cyclones (Table 1): Gulf of Mexico; U.S. Atlantic shelf (Shanmugam 2008a, 2008b).

7) Tsunamis (Table 1): Sri Lanka, Arabian Sea (Shanmugam 2006b).

8) Braid delta and related high gradients and coarse sediments (Fig. 6): Alaska, Pacific Ocean (McPherson et al. 1987). 


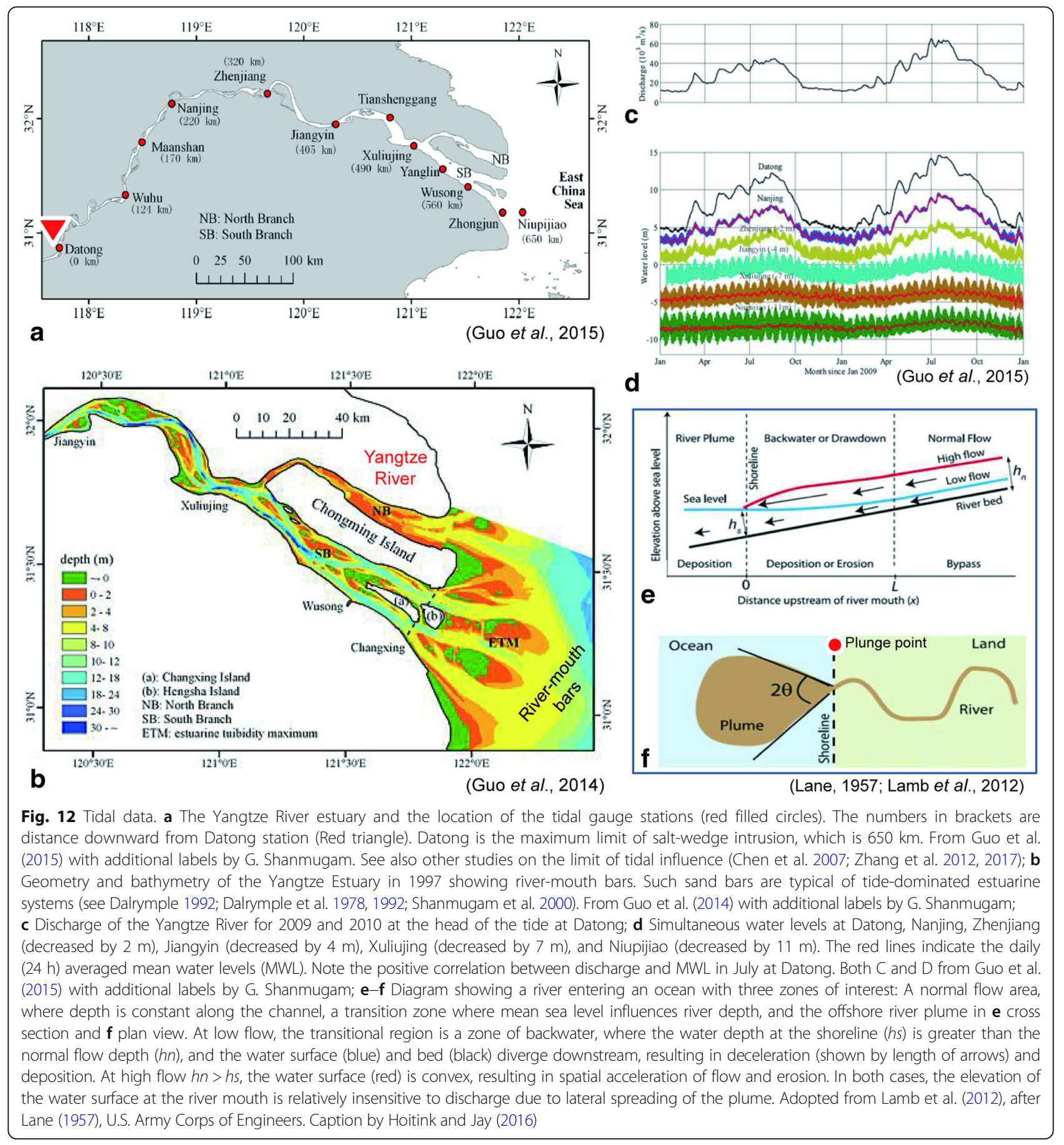

9) Seiche in lakes (Table 1): Lake Erie (NASA 2017). Seiche is a large standing wave that occurs when strong winds and a quick change in atmospheric pressure push water from one end of a body of water to the other. de Jong and Battjes (2004) discussed the atmospheric origin of seiche.

10) Upwelling (Table 1): Off Namibia (Shillington et al. 1992).
11) Fish activity (Table 1): The Great Bahama Bank (Broecker et al. 2000).

12) Volcanic eruptions (Table 1): Bering Sea (NASA 2017).

13) Coral reef (Table 1): South Pacific Ocean (NASA 2017).

14) Pockmarks: Carolina Continental Rise, North Atlantic Ocean (Paull et al. 1995).

15) Internal waves and tides (Masunaga et al. 2015). 

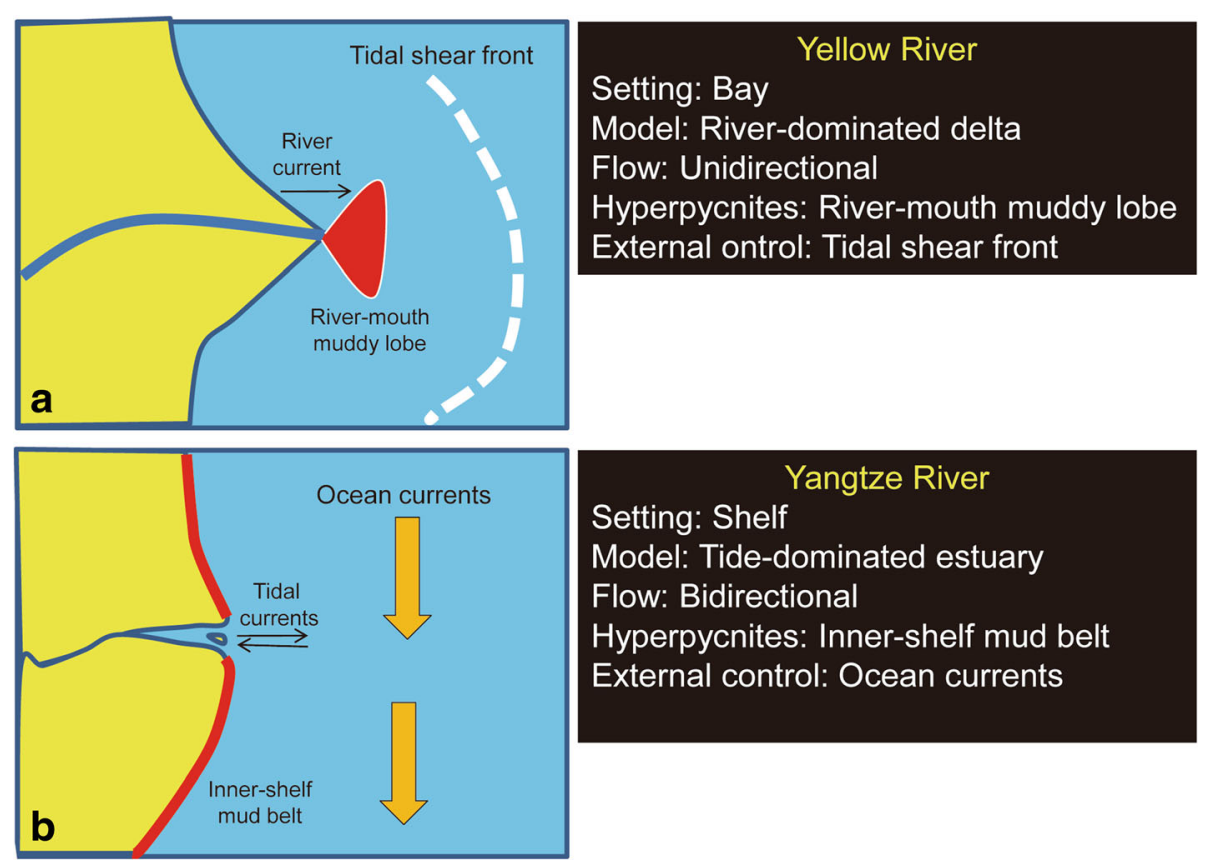

Fig. 13 Comparison of conceptual diagrams showing differences in depositional models between a the Yellow River and $\mathbf{b}$ the Yangtze River. Note external controls on the distribution of muddy hyperpycnites. In the Yellow River, a tidal shear front prevents seaward transport of sediment. In the Yangtze River, ocean currents deflect plumes and deposit them as inner-shelf mud belt

I have discussed the importance of external controls, such as tidal shear front and ocean currents earlier. Future studies should consider external controls in developing meaningful depositional models.

\section{Recognition of ancient hyperpycnites}

Recognition of ancient hyperpycnites is rare. However, there are studies that claim that hyperpycnites can be recognized using various criteria. In the following discussion, problems associated with recognizing ancient hyperpycnites are identified.

\subsection{The hyperpycnite facies model}

Mulder et al. (2003) proposed a facies model for hyperpycnites (Fig. 14a). This model is based on a hypothesis that hyperpicnite facies is a function of the magnitude of the flood at the river mouth. According to this hypothesis, hyperpycnites accurately record the rising and falling discharge of a flooding river in terms of sediment-size, inverse grading to normal grading in ascending order (Fig. 14a), primary sedimentary structures, bed thickness, and erosional contacts. Mulder et al. (2003) were the first authors to propose a facies model with an internal erosional surface (Fig. 14a).

In testing Mulder et al. (2003) hypothesis, Lamb et al. (2010) conducted laboratory flume experiments and concluded that the hypothesis is unsupported by experimental results. Furthermore, Clare et al. (2016) reported that the largest river discharges did not create hyperpycnal flows based on field monitoring of the Squamish Delta, British Columbia, Canada during 2011, thus disputing the hypothesis.

Although ichnological signatures (i.e., bioturbation and trace fossils) are claimed to be characteristic features of hyperpycnites (Buatois et al. 2011) and contourites (Stow and Faugères, 2008), skepticism about these claims exists (Shanmugam, 2002, 2018d).

\subsection{Inverse to normal grading}

Following the concept of Mulder et al. (2003), Wilson and Schieber (2017) and Yang et al. (2017a) recognized ancient hyperpycnites based on inverse to normal grading. However, the origin of inverse grading by waxing flows is an unresolved issue (Shanmugam 2002). For example, mechanisms which are commonly used to explain inverse grading are (1) dispersive pressure, caused by grain-to-grain collision which tends to force larger particles toward the zone of least rate of shear (Bagnold 1954), (2) kinetic sieving, by which smaller particles tend to fall into the gaps between larger particles (Middleton 1967), and (3) the lift of individual grains towards the top of flow with lower pressures (Fisher and Mattinson 1968). Nevertheless, Mulder et al. (2001) did not consider any of these alternative mechanisms.

Yang et al. (2017a) recognized normal grading in the Triassic Yanchang Formation in the Ordos Basin, Central China, and interpreted normal grading as 


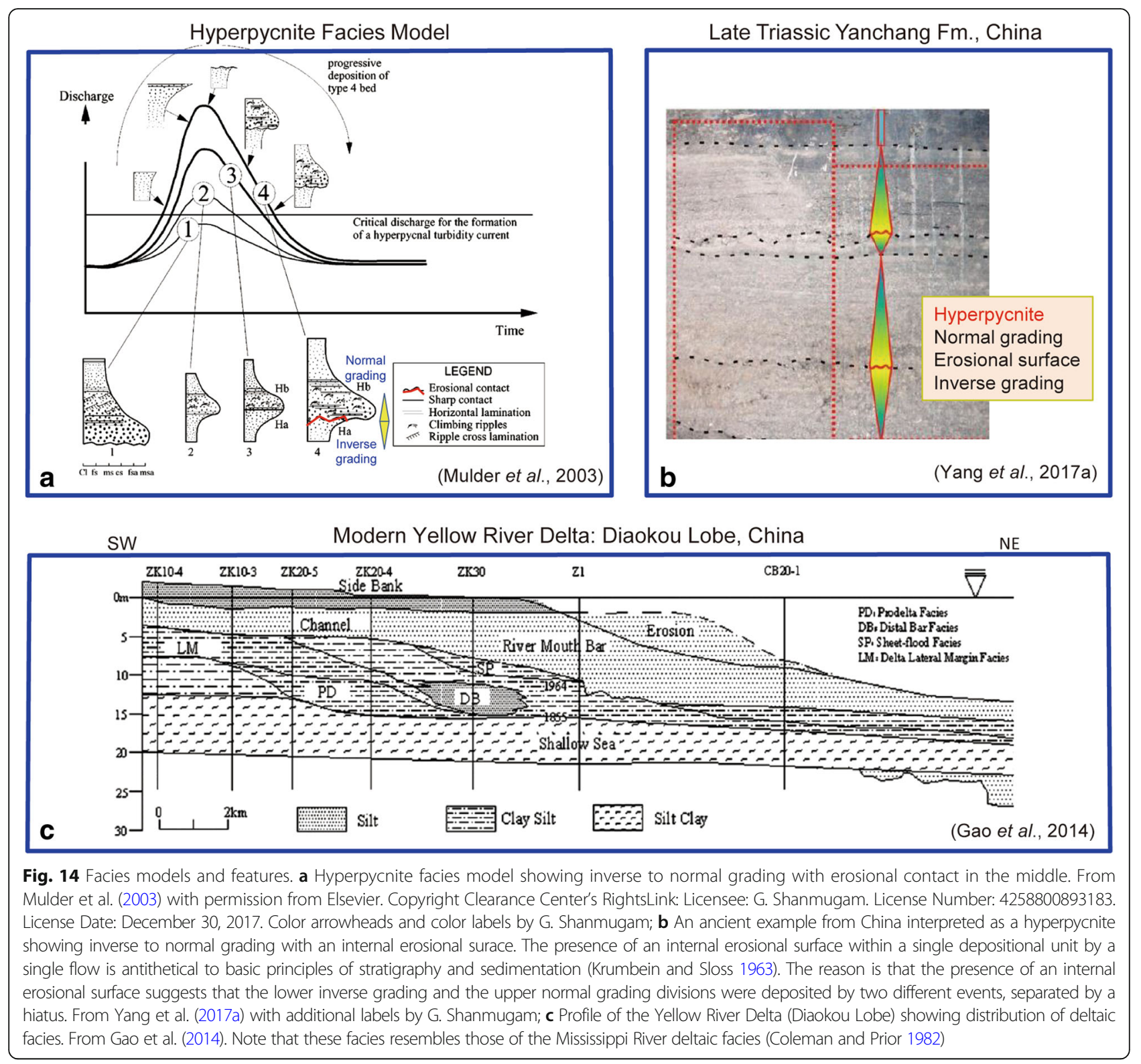

hyperpycnite (Fig. 14b). However, normal grading in the Yanchang Formation was previously interpreted as turbidites (Zou et al. 2012).

Wilson and Schieber $(2014,2017)$ described a muddy unit with normal to inverse grading in ascending order from the Devonian Lower Genesee Group, Central New York, which they interpreted as hyperpycnites. These muddy units were previously interpreted as turbidites by other researchers. Muddy turbidity currents and hyperpycnal flows are one and the same, according to some authors (see Kostic and Parker 2003; Lamb et al. 2010). As explained earlier, it is wrong to equate hyperpycnal flows with turbidity currents on fluid dynamical principles (see Section 2).

\subsection{Internal erosional surface}

Following Mulder et al. (2003), Yang et al. (2017a) claimed that internal erosional surfaces, which occur between basal inversely graded layer and upper normally graded layer, are the diagnostic criteria of hyperpycnites (Fig. 14b). Conventionally, a genetic facies model is designed for a single depositional event, without internal hiatuses. A classic example is the turbidite facies model or the "Bouma Sequence" (Bouma 1962). In fact, Walther's Law (Middleton 1973) is not meaningful for sequences with internal hiatuses. This is because a hiatus can represent a considerable span of time (spanning millions of years) that is missing along an erosional surface (Howe et al. 2001). Therefore, it is sedimentologically meaningless to relate 
layers above and below an erosional surface, with a break in deposition in the middle, to the same process (Fig. 14b). Yang et al. (2017a) are not the only group of authors who promote this flawed concept (there are others, e.g., Wilson and Schieber 2017).

Importantly, no one has reproduced the entire inverseto normally-graded sequence with internal erosional surface (i.e., the hyperpycnite facies model) in laboratory flume experiments; nor has anyone documented this sequence from modern settings. The conceptual hyperpycnite model exists only in theory in publications, not in the real-world sedimentary record.

\subsection{Traction structures}

Wilson and Schieber $(2014,2017)$ interpreted traction structures in mudstone as hyperpycnites. Traction structures are characteristic attributes of bottom currents reworking by contour currents, tidal currents, wind-driven currents, and baroclinic currents (Hollister 1967; MartínChivelet et al. 2008; Shanmugam 2008b, 2013, 2016b, 2017b; Shanmugam et al. 1993). Mutti (2009) attributed the origin of hummocky cross-stratification (HCS), normally associated with storm deposits, to deposition by hyperpycnal flows. Gao et al. (2014) studied the modern Yellow River Delta and proposed a facies distribution (Fig. 14c). The Yellow River Delta model exhibits many attributes of the classic Mississippi River Delta (Coleman and Prior 1982), including traction currents. In summary, there is a wide range of opinions in interpreting traction structures.

Distinguishing hyperpycnites from bottom-current deposits that are ubiquitous in the world's oceans is a challenge. In particular, contourites are of importance (Hollister 1967; Rebesco and Camerlenghi 2008). The generation of thermohaline-induced density flows is similar to that of hyperpycnal flows. For example, the deep-water masses in the world's oceans are caused by differences in temperature and salinity. When sea ice forms in the polar regions due to freezing of shelf waters, sea water experiences a concurrent increase in salinity due to salt rejection and a decrease in temperature. The increase in the density of cold saline (i.e., thermohaline) water directly beneath the ice triggers the sinking of the water mass down the continental slope and the spreading of the water masses to other parts of the ocean. These are called thermohaline water masses and are akin to hyperpycnal flows due to their excess density. It is worth noting that facies models of both contourites (Stow and Faugères 2008) and hyperpycnites (Fig. 14a) exhibit inverse to normal grading in ascending order and both have internal hiatus (Shanmugam 2016b, his Fig. 9.19).

\subsection{Massive sandstones}

Massive sandstones, considered to be a recognition criteria for hyperpycnites (Steel et al. 2016; Zavala and
Arcuri 2016), are not unique to deposits of hyperpycnal flows. There are alternative processes that can equally explain the origin of massive sands. Flume experiments, carried out at the St. Anthony Falls Laboratory of the University of Minnesota in Minneapolis during 19961998, demonstrated that massive sands can be deposited by a sudden freezing of sandy debris flows (Shanmugam 2000, his Fig. 18a; Marr et al. 2001, their Fig. 7). In discussing hyperpycnites, Steel et al. (2016, p. 1720) stated that "Although scattered shelf-derived shell fragments suggest an initially turbulent hyperpycnal flow, abrupt lobe terminations, lack of tractional structures, and convolute bedding from rapid dewatering indicate en masse deposition". En masse deposition is typical of debris flows (Dott 1963; Enos 1977; Hampton 1972; Johnson 1970; Middleton and Southard 1977; Shanmugam and Benedict 1978; Takahashi 1981). In their global study, Stow and Johansson (2000) attributed the origin of massive sands to sandy debris flows and high-density turbidity currents.

In their experimental study, Breien et al. (2010) demonstrated that massive sands can be deposited by laminar sediment flows. The massive sands in their experiments represent deposition from a "fluidized segment" of the flow. Breien et al. (2010, p. 977) considered fluidization as "...a mechanism where the mass moves like a fluid, and as the particles settle due to gravity, the pore fluid is displaced upwards, thus providing further grain support". Steel et al. (2016) indeed reported that there is evidence for dewatering in the cores; so fluidization is a viable explanation for at least some of the cored intervals studied by Steel et al. (2016).

Conventionally, massive sand intervals are interpreted as the Bouma Ta division of a turbidite bed (Middleton and Hampton 1973). The Ta division has also been attributed to deposition from sandy debris flows (Shanmugam 1997). In summary, interpreting massive sands is one of the most controversial topics in sedimentology.

\subsection{Lofting rhythmites}

Zavala and Arcuri (2016, their Fig. 18), in justifying their criteria for recognizing hyperpycnites, presented a core photograph showing rhymites, which they called "lofting rhythmites". The core photograph is from the modern Orinoco Fan, off Orinoco Delta in Eastern Venezuela (their Fig. 15). Such rhythmites are common in deep-water tidal deposits (Cowan et al. 1998; Shanmugam 2003). The Orinoco Delta is a classic tide-dominated delta (Chen et al. 2014). Tidal range at coast in the Orinoco Delta area is $2.6 \mathrm{~m}$ (Warne et al. 2002). Tidal rhythmites have been documented from the Orinoco Delta (Chen et al. 2017). It is common for tidal rhythmites to occur both at shallow-water and at deep-water environments in a tidal setting, such as the 
Oriente Basin, Ecuador (Shanmugam et al. 2000) and the Krishna-Godavari Basin, Bay of Bengal (Shanmugam et al. 2009). This is because tidal currents operate in both shallow-water and deep-water environments concurrently (Boyd et al. 2008; Shanmugam et al. 2009; Shepard et al. 1979). Importantly, tidal rhythmites can be explained by empirical data on daily tidal cycles (Visser 1980). Zavala and Arcuri (2016) did not consider alternative tidal origins for the Orinoco fan deposits with rhythmites.

\subsection{Plant remains}

Plant remains have been used as a criterion for recognizing hyperpycnites (Zavala and Arcuri 2016). The problem is that shelf currents operate on many continental margins. For example, Imran and Syvitski (2000) studied the Northern California Margin near the mouth of the Eel River and suggested that hyperpycnal flows may be influenced by the along-shelf currents and be deflected northward away from the canyon. Under such conditions, shelf currents can carry the plant remains away from the river mouth, and supply them to a site of initiation of "classic" turbidity currents near canyon heads. Such shelf-current transported plant remains would result in erroneous recognition of hyperpycnites in the deep sea. Saller et al. (2006) interpreted leaves in deep-water turbidites. Also, tidal currents are important in transporting plant remains. Abundant coaly carbonaceous fragments have been reported in deep-marine lithofacies with double mud layers, typical of tidal

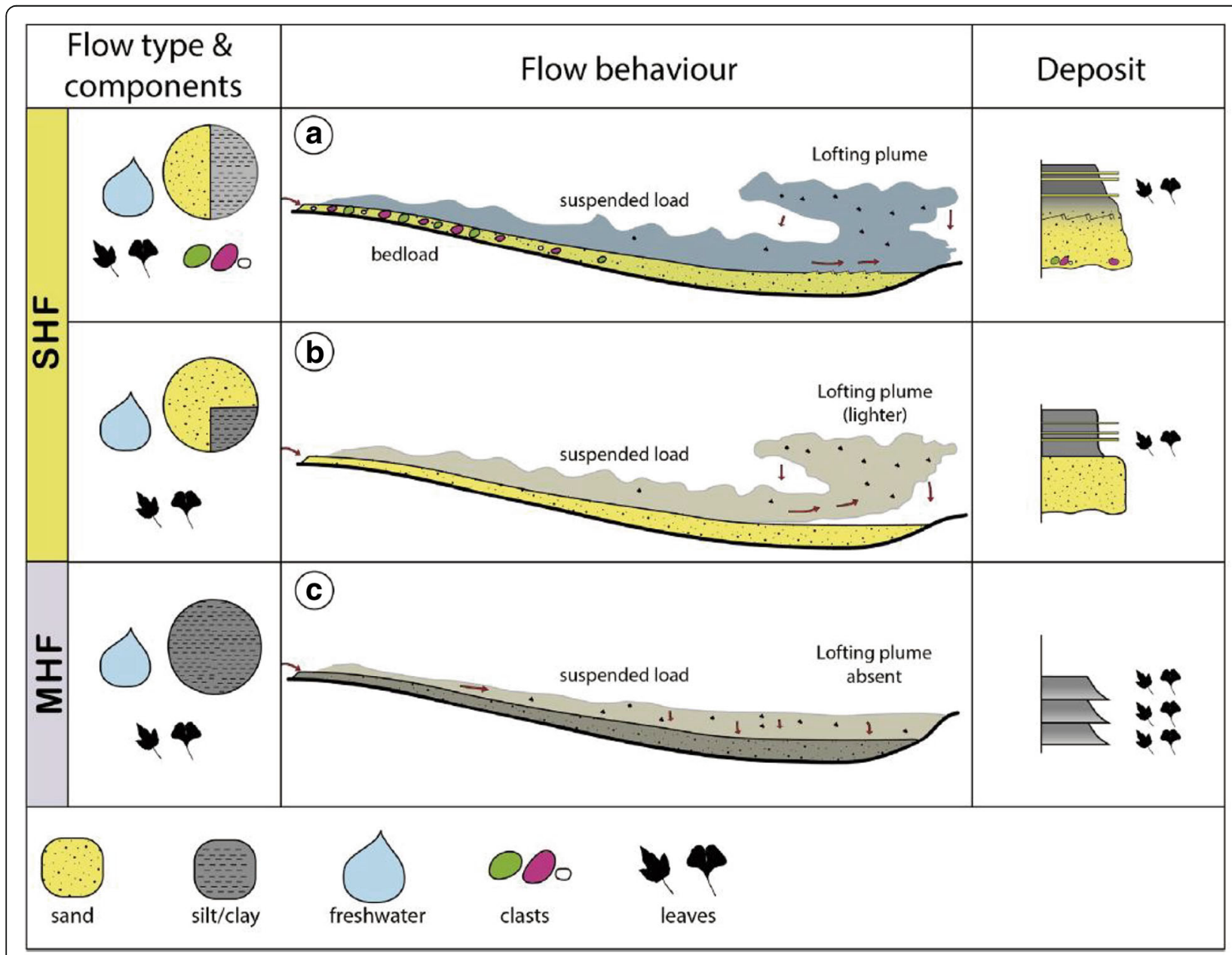

SHF: Sandy hyperpycnal flows

(Zavala and Arcuri, 2016) MHF: Muddy hyperpycnal lows

Fig. 15 Hypothetical sandy and muddy hyperpycnal flows and their related deposits. The theoretical concept of sandy hyperpycnal flows transporting sand and gravel across the shelf has never been documented in modern shelf environments. From Zavala and Arcuri (2016), with permission from Elsevier. Copyright Clearance Center's RightsLink: Licensee: G. Shanmugam. License Number: 4258810111938. License Date: December $30,2017$. Additional labels by G. Shanmugam 
rhythmites (Visser 1980), from a Pliocene submarine canyon in the Krishna-Godavari Basin, Bay of Bengal (Shanmugam et al. 2009).

In addition to shelf currents and tidal currents, wind is a common factor that influences sediment transport in coastal areas. The movement of sediment has been basically triggered by breaking waves. This factor coupled with the geographic location of certain countries like Indonesia where not only plant remains are abundant but also the region is affected by extreme monsoonal winds. For example, at Coastal Region of Timbulsloko Demak in Indonesia, maximum speed of wind can reach at 23 knots $\left(11.83 \mathrm{~m} \cdot \mathrm{s}^{-1}\right)$ from December to February, wind direction predominantly from North-West direction. Correlation between breaking waves and sediment transport is linear (Hawati et al. 2017). McGowen et al. (1977) documented the role of longshore currents in the Gulf Shoreline of Texas in transporting sediment of all sizes.

I already discussed the effects of warm ocean currents in redistributing hyperpycnites along the inner shelf of the East China Sea (Fig. 11b). In light of these oceanographic factors, plant remains are not a viable criterion for recognizing hyperpycnites.

\section{Submarine fans}

Bouma et al. (1985) documented characteristics of both modern and ancient submarine fans. Various aspects of submarine fans were also discussed by other authors (Mutti 1992; Shanmugam and Moiola 1988; Shanmugam 2016a). Conventionally, submarine fans were related to deposition from turbidity currents (Mutti 1992). Recently, origin of submarine fans have been attributed to hyperpycnal flows (Warrick et al. 2013; Zavala and Arcuri 2016).

\subsection{Classification}

Zavala and Arcuri (2016) proposed two types of hypothetical hyperpycnal flows, namely, sandy and muddy types (Fig. 15). In this classification, the lofting plume (i.e., positively buoyant) in sandy hyperpycnal flows is of significance. Similar lofting models were also proposed by Steel et al. (2016).

It is worth noting that the wake part of a turbidity current discussed by Allen (1985) is somewhat analogous to the lofting part. Zavala and Arcuri (2016) also used the classification of turbidity currents by Mutti et al. (1994) into low-density turbidity currents and high-density turbidity currents. Despite our poor

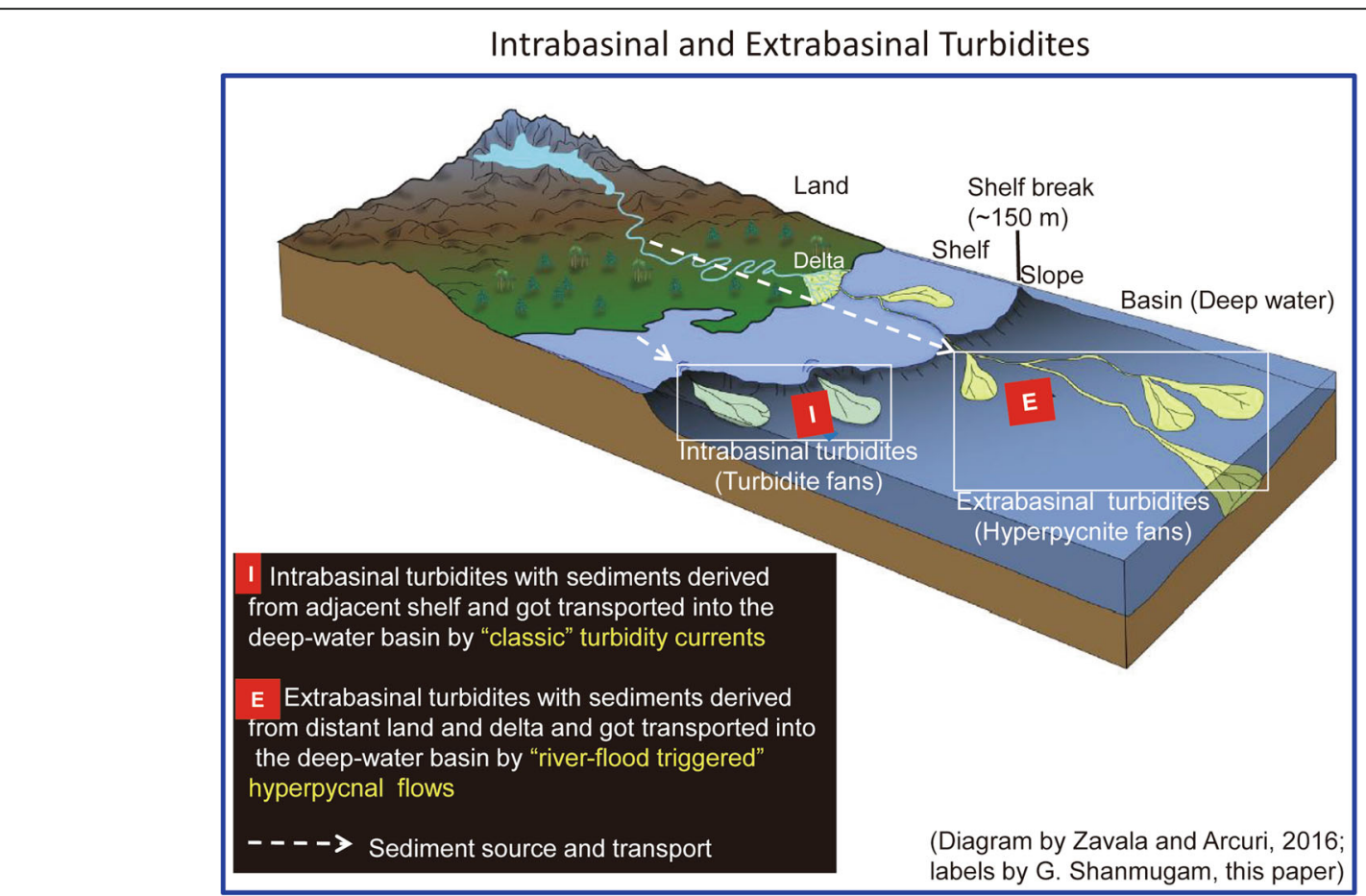

Fig. 16 Facies conceptual block diagram showing the occurrence of intrabasinal (I) and extrabasinal (E) turbidites. Note that extrabasinal turbidites receive a direct supply from rivers in flood, and can accumulate shelfal or deep marine deposits. This model ignores external controls, such as tidal shear fronts (see Fig. 9) and ocean currents (see Fig. 11), which prevent transport of hyperpycnal sediments from the river mouth to the deep sea. This model also ignores types of submarine canyons (Figs. 17 and 18), which are critical for fan deposition (see the text). Block diagram from Zavala and Arcuri (2016), with permission from Elsevier. Copyright Clearance Center's RightsLink: Licensee: G. Shanmugam. License Number: 4258810111938. License Date: December 30, 2017. Additional labels by G. Shanmugam 
understanding of the behavior of high-density turbidity currents and hyperpycnal flows in deep-water environments (Shanmugam 2016a), Zavala and Arcuri (2016) proposed two types of hyperpycnal flows, namely, sandy and muddy types. Importantly, they proposed two types of turbidites, namely "intrabasinal turbidites" and "extrabasinal turbidites" (Fig. 16). Intrabasinal turbidites are those with sediments derived locally from adjacent shelf and got transported into the basin by "classic" turbidity currents. In contrast, extrabasinal turbidites are those with sediments derived from distant land and delta and got transported into the basin by "flood-triggered" turbidity currents or hyperpycnal flows (Fig. 16). In other words, large river-delta fed submarine fans on passive continental margins, such as the Mississippi Fan and the Amazon Fan, would be classified as extrabasinal turbidite. Because that deposits of hyperpycnal flows are called "hyperpycnites" (Mulder et al. 2002), large submarine fans could be termed hyperpycnite fans. These conceptual fan models have inherent problems.

\subsection{Problems}

1) The concept of lofting hyperpycnal flow is problematic (Fig. 15) because it defies basic priciples of buoyancy. In discussing buoyancy effects in fluids, Turner (1980) explained that positively buoyant plumes cannot be hyperpycnal (i.e., plume with excess density cannot loft). By definition, hyperpycnal flows are negatively buoyant due to their excess density.

2) Zavala and Arcuri's (2016) classified turbidity currents and fans based on provenance (internal source versus external source), which is in conflict with the conventional definition of turbidity currents based on Newtonian rheology and turbulent state (Dott 1963; Sanders 1965).

3) The hypothetical model of extrabasinal turbidites and related hyperpycnite fans is untenable for two reasons. First, the concept of high-density turbidity currents, which serves as the basis, is not only theoretically flawed (Shanmugam 1996), but also

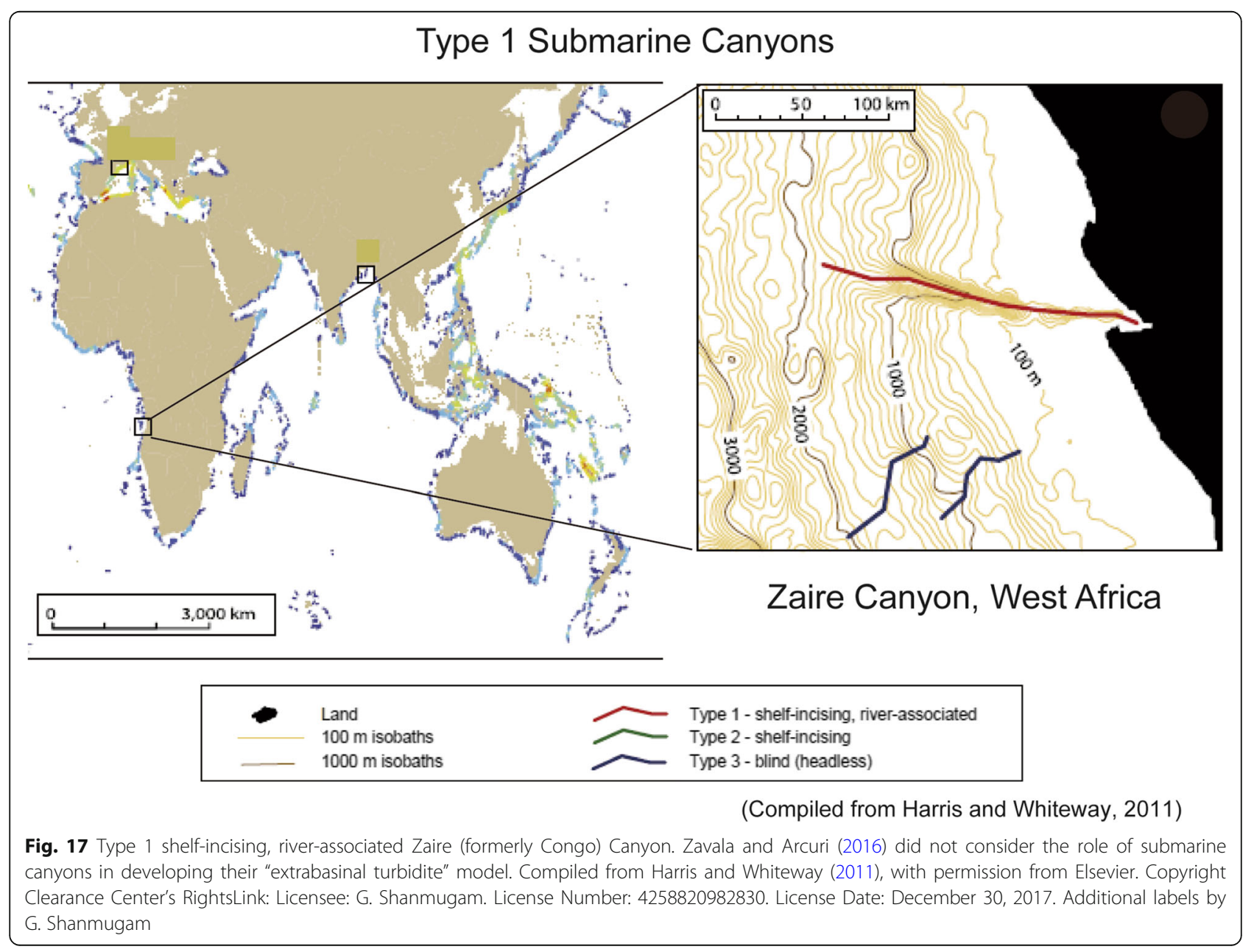


empirically undocumented in the world's oceans (Shanmugam 2017a). Second, the model fails to take into account the most fundamental factor on developing submarine fans, which is a submarine canyon (see Section 8).

\subsection{Grain size}

Modern and ancient submarine fans contain a complex blend of gravel, sand, and mud (Shanmugam and Moiola 1988). However, hyperpycnal flows cannot be responsible for transporting gravel and sand from the land, carrying them $10-100 \mathrm{~km} \cdot \mathrm{s}^{-1}$ across the shelf (Fig. 3), and delivering them to the deep sea. For example, no one has ever documented by direct measurements or observations of transport of gravel and sand by hyperpycnal flows in suspension from the shoreline to the deep sea in modern settings. Without acknowledging this fundamental lack of empirical data, Warrick et al. (2013) suggested formation of submarine fans by hyperpycnal plume-derived sediments in the Santa Barbara Channel, California. Shallow-water muddy hyperpycnal flows should not be confused with deep-water sandy turbidity currents (Shanmugam 2012).
In a comprehensive review of hyperpycnal flows, Talling (2014, p. 179) concluded that "Weak and dilute flows generated by plunging hyperpycnal flood discharges most likely deposits thin $(\mathrm{mm}$ to $<10 \mathrm{~cm})$ and fine grained sediment layers, similar to those documented for hyperpycnal flows in lakes and reservoirs (his Fig. 8d, e). The available field observations suggest that they do not form meter-thick sand layers in deep water settings, as has been previously proposed (Mulder et al. 2003)".

\subsection{Modern analogs}

Steel et al. (2016) claimed that "... hyperpycnal flows became positively buoyant and lifted off the seabed, resulting in well-sorted, structureless, elongate sand lobes". However, such positively buoyant hyperpycnal plumes have never been documented in modern shelf environments. Steel et al. (2016, p. 1717) also claimed that "Turbidity currents generated by plunging of sediment-laden rivers at the fluvial-marine interface, known as hyperpycnal flows, allow for cross-shelf transport of suspended sand beyond the coastline". Because their Fig. 2 B1 shows medium-grained sand, the authors imply that

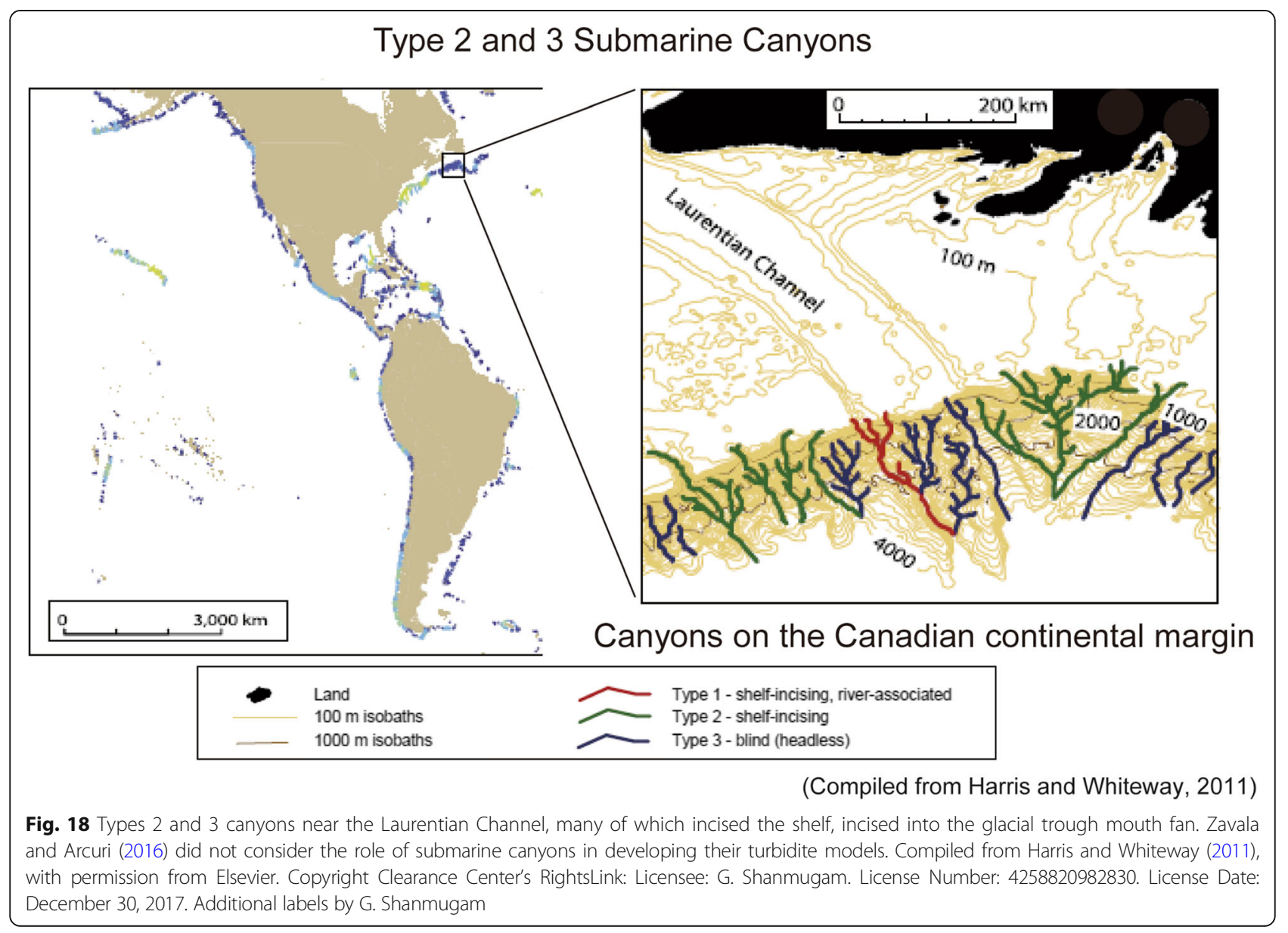


medium-grained sands in the Santa Barbara Channel were transported by lofted hyperpycnal flows (or lofted turbidity currents). But there are no literatures on modern analogs where researchers have documented by direct observations of medium-grained sands being lofted by hyperpycnal flows and those sands being transported across the shelf. Specific publications on modern analogs of lofted hyperpycnal flows with empirical data on their physical properties (e.g., flow velocity, fluid density, grain size, sediment concentration, etc.) are nil.
Experimental studies by Kostic et al. (2002) and Lamb et al. (2010) showed that muddy "turbidity currents" or "hyperpycnal flows" are generated at plunge points. Gladstone and Pritchard (2010), who demonstrated lofting of turbidity currents in laboratory experiments, used the fine fraction with an average grain diameter of $12.8 \mu \mathrm{m}$ and the coarse fraction of $36.5 \mu \mathrm{m}$. In other words, all these experiments revealed that hyperpycnal flows are strictly muddy flows and they do not carry medium- to coarse-sand or gravel in suspension. Other

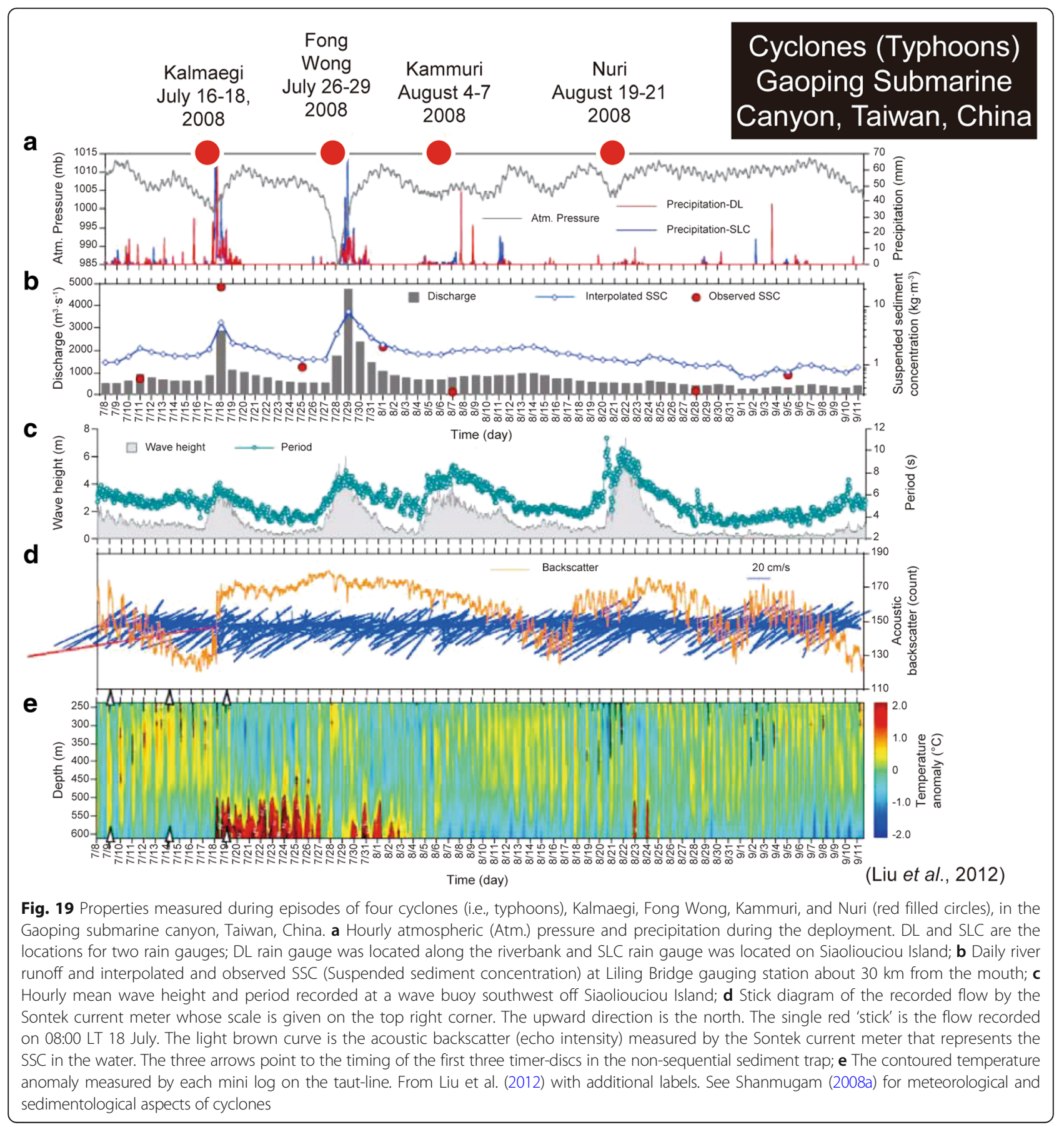


experiments have also shown that turbidity currents composed of pure sand (medium- to coarse-grained) without the fines tend to collapse soon after initiation (Shanmugam 2000). Turbidity currents are capable of transporting mainly mud and very fine-grained sand in suspensions. Therefore, any hypothetical model that advocates lofting of sandy hyperpycnal flows is incongruous with respect to what we know from experiments about the inability of turbidity currents to transport medium-grained sand in suspension.

Finally, both Warrick et al. (2013) and Steel et al. (2016) invoked the origin of sands in the Santa Barbara Channel studies to hyperpycnal flows. But they totally ignored the significance of tidal currents. Tidal currents in the Santa Barbara Channel had been well documented (Münchow 1998). Boyd et al. (2008) convincingly documented that at high sea-level, southeast Australian deep-water sands are delivered by a wave-driven coastal transport system, interacting with estuarine ebb tidal flows that transport sand over the shelf edge. Therefore, one could explain deposition of the so-called "hyperpycnites" in the Santa Barbara Channel by tidal current activities as well.

\section{Submarine canyons}

Submarine canyons play a critical role in serving as conduits for the transfer of sediments from the land to the sea (Shepard 1981; Shepard and Dill 1966). Submarine canyons are also important to understanding conceptual models of hyperpycnites (Fig. 16) because plant remains are used as a

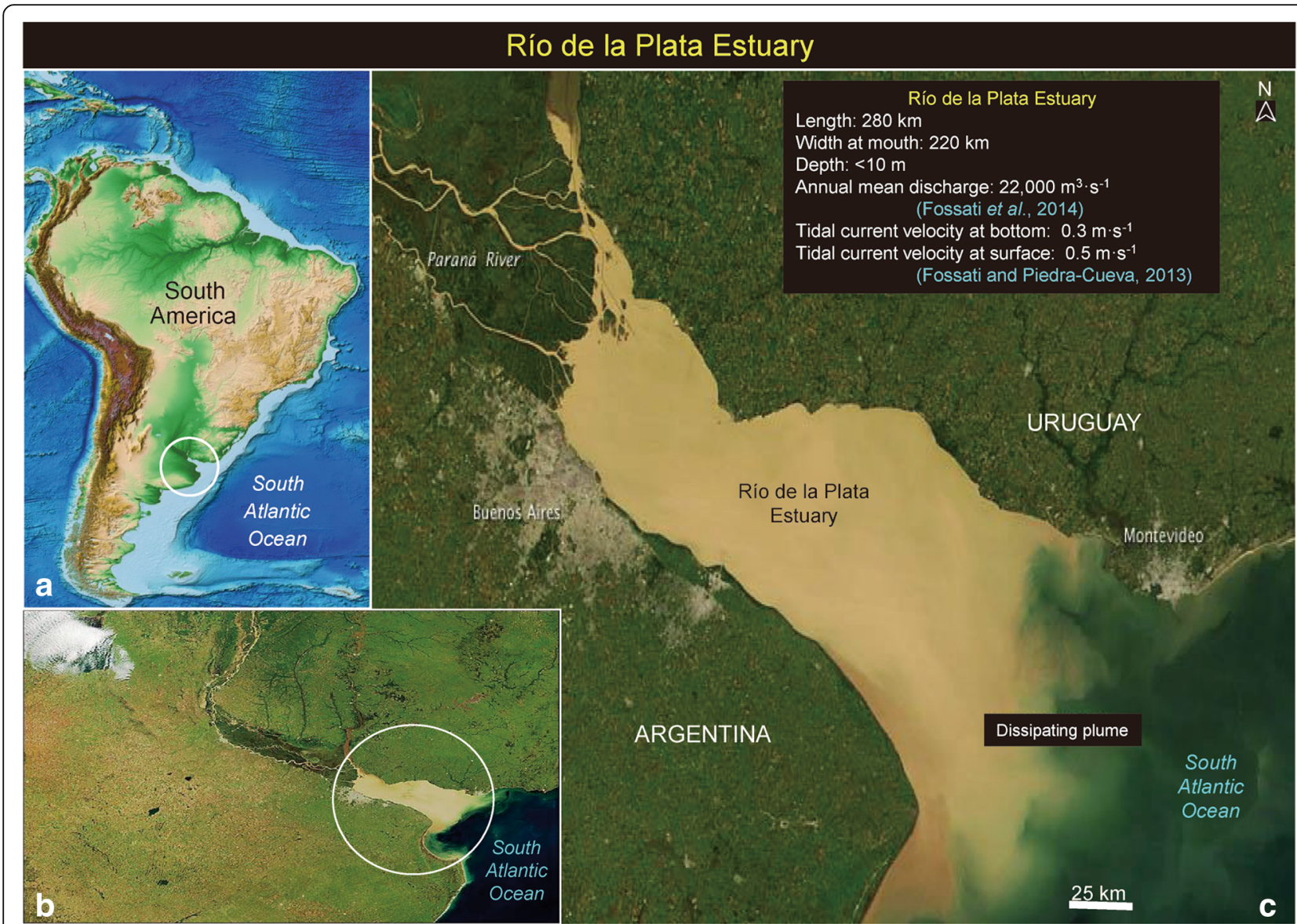

Fig. 20 Río de la Plata Estuary. a Location of the Río de la Plata Estuary (white circle). Image credit: ETOPO1 Global Relief Model, C. Amante and B.W. Eakins, ETOPO1 Arc-Minute Global Relief Model: Procedures, Data Sources and Analysis, NOAA Technical Memorandum NESDIS NGDC-24, March 2009; b Satellite image showing the Río de la Plata Estuary. This image is used as an index map to provide a regional perspective. Image courtesy Jacques Descloitres, MODIS Land Group, NASA GSFC. https://earthobservatory.nasa.gov/IOTD/view.php?id=651. Image acquired on April 24, 2000; c Satellite image showing the Río de la Plata Estuary with hyperpycnal plumes that tend to move towards the Argentinian shelf to the south. Framiňan and Brown (1996) used the term "turbidity front" for this hyperpycnal plume. Note that the entire, 220-km wide, plume gets diluted and dissipated with an irregular front, which fails to advance into the South Atlantic. This dilution of plume is attributed to external controls, such as ocean currents operating on the shelf. The Paraná River, the second longest river in South America after the Amazon, supplies three-quarters of the fresh water that enters the estuary, with the remainder arriving from the Uruguay River. See Fossati and Piedra-Cueva (2013). Image credit: NASA Earth Observatory, NASA image by Jeff Schmaltz, LANCE/EOSDIS MODIS Rapid Response. https://earthobservatory.nasa.gov/IOTD/ view.php?id=77581. Image acquired on March 31, 2012. Additional labels by G. Shanmugam 
criterion to recognize large submarine fans (see Section 6.7). Therefore, it is imperative to acknowledge some fundamental aspects of submarine canyons that are well established.

\subsection{Origin}

Lamb et al. (2010, p. 1398) in their attempt to explain the origin of submarine canyons by hyperpycnal flows stated that "In fact, hyperpycnal flows might erode the seabed, which offers a potentially interesting feedback between plunging hyperpycnal flows and submarine canyon formation (e.g., Pratson et al. 1994)". However, Pratson et al. (1994, p. 411) concluded that "As reviewed here, mass wasting initiated the subsea sediment flows that began canyon formation and enhanced canyon growth by widening the canyons through retrogressive sea-floor failures, for example, the gullying of canyon walls observed by Farre and others (Farre et al. 1983)". Clearly, Pratson et al. (1994) were not referring to hyperpycnal flows because their term "sediment flows" was meant for sediment-gravity flows (Middleton and Hampton 1973).
Sediment-gravity flows are composed of grain flows, debris flows, fluidized sediment flows, and turbidity currents (Middleton and Hampton 1973, their Fig. 1). Sediment flows are not hyperpycnal flows.

Daly's hypothesis for the origin of submarine canyons by density (turbidity) currents was quite popular in the 1950s and 1960s (Daly 1936). F.P. Shepard, who devoted his professional life at the Scripps Institution of Oceanography in California to the study of submarine canyons, concluded that submarine canyons were formed not by a single mechanism, but by a combination of processes, such as subaerial erosion, submarine erosion, and faulting, over a long period of time. The point is that Shepard did not even consider the possibility of hyperpycnal flows in explaining the origin of submarine canyons (Shepard 1981). Brine-related dense shelf-water cascading currents (Roveri et al. 2013) should not be confused with hyperpycnal flows in eroding submarine canyons. Importantly, there are no empirical data to document the erosion of modern seafloor by genuine hyperpycnal flows.

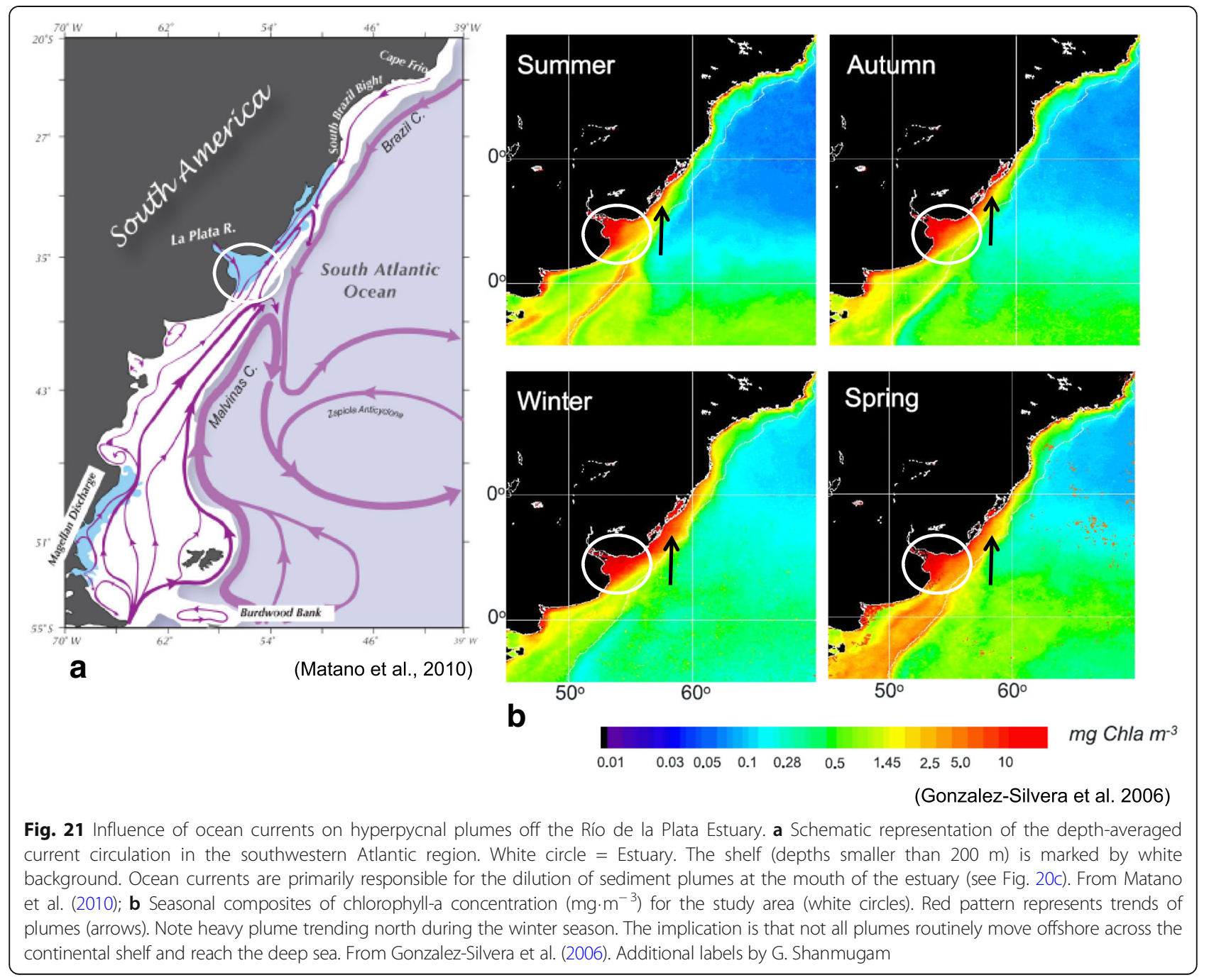




\subsection{Classification}

Submarine canyons are critical for understanding deep-sea sedimentation (Normark and Carlson 2003; Shanmugam 2003; Shepard and Dill 1966; among others). In this regard, Harris and Whiteway (2011), based on ETOPO1 bathymetric grid, compiled the first inventory of 5849 separate large submarine canyons in the world's oceans. They classified canyons into three basic types:

Type 1: Shelf-incising canyons having heads with connection to a major river or estuarine system (Fig. 17);

Type 2: Shelf-incising canyons with no clear connection to a major river or estuarine system (Fig. 18);

Type 3: Slope-incising blind canyons with their heads confined to the continental slope (Fig. 18).

Harris and Whiteway (2011) also reported that canyons exhibit an impressive array of statistics from their length and spacing to their slope, depth range, dendricity, and sinuosity. Active continental margins contain $44.2 \%$ of all canyons (2586/5849) and passive margins contain 38.4\% (2244/5849). Canyons are steeper, shorter, more dendritic, and more closely spaced on active than on passive continental margins. River-associated, shelf incising canyons are more numerous on active continental margins than on passive margins. They are most common on the western margins of South and North America where they comprise $11.7 \%$ and $8.6 \%$ of canyons, respectively. In the Mediterranean Sea, where 518 large submarine canyons have been identified (Harris and Whiteway 2011), all three types of canyons are present. If one wishes to study the role of hyperpcnal flows in causing submarine canyons, one needs to apply these kinds of robust global datasets.

Despite the critical role of submarine canyons in forming submarine fans (Bouma et al. 1985), Zavala and Arcuri (2016) totally ignored the significance of the three types of submarine canyons in their models for hyperpycnite fans. It is worth noting that the Type 1 and Type 3 submarine canyons are likely to serve as conduits for extrabasinal and intrabasinal turbidites, respectively. For example, the Zaire Canyon (Fig. 17), which is a Type 1 canyon, would

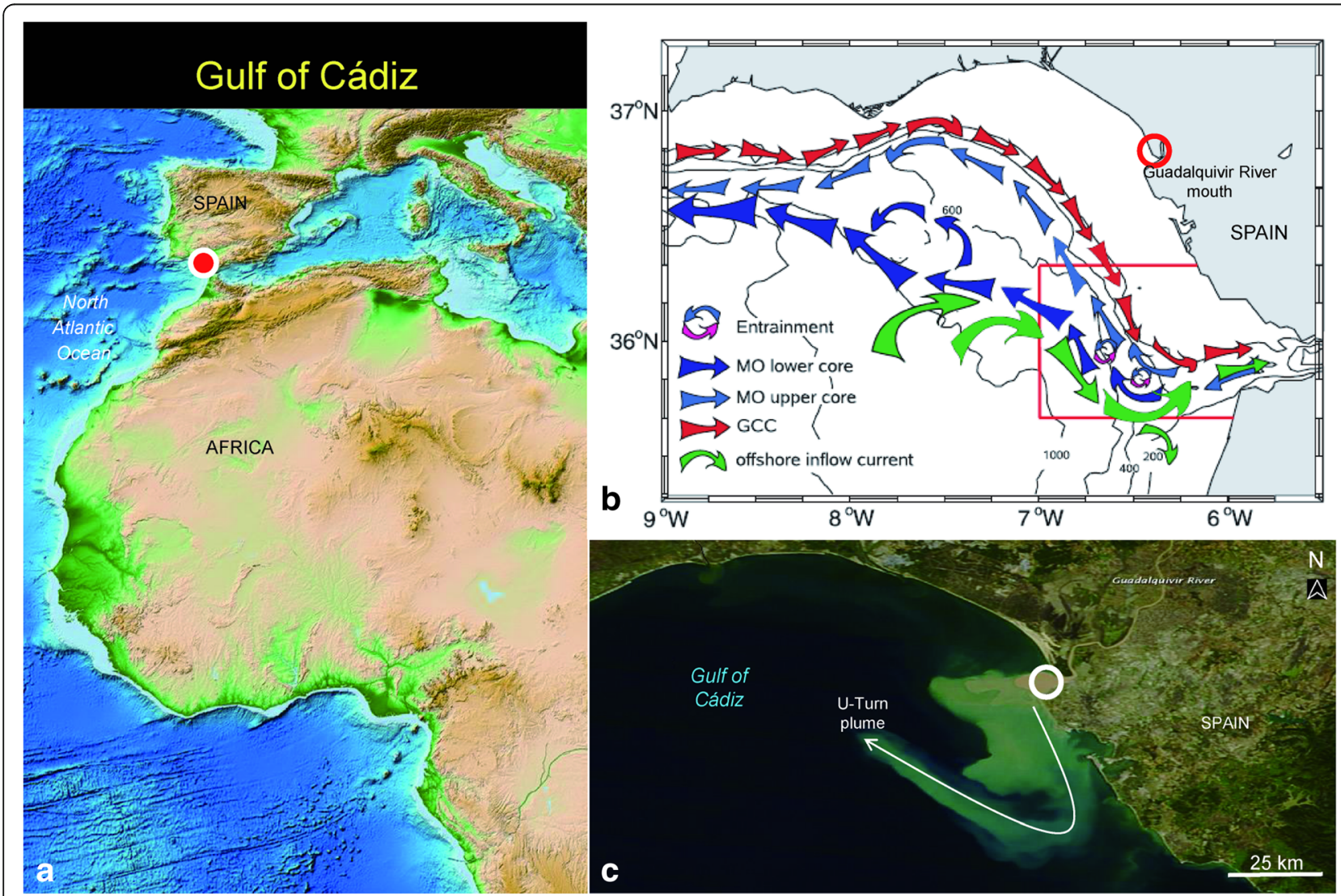

Fig. 22 Gulf of Cádiz. a Location map of the Gulf of Cádiz (red filled circle). Image credit: ETOPO1 Global Relief Model, C. Amante and B.W. Eakins, ETOPO1 Arc-Minute Global Relief Model: Procedures, Data Sources and Analysis, NOAA Technical Memorandum NESDIS NGDC-24, March 2009; b Circulation patterns of ocean currents in the Gulf of Cádiz (Peliz et al. 2009). MO= Mediterranean outflow; GCC = Gulf of Cádiz slope current; c Satellite image showing sediment plumes with an U-Turn pattern (white arrow). Note that the U-Turn pattern is mimicking the circulation of ocean currents (b). White open circle = Guadalquivir River mouth. NASA image courtesy Jeff Schmaltz, LANCE MODIS Rapid Response Team at NASA GSFC. https://earthobservatory.nasa.gov/NaturalHazards/view.php?id=79677. Image acquired on November 13, 2012. Additional symbols and labels all by G. Shanmugam 
serve as a conduit for transport of plant remains from land to the sea, irrespective of the process, be it turbidity currents, tidal currents, or hyperpycnal lows. One could easily misinterpret the Type 1 canyon-fill deposits with plant remains as hyperpycnites, although tidal currents could have transported those plant remains. Shanmugam et al. (2009) interpreted canyon-fill deposits with plant remains as tidalites in the Bay of Bengal.

\subsection{Cyclone-induced hyperpycnal turbidity currents in canyons}

Liu et al. (2012) claimed four episodes of "clone-induced hyperpycnal turbidity currents" in the Gaoping submarine canyon, Taiwan, China (Fig. 19). These cyclones, named Kalmaegi, Fong Wong, Kammuri, and Nuri, occurred during the cyclone (typhoon) season between 8 July and 11 September 2008. Liu et al. (2012) stated that "Our findings verify turbidite sequences with the characteristics of suspended sediment carried by passing turbidity currents that displayed distinct waxing and waning phases. Our study also confirms the direct link between typhoon-triggered hyperpycnal flows in a small mountainous river and turbidity currents in a nearby submarine canyon that transport sediment to the deep-sea efficiently". Cyclones do generate flows that travel in various directions, but they should not be equated with "hyperpycnal flows" for meteorological reasons (Shanmugam 2008a). The other problem is that cyclonic flows can travel in any direction (upslope, downslope, alongslope, even within canyons), whereas hyperpycnal flows travel only downslope (seaward) because they are density flows, unless they are redirected by shelf currents. The appropriate process term here is "cyclone-induced density flows". Palanques et al. (2006) documented the role of cyclones and dense water cascading in the Gulf of Lions submarine canyons.

\section{Configurations of density plumes}

\subsection{Types}

Our current understanding of hyperpycnal flows is based on a skewed emphasis on river-mouth processes. However, a global survey of density plumes suggests a plethora of plume types and origins. For example, the U.S. National Aeronautics and Space Administration

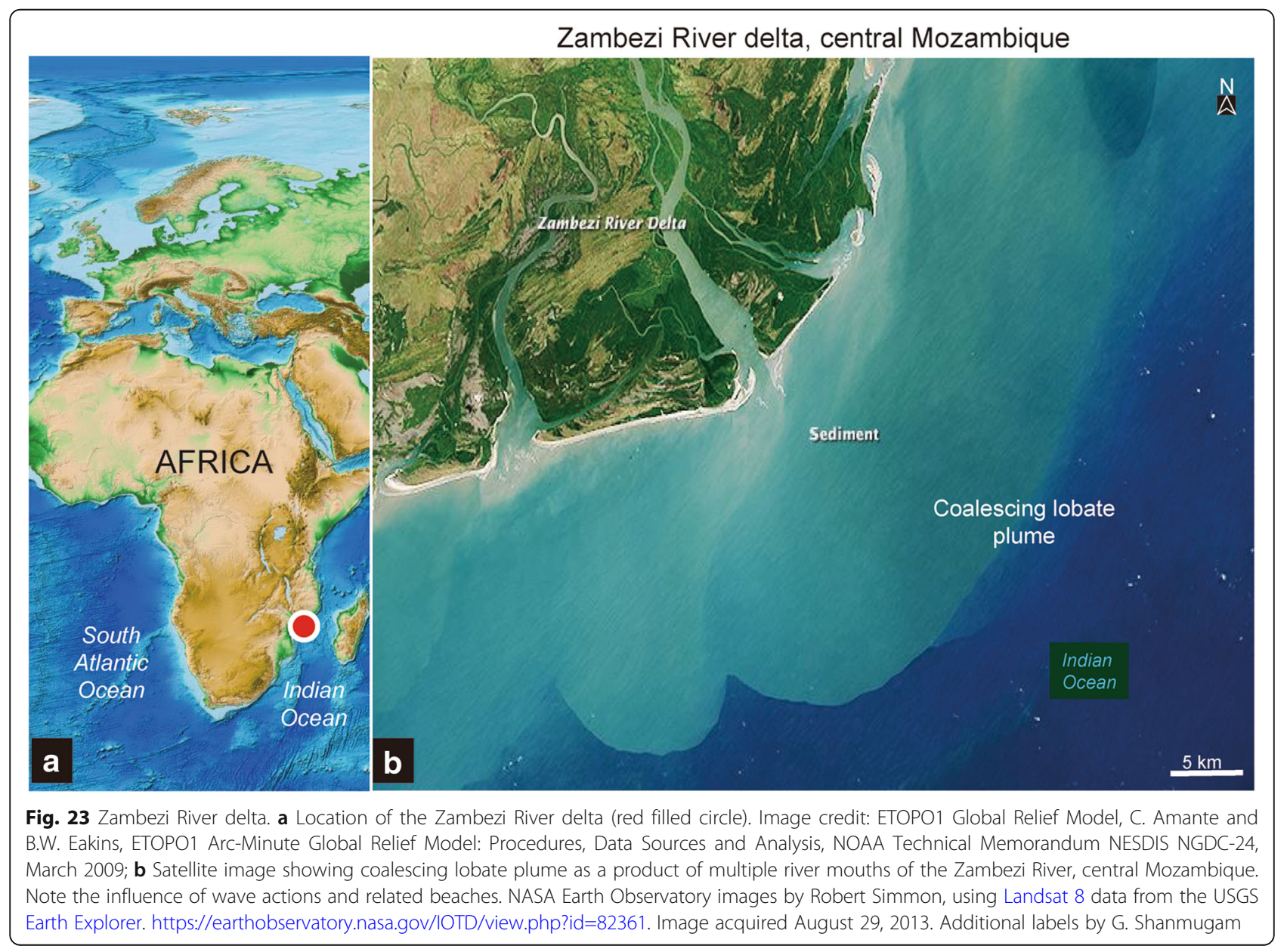


(NASA 2017) has archived thousands of satellite images of density plumes in its online publishing outlet called "Earth Observatory" since 1999. There are, at least, 24 configurations of density plumes (NASA 2017; Table 1):

1) Simple lobate (Fig. 2e),

2) Horse's tail (Fig. 2f),

3) Deflecting (Fig. 11a),

4) Dissipating (Fig. 20c),

5) U-Turn (Fig. 22c),

6) Swirly (Fig. 27b),

7) Cloudy (Shanmugam, 2018b),

8) Massive (Shanmugam, 2018b),

9) Tidal lobate (Fig. 26c),

10) Cascading (Shanmugam, 2018b),

11) Backwash (Shanmugam, 2018b),

12) Meltwater (Shanmugam, 2018b),

13) Coalescing irregular (Fig. 24a),

14) Eolian blanketing dust (Fig. 24b),

15) Linear (Fig. 6),

16) Anastomosing (Fig. 25b),

17) Coalescing lobate (Fig. 23b),

18) Whitings (Shanmugam, 2018b),

19) Ring (Shanmugam, 2018b),

20) Tendril (Fig. 28b),
21) Eolian dust (Shanmugam, 2018b),

22) Feathery (Shanmugam, 2018b),

23) Volcanic ash (Shanmugam, 2018b),

24) Gas hydrate.

Each type is of significance in sedimentary record. However, there are no systematic studies of these plumes and their deposits in modern settings.

\subsection{Global case studies}

In addition to the three case studies discussed earlier (i.e., braid delta from Alaska, river-dominated delta of the Yellow River and tide-dominated estuary of the Yangtze River in China), I have selected the following case studies in understanding the complex factors that control plume types in estuaries, rivers, bays, and lakes.

\subsubsection{Dissipating plume with irregular front: The Río de la Plata estuary, Argentina and Uruguay, South Atlantic Ocean} The Río de la Plata Estuary is located on the east coast of South America, bordering Argentina and Uruguay. It is one of the largest estuaries in the world (Acha 2008; Fossati et al. 2014; Framiňan and Brown 1996; Sepúlveda et al. 2004). It is $280 \mathrm{~km}$ long and $220 \mathrm{~km}$ wide at its mouth, and its water depth does not exceed $10 \mathrm{~m}$

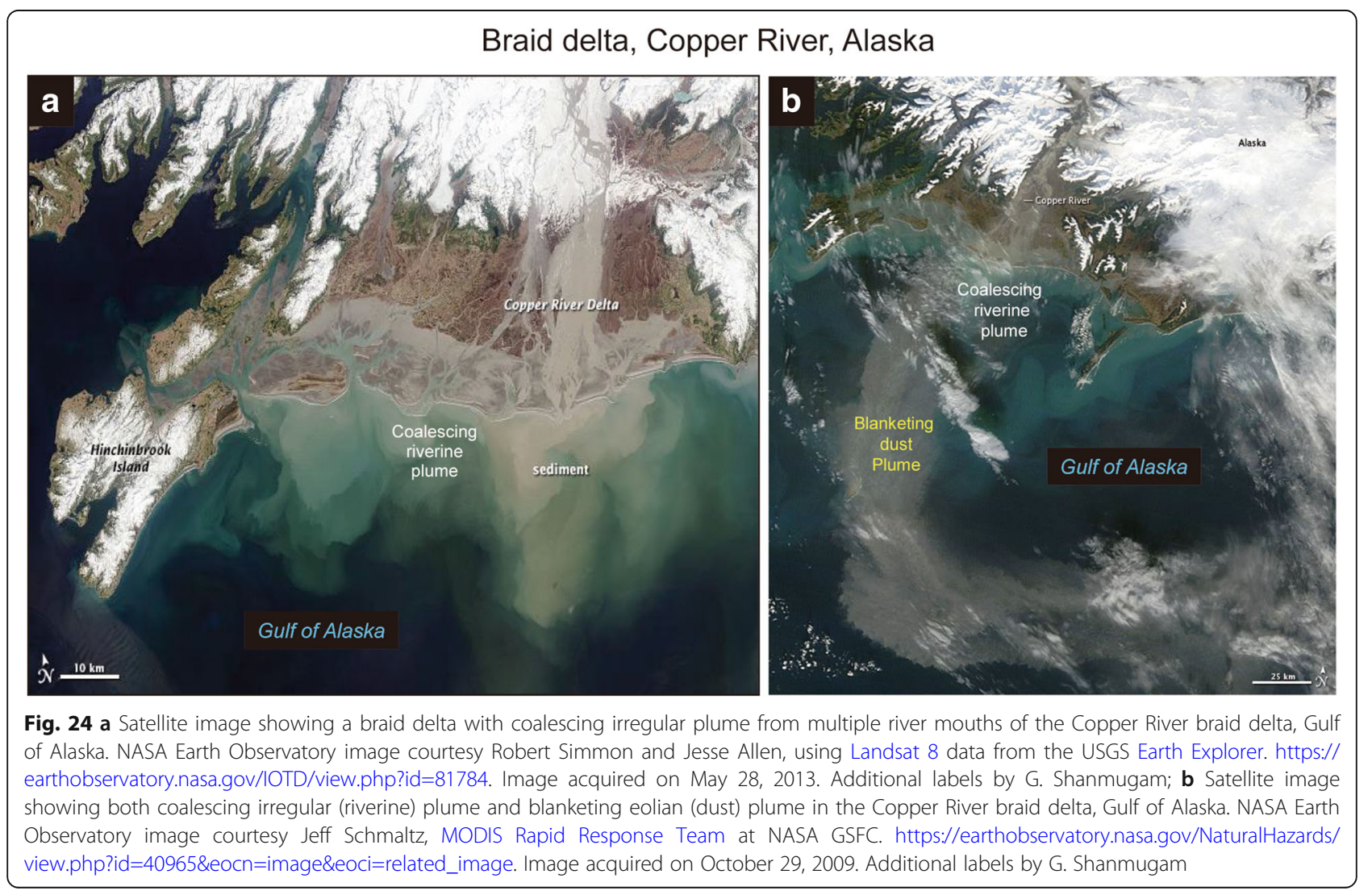


(Fig. 20b). It receives water and sediment from both the Paraná and Uruguay rivers with an annual mean discharge of $22,000 \mathrm{~m}^{3} \cdot \mathrm{s}^{-1}$. Satellite images show dissipating plume with an irregular front (Fig. 20c).

Gonzalez-Silvera et al. (2006) studied ocean color (OCTS, SeaWiFS) and sea surface temperature (AVHRR) images and evaluated spatial and temporal variability of the Brazil-Malvinas Confluence and La Plata Plume $\left(20^{\circ}-45^{\circ} \mathrm{S}\right.$ and $\left.40^{\circ}-65^{\circ} \mathrm{W}\right)$. The data set covered the period from January 1997 to June 2003. Chlorophyll and SST data were compiled and analyzed. The results show a gradual increase of the northward intrusion of the La Plata Plume throughout the period lasting from summer to winter; the summer shape of the La Plata Plume showed a stronger penetration over the shelf on the Argentinean side of the estuary mouth; and the seasonal migration of the Brazil-Malvinas Confluence (Fig. 21). The implications of this study are:
1) In some cases, both sediment plumes and planktonic plumes operate.

2) This dataset strongly suggests the direct control of the sediment plume by ocean currents (Fig. 21a). For example, sediment plumes are diluted and dissipated to virtually nothing at the estuary mouth (Fig. 20c).

3) The seaward transport of planktonic plumes is diverted northward along the inner shelf by seasonal variations (Fig. 21b). Therefore, one should not assume that all plumes transport sediment across the continental shelf and deliver sediment into the deep sea.

4) In cases like this with multiple external controlling factors, use of plant remains as a criterion for recognizing ancient hyperpycnites (Zavala and Arcuri 2016) is meaningless.

5) The Río de la Plata plume, sourced primarily by the Paraná River, is in direct conflict with a theoretical

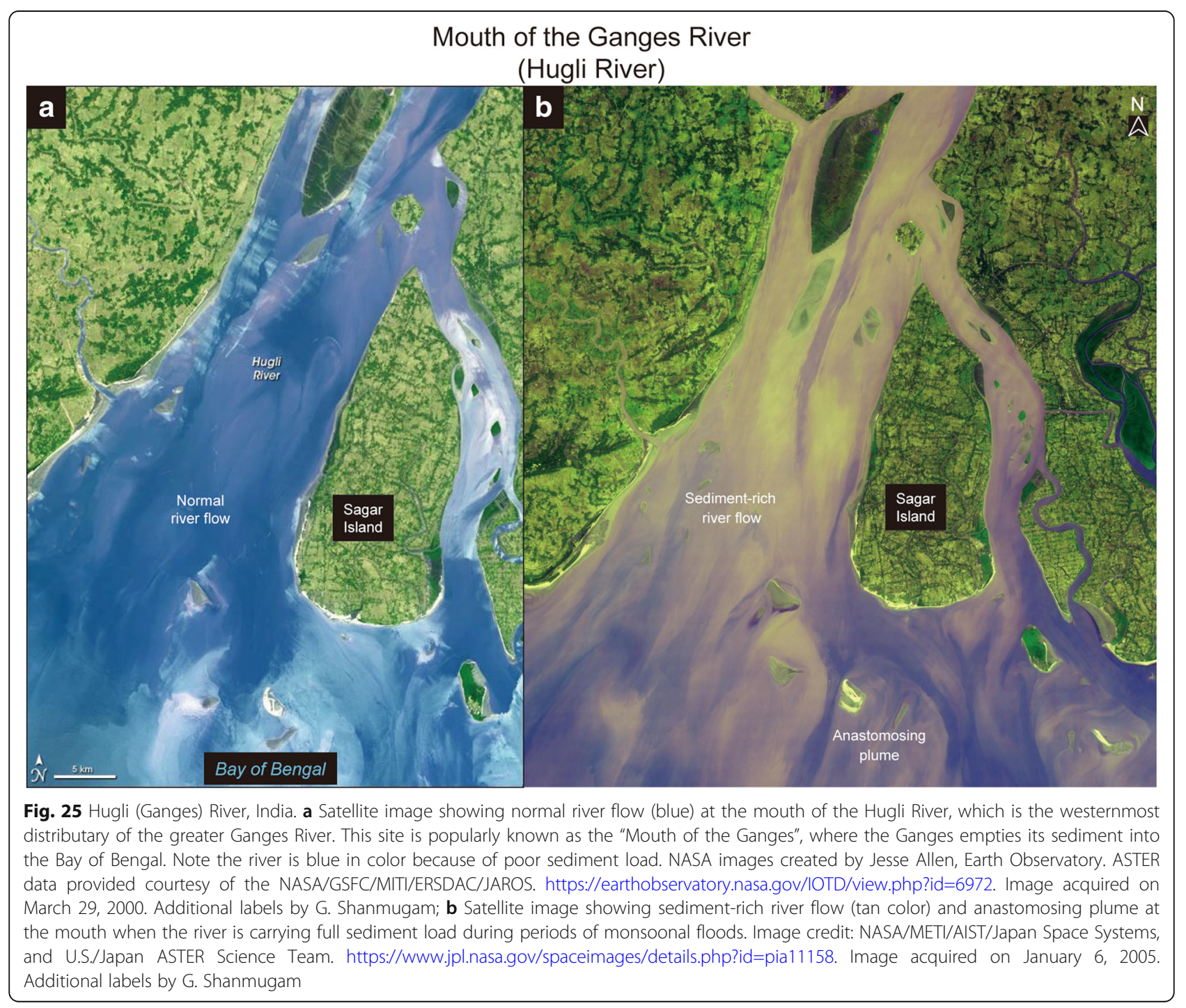


hypothesis by Mulder et al. (2003, their Table 5) who argued that the Paraná River "cannot" generate hyperpycnal flows. Similarly, Mulder et al. (2003) also included the Zaire River in West Africa as one of those rivers that cannot trigger hyperpycnal flows. However, studies showed that the Zaire River indeed developed hyperpycnal flows (Migeon 2000). Clearly, the field observations do not support theoretical models.

\subsubsection{U-turn plume: Guadalquivir River, Gulf of Cádiz, North Atlantic Ocean}

The Gulf of Cádiz is located in the northeastern Atlantic Ocean (Fig. 22a). It is enclosed by the southern Iberian and northern Moroccan margins, west of the Gibraltar Strait. Two major rivers, the Guadalquivir and the Guadiana, as well as smaller rivers, like the Odiel, the Tinto, and the Guadalete, reach the ocean here. In terms of ocean currents (Peliz et al. 2009), it is one of the most complex oceanographic settings (Fig. 22b). Mimicking the current patterns, sediments that are emptied into the gulf by the Guadalquivir River exhibit an U-Turn shape for the plume (Fig. 22c). In cases like this, one must consider the influence of ocean currents on the dispersal of hyperpycnite sediments. The problem is that how these hyperpycnite sediments would dffier from those hyperpycnites unaffected by ocean currents. In other words, do plume

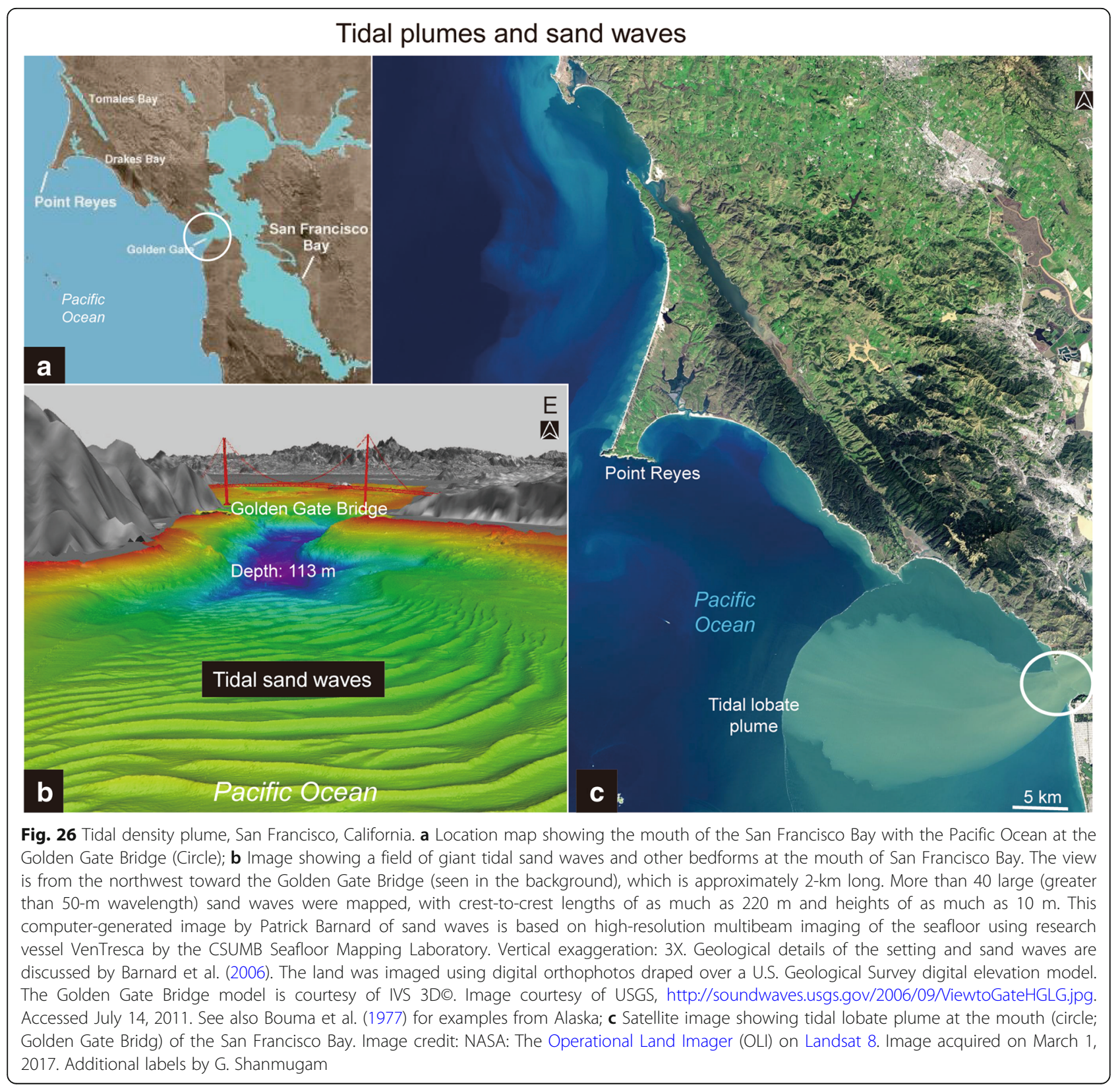


configurations (i.e., U-Turn versus lobate) matter in the depositional record? No one has addressed this issue.

\subsubsection{Coalescing lobate plume: Zambezi River, Indian Ocean}

The Zambezi River in Central Mozambique is a wave-dominated delta. It has developed a coalescing lobate plume due to multiple river mouths (Fig. 23b). The importance of longshore currents in modifying the delta is discussed by Mikhailov et al. (2015).

\subsubsection{Coalescing and blanketing plumes: Copper River braid delta, Gulf of Alaska, Pacific Ocean}

Galloway (1976) originally classified the Copper River delta as a "fan delta". According to McPherson et al.
(1987), the Copper River delta fits the characteristics of coarse-grained braid delta. The importance here is that it develops both coalescing irregular plume (Fig. 24a) and blanketing eolian dust plume (Fig. 24b). In cases like this, it is extremely difficult to distinguish the complex interaction between riverine and eolian input by examining depositional record.

\subsubsection{Anastomosing plume: Hugli River, India, Bay of Bengal} The Hugli River is a distributary of the Ganges River that empties its sediments into the Bay of Bengal. During monsoonal flood stages, the Hugli River develops anastomosing plumes at the mouth (Fig. 25b). The Ganges River mouth is considered as a tide-dominated estuary (Balasubramanian and Ajmal Khan 2002).

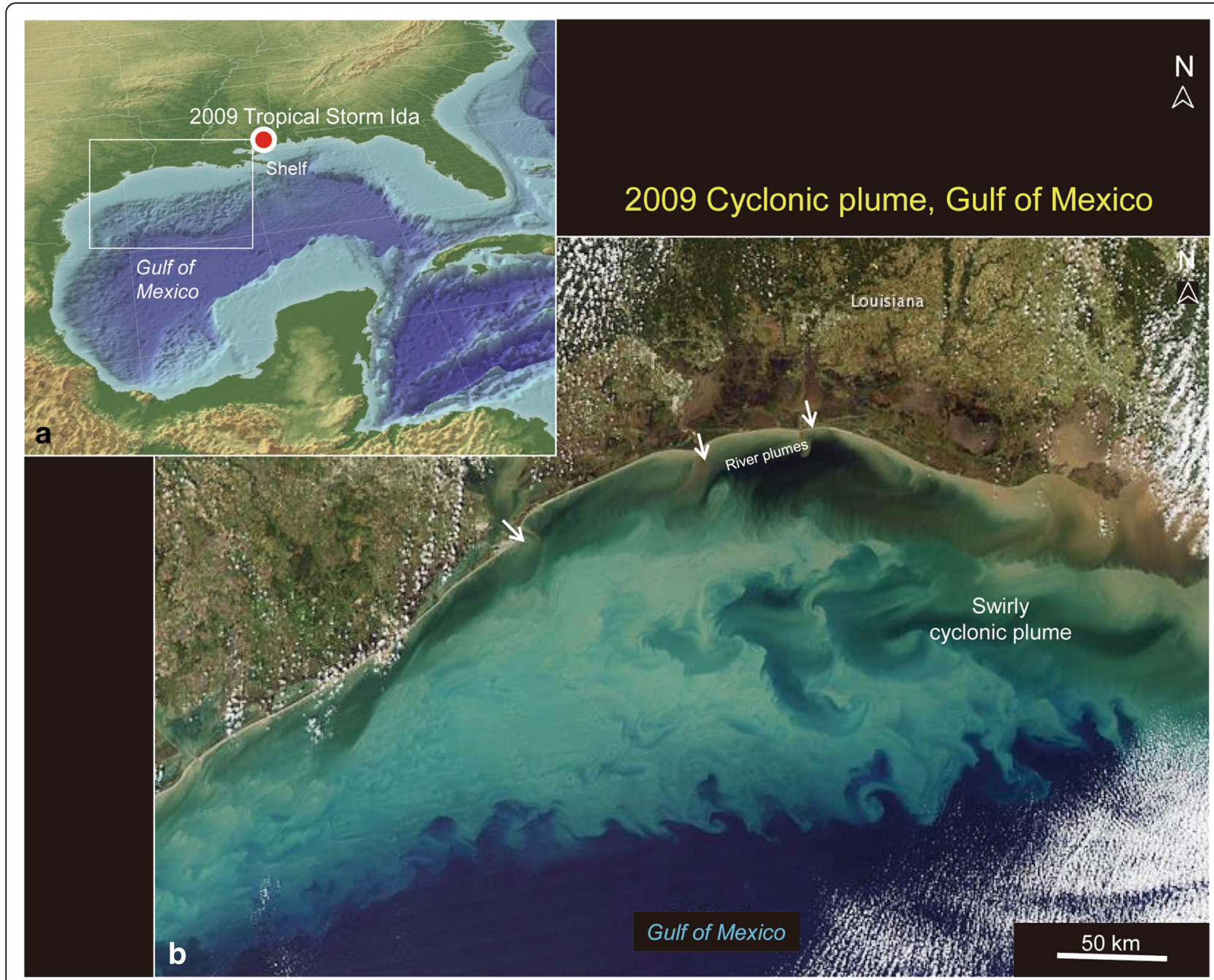

Fig. 27 Cyclones in the Gulf of Mexico. a Location map showing position of Tropical Storm Ida (red filled circle) that came ashore on November 10, 2009; b Satellite image showing swirly cyclonic plume occupying the entire shelf area in the northern Gulf of Mexico. Small white arrows = River mouths. NASA images courtesy Jeff Schmaltz, MODIS Rapid Response Team at NASA GSFC. https://earthobservatory.nasa.gov/IOTD/view.php?id=41237 \&eocn=image\&eoci=related_image. Image acquired on November 10, 2009, just a few hours after the storm hit Alabama and Florida. Unlike riverine hyperpycnal plumes, transport of gravel, sand, and mud to deep-water environments by cyclone-related flows is possible. Additional labels by G. Shanmugam 


\subsubsection{Tidal lobate plume: San Francisco Bay, Pacific Ocean} The Golden Gate Bridge is located at the mouth of the San Francisco Bay connecting the Pacific Ocean (Fig. 26a). Barnard et al. (2006) reported a field of giant sand waves of tidal origin beneath the Golden Gate Bridge at the mouth of San Francisco Bay in California (Fig. 26b). Repeated surveys demonstrated that the sand waves are active and dynamic features that move in response to tidally generated currents. The significance of the tidal sand waves at the mouth of the San Francisco Bay is that muddy lobate sediment plumes have been imaged by NASA at this area (Fig. 26c). The oceanographic significance here is that these tidal lobate plumes are identical in shape to classic river-mouth sediment plumes, such as the one observed at the mouth of the Yellow River (Fig. 2e). Does it mean that tidal lobes and river-flood lobes would generate identical depositional sequences?

\subsubsection{Swirly cyclonic plume: Northern Gulf of Mexico}

Although rivers supply sediments into the northern Gulf of Mexico, cyclones frequently resuspend muddy sediments over the entire shelf. For example, the 2009 Tropical Storm Ida resuspended muddy sediments and caused a swirly cyclonic plume that is nearly $150 \mathrm{~km}$ in maximum width in the northern Gulf of Mexico (Fig. 27b). Such catastrophic plumes tend to mask any smaller plumes induced by rivers. But there are no studies differentiating depositional characteristics of cyclonic plumes from those of riverine plumes.

\subsubsection{Tendril plume: Lake Michigan, USA}

Satellite image shows tendril configuration of plumes in Lake Michigan (Fig. 28b). In this example, suspended sediments transformed the southern end of Lake Michigan. Ranging in color from brown to

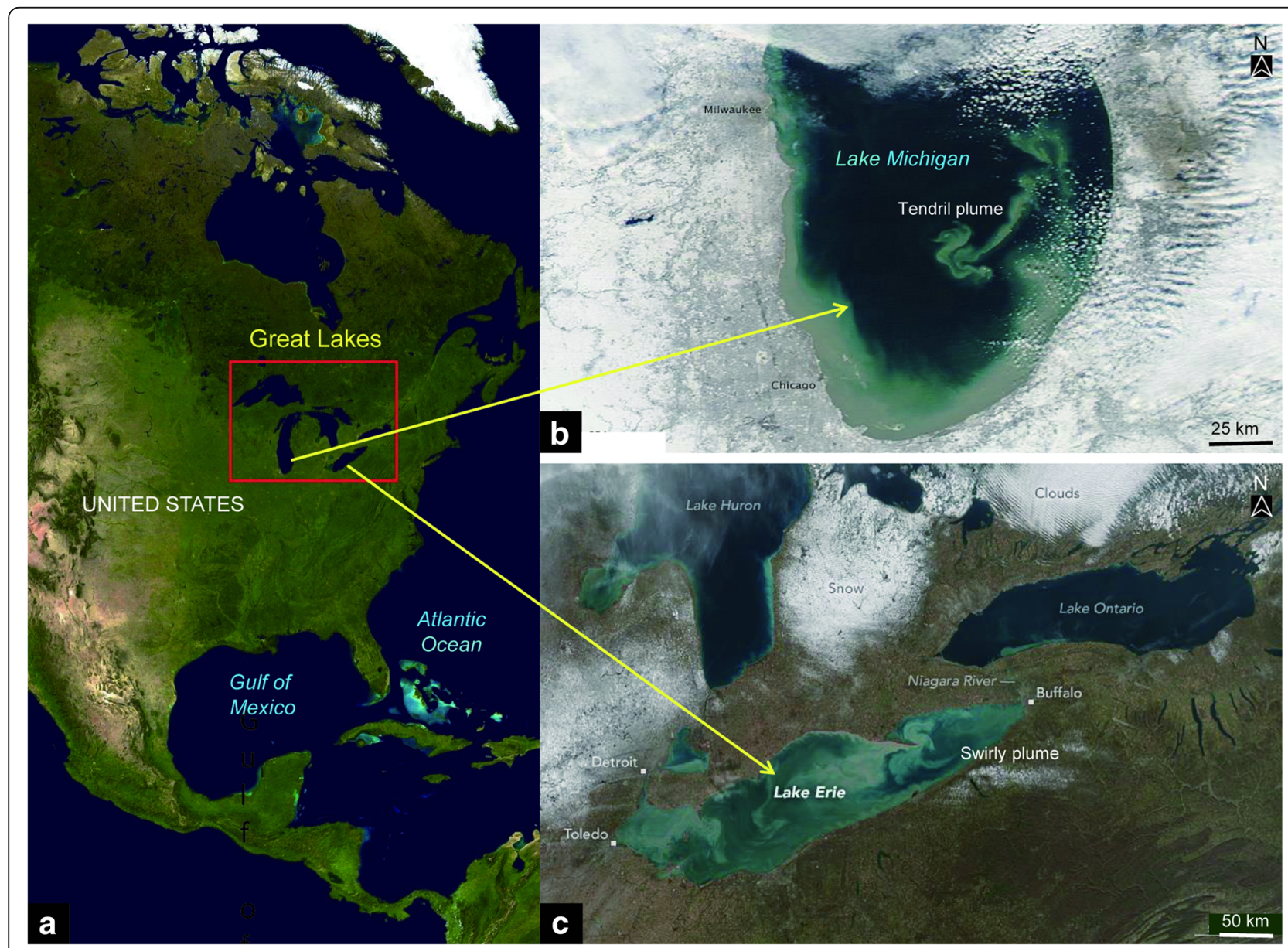

Fig. 28 Density plumes in lakes. a Great Lakes, United Staes. Image: Wikipedia; b Satellite image showing a tendrill plume in Lake Michigan. NASA image courtesy MODIS Rapid Response Team at NASA GSFC. https://earthobservatory.nasa.gov/IOTD/view.php?id=48511. Image acquired on December 17, 2010; c Satellite image showing swirly plume induced by seiche in Lake Erie. NASA Earth Observatory image by Jesse Allen, using VIIRS data from the Suomi National Polar-orbiting Partnership. Suomi NPP is the result of a partnership between NASA, the National Oceanic and Atmospheric Administration, and the Department of Defense. https://earthobservatory.nasa.gov/IOTD/view.php?id=87079. Image acquired on November 25, 2015. Additional labels by G. Shanmugam 
green, the sediment filled the surface waters along the southern coastline and formed a long curving tendril extending toward the middle of the lake, induced by wind activity.

\subsubsection{Swirly plume: Lake Erie, USA}

Swirly plumes in Lake Erie, USA were attributed seiche (NASA 2017; Fig. 28c). Seiche is a large standing wave that occurs when strong winds and a quick change in atmospheric pressure push water from one end of a body of water to the other. de Jong and Battjes (2004) discussed the atmospheric origin of seiche.

\subsubsection{Challenges}

Twenty-four types of plumes are broadly grouped into 14 common categories (Fig. 29). Configurations of density plumes are controlled not only by river floods, but also by tidal currents, ocean currents, upwelling, tsunamis, cyclones, seiche, volcanism, fish activity, coral reef, etc. Despite their wide natural variability in triggering mechanisms, only riverine plumes have received the primary attention thus far. The challenge in studying density plume is that a single type (e.g., swirly) can be generated by different mechanisms (e.g., cyclone, seiche, upwelling, etc.). To date, no one has investigated how these different types of density plumes are preserved in the sedimentary record. Amid these uncertainties, it is premature to propose a facies model for hyperpycnites based on the false notion that there is only one type of hyperpycnal flow, which is the river-mouth type. The other issue is that these different plumes are composed mostly of suspended mud and
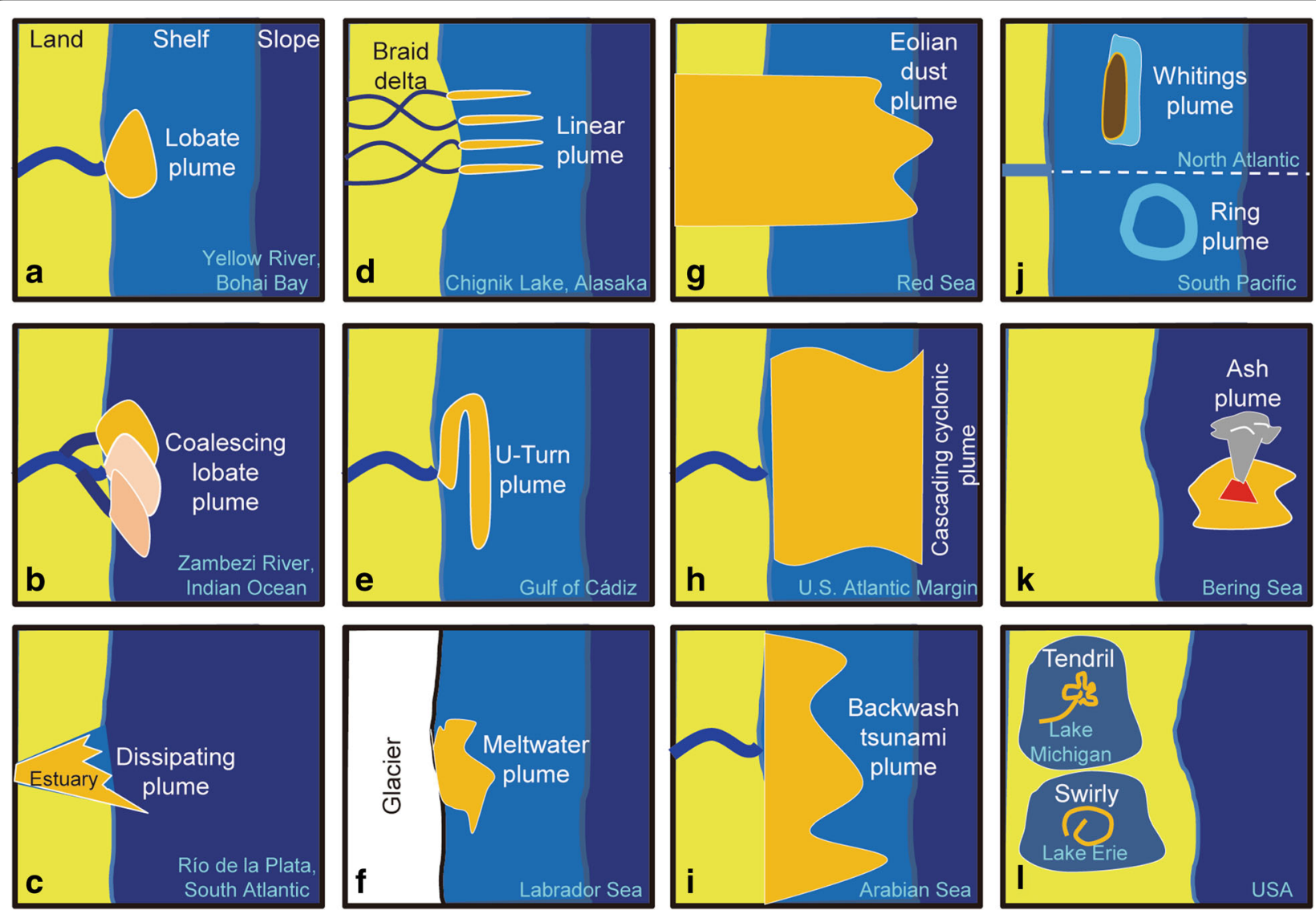

Fig. 29 Summary diagram showing 14 general types of plumes that include 12 marine examples and two lacustrine examples. a Lobate plume developed by a single river channel; b Coalescing lobate plume developed by multiple river channels; c Dissipating plume with an irregular front developed within a major estuary; $\mathbf{d}$ Linear plume developed in a braid delta e U-Turn plume developed in response to influence by ocean currents; $\mathbf{f}$ Meltwater plume developed from glacier; $\mathbf{g}$ Dust plume from eolian processes that can transport dust beyond the shelf edge; $\mathbf{h}$ Cascading plume developed during cyclones that tend to transport sediment (gravel, sand and mud) beyond the shelf break (Shanmugam 2008a); i Backwash plume developed during tsunamis that tend to transport sediment (gravel, sand and mud) beyond the shelf break (Shanmugam 2006b); j Whitings plume and ring plume developed in carbonate environments; k Ash plume developed during volcanic eruptions; I Tendril and swirly plumes developed in lakes. Note that with the exception of cyclones and tsunamis, none of the other plumes can transport sand and gravel to the deep sea by bedload mode. Although these different types can be recognized on modern systems using satellite or other photographic images, individual types cannot be distinguished in the ancient sedimentary record yet 
may be ephemeral. Therefore, there is an immediate need to evaluate these long-ignored plume types and their deposits.

\section{Concluding remarks and future directions}

A global evaluation of density plumes suggests a complex variability in nature (Fig. 30), which includes (1) six different environments, (2) six compositional material, (3) 11 sources, (4) 15 external controls, and (5) 24 types. Therefore, it is not meaningful to adopt a single facies model for riverine hyperpycnites (Fig. 14a). In short, the hyperpycnite facies model (Fig. 14a) is obsolete.

Students' research in the future could benefit from the following objectives and guidelines:

1) Apply meaningful process terms in studying density plumes.

2) Avoid equating hyperpycnal lows with turbidity currents.

3) Conduct laboratory flume experiments by using natural sea water as standing body of water.

4) Realize that density plumes originate not only at plunge points associated with rivers, but also in sites unrelated to plunge points (e.g., open marine, away from the shoreline).
5) Measure physical properties of hyperpycnal flows at plunge points in modern marine environments (e.g., water depth, gradient change, flow velocity, sediment concentration, seafloor erosion, initiation of turbidity currents, etc.).

6) Acquire empirical data on hyperpycnal flows and their ability to transport sand and gravel in suspension across the modern continental shelf.

7) Investigate the link between plume types and their depositional characteristics in various settings influenced by tidal currents, glacial meltwater, eolian dust, volcanic ash, tsunamis, cyclones, upwelling, etc.

8) Keep in mind that popular facies models of the twentieth Century, associated with turbidites (Shanmugam 1997; Van der Lingen 1969), tsunamites (Shanmugam 2006b), contourites (Shanmugam 2016b), seismites (Shanmugam 2016c), and hyperpycnites (this paper), are all problematic in the end. Learn from history and resist the temptation of building genetic facies models.

Finally, I would like to conclude this article with an optimistic note for students. Amid numerous obstacles that exist on studies of density plumes, opportunities also exist for initiating M.S.- and Ph.D.-level researh projects. The reason is that an enormous number of

\begin{tabular}{|c|c|c|c|c|}
\hline Environment & Composition & Provenance & External Control & Type \\
\hline $\begin{array}{l}\text { 1. Marine } \\
\text { 2. Lacustrine } \\
\text { 3. Estuarine } \\
\text { 4. Lagoon } \\
\text { 5. Bay } \\
\text { 6. Reef }\end{array}$ & $\begin{array}{l}\text { 1. Siliciclastic } \\
\text { 2. Calciclastic } \\
\text { 3. Volcaniclastic } \\
\text { 4. Planktonic } \\
\text { 5. Hydrogen } \\
\text { sulfide } \\
\text { 6. Gas hydrate }\end{array}$ & $\begin{array}{l}\text { 1. River flood } \\
\text { 2. Common delta } \\
\text { 3. Braid delta } \\
\text { 4. Tidal estuary } \\
\text { 5. Subglacial } \\
\text { 6. Eolian } \\
\text { 7. Volcanic } \\
\text { 8. Planktonic } \\
\text { 9. Carbonate } \\
\text { platform } \\
\text { 10. Hydrogen } \\
\text { sulfide } \\
\text { 11. Gas hydrate }\end{array}$ & $\begin{array}{l}\text { 1. Tidal shear front } \\
\text { 2. Ocean current } \\
\text { 3. Tidal current } \\
\text { 4. Monsoonal } \\
\text { current } \\
\text { 5. Wave action } \\
\text { 6. Cyclone } \\
\text { 7. Tsunami } \\
\text { 8. Braid delta } \\
\text { 9. Seiche } \\
\text { 10. Upwelling } \\
\text { 11. Fish activity } \\
\text { 12. Volcanism } \\
\text { 13. Coral reef } \\
\text { 14. Pockmarks } \\
\text { 15. Internal waves } \\
\text { and tides }\end{array}$ & $\begin{array}{l}\text { 1. Simple lobe } \\
\text { 2. Horse's tail } \\
\text { 3. Deflecting } \\
\text { 4. Dissipating } \\
\text { 5. U-Turn } \\
\text { 6. Swirly } \\
\text { 7. Cloudy } \\
\text { 8. Massive } \\
\text { 9. Tidal lobe } \\
\text { 10. Cascading } \\
\text { 11. Backwash } \\
\text { 12. Meltwater } \\
\text { 13. Coalescing irregular } \\
\text { 14. Blanketing } \\
\text { 15. Linear } \\
\text { 16. Anastomosing } \\
\text { 17. Coalescing lobate } \\
\text { 18. Whitings } \\
\text { 19. Ring } \\
\text { 20. Tendril } \\
\text { 21. Eolian dust } \\
\text { 22. Feathery } \\
\text { 23. Volcanic ash } \\
\text { 24. Gas hydrate }\end{array}$ \\
\hline
\end{tabular}

Fig. 30 Summary diagram showing complex natural variability of plumes in terms of their environmental settings, their composition, their source, their external control, and types. See Table 1 for specific case studies and related references. This compilation of factors should be considered preliminary. For example, gas hydrate is included in more than one category. Additional studies are needed. See a companion paper using 45 case studies (Shanmugam, 2018b) 
satellite images are available from various modern marine and lacustrine environments (Shanmugam 2018b).

\author{
Acknowledgements \\ I thank Prof. Zeng-Zhao Feng (Editor-in-Chief of the Journal of Palaeogeography; \\ China University of Petroleum, Beijing) for his detailed critical comments that \\ improved the quality of this paper considerably. I also thank Prof. Zeng-Zhao \\ Feng who actively carries out the policy of "A hundred flowers blossom and a \\ hundred schools of thought contend". I sincerely thank Prof. B. Charlotte Schreiber \\ (University of Washington, Seattle) for her no-nonsense, critical, and helpful re- \\ view comments. This paper is an expanded version of the original submission \\ entitled "The hype of hyperpycnal flows". As always, I am thankful to my wife \\ Jean for her general comments. \\ I am grateful to the U.S. National Aeronautics and Space Administration (NASA) \\ for their excellent collection of satellite and other images of sediment plumes \\ triggered by river, tide, glacier, volcanic eruptions, cyclones, etc. I would like to \\ acknowledge the following publishers, governmental and non-govenmental \\ agencies, journals, and colleagues, for their help in granting permissions either \\ formally or through their publication policies to reuse images: \\ 1) American Association of Petroleum Geologists (AAPG), \\ 2) American Geophysical Union (AGU), \\ 3) Cambridge Core and Global-Science Press, \\ 4) Copyright Clearance Center (CCC), Rightslink, \\ 5) Elsevier, \\ 6) European Geosciences Union (EGU), \\ 7) Geological Society of America (GSA), \\ 8) Geological Society of London (GSL), \\ 9) Indian Journal of Geo-Marine Sciences (IJMS), \\ 10) J. G. McPherson, \\ 11) John Wiley and Sons, \\ 12) The U.S. National Aeronautics and Space Administration (NASA), \\ 13) The U.S. National Geophysical Data Center (NGDC), \\ 14) R. D. Kreisa, \\ 15) Society for Sedimentary Geology (SEPM) \\ 16) Springer Nature, \\ 17) The U.S. Army Corps of Engineers, \\ 18) The U.S. Geological Survey (USGS), and, \\ 19) Wikipedia.
}

\section{Authors' contributions}

The author read and approved the final manuscript.

\section{Competing interests}

The author declares that he has no competing interests.

\section{Publisher's Note}

Springer Nature remains neutral with regard to jurisdictional claims in published maps and institutional affiliations.

Received: 11 September 2017 Accepted: 2 January 2018

Published online: 02 August 2018

\section{References}

Acha, E. 2008. An overview of physical and ecological processes in the Río de la Plata Estuary. Continental Shelf Research 28 (13): 1579-1588.

Allen, J.R.L. 1985. Loose-boundary hydraulics and fluid mechanics, selected advances since 1961. In Sedimentology, recent developments and applied aspects, ed. P.J. Brenchley and P.J. Williams, 7-28. Oxford: Blackwell Scientific Publications Published for the Geological Society.

Arnau, P., C. Liquete, and M. Canals. 2004. River mouth plume events and their dispersal in the northwestern Mediterranean Sea. Oceanography 17 (3): 23-31.

Assireu, A.T., E. Alcântara, E.M.L.M. Novo, F. Roland, F.S. Pacheco, J.L. Stech, and J. A. Lorenzzetti. 2011. Hydro-physical processes at the plunge point: An analysis using satellite and in situ data. Hydrology and Earth System Sciences 15 (12): 3689-3700.

Bagnold, R.A. 1954. Experiments on a gravity free dispersion of large solid spheres in a Newtonian fluid under shear. Proceedings of the Royal Society, Series A, Mathematical, Physical \& Engineering Sciences 225: 49-63.
Bagnold, R.A. 1962. Auto-suspension of transported sediment; turbidity currents. Proceedings of the Royal Society, Series A, Mathematical, Physical \& Engineering Sciences 265: 315-319.

Balasubramanian, T., and S. Ajmal Khan. 2002. Estuaries of India. Environmental information system Centre, Centre of Advanced Study in marine biology, Annamalai University, Parangipettai-608 502, Tamil Nadu, India, sponsored by the Ministry of Environment \& forests, government of India, 195. New Delhi: ENVIS Publication Series: 1/2002

Barnard, P.L., D.M. Hanes, D.M. Rubin, and R.G. Kvitek. 2006. Giant sand waves at the mouth of San Francisco Bay. Eos, Transactions American Geophysical Union 87 (29): 287-289.

Bates, C.C. 1953. Rational theory of delta formation. AAPG Bulletin 37 (9): 2119-2162.

Bhattacharya, J., and J. MacEachern. 2009. Hyperpycnal rivers and prodeltaic shelves in the cretaceous seaway of North America. Journal of Sedimentary Research 79: 184-209.

Bi, N.S., Z.S. Yang, H.J. Wang, B.Q. Hu, and Y.J. Ji. 2010. Sediment dispersion pattern off the present Huanghe (Yellow River) subdelta and its dynamic mechanism during normal river discharge period. Estuarine, Coastal and Shelf Science 86 (3): 352-362.

Bouma, A.H. 1962. Sedimentology of some flysch deposits: a graphic approach to facies interpretation, 168. Amsterdam/New York: Elsevier.

Bouma, A.H., M.A. Hampton, and R.C. Orlando. 1977. Sand waves and other bedforms in lower cook inlet, Alaska. Marine Geotechnology 2: 291-308.

Bouma, A.H., W.R. Normark, and N.E. Barnes. 1985. Submarine fans and related Turbidite systems, 351. New York: Springer-Verlag.

Boyd, R., K. Ruming, I. Goodwin, M. Sandstrom, and C. Schröder-Adams. 2008. Highstand transport of coastal sand to the deep ocean: A case study from Fraser Island, Southeast Australia. Geology 36: 15-18.

Breien, H., F.V. De Blasio, A. Elverhøi, J.P. Nystuen, and C.B. Harbitz. 2010. Transport mechanisms of sand in deep-marine environments - Insights based on laboratory experiments. Journal of Sedimentary Research 80: 975-990.

Broecker, W.S., A. Sanyal, and T. Takahashi. 2000. The origin of Bahamian Whitings revisited. Geophysical Research Letters 27 (22): 3759-3760.

Buatois, L. A., L. L. Saccavino, and C. Zavala, 2011. Ichnologic signatures of hyperpycnal flow deposits in Cretaceous river-dominated deltas, Austral Basin, southern Argentina, in R. M. Slatt and C. Zavala, eds., Sediment transfer from shelf to deep water-Revisiting the delivery system: AAPG Studies in Geology 61, pp. 153-170.

Chen, J.Y., H.T. Shen, and C.X. Yun. 1998. Processes of dynamics and geomorphology of the Changjiang estuary, 453. Shanghai: Shanghai Scientific and Technical Publishers (in Chinese with English Abstract).

Chen, S., R.J. Steel, J.F. Dixon, and A. Osman. 2014. Facies and architecture of a tide-dominated segment of the late Pliocene Orinoco Delta (Morne L'Enfer formation) SW Trinidad. Marine and Petroleum Geology 57: 208-232.

Chen, S., R.J. Steel, E.P. Kvale, C. Olariu, and J. Zhang. 2017. Unusually well preserved tidal signals and tidal constituents on Pliocene Paleo-Orinoco Delta Trinidad. Houston: AAPG Datapages/Search and Discovery Article \#90291 O2017 AAPG Annual Convention and Exhibition.

Chen, S.N., W.R. Geyer, and T.J. Hsu. 2013. A numerical investigation of the dynamics and structure of Hyperpycnal River plumes on sloping continental shelves. Journal of Geophysical Research: Oceans 118 (5): 2702-2718.

Chen, Z., D. Chen, K. Xu, Y. Zhao, T. Wei, J. Chen, and M. Watanabe. 2007. Acoustic Doppler current profiler surveys along the Yangtze River. Geomorphology 85: 155-165.

Chikita, K. 1989. A field study on turbidity currents initiated from spring runoffs. Water Resources Research 25: 257-271.

Chu, V.W. 2014. Greenland ice sheet hydrology: a review. Progress in Physical Geography 38 (1): 19-54.

Clare, M.A., J.E. Hughes-Clarke, P.J. Talling, M.J.B. Cartigny, and D.G. Pratomo. 2016 Preconditioning and triggering of offshore slope failures and turbidity currents revealed by most detailed monitoring yet at a fjord-head delta. Earth and Planetary Science Letters 450: 208-220.

Coleman, J.M., and D.B. Prior. 1982. Deltaic environments. In Sandstone depositional environments. AAPG Memoir, ed. P.A. Scholle and D. Spearing, vol. 31, 139-178.

Collins, D.S., H.D. Johnson, P.A. Allison, P. Guilpain, and A.R. Damit. 2017. Coupled 'storm-flood' depositional model: application to the miocene-modern baram delta province, north-west Borneo. Sedimentology 64 (5): 1203-1235.

Cowan, E.A., J. Cai, R.D. Powell, K.C. Seramur, and V.L. Spurgeon. 1998. Modern tida rhythmites deposited in a deep-water estuary. Geo-Marine Letters 18: 40-48.

Cuffey, K.M., and W.S.B. Paterson. 2010. The physics of glaciers. fourth ed, 704 Cambridge: Academic Press. 
Dallimore, C.J., J. Imberger, and B.R. Hodges. 2004. Modeling a plunging underflow. Journal of Hydraulic Engineering 130 (11): 1068-1076.

Dalrymple, R.W. 1992. Tidal depositional systems. In Facies Models: Response to Sea Level Change, GEOtext 1, ed. R.G. Walker and N.P. James, 195-218. St. John's, Newfoundland: Geological Association of Canada.

Dalrymple, R.W., R. John Knight, and J.J. Lambiase. 1978. Bedforms and their hydraulic stability relationships in a tidal environment, bay of Fundy, Canada. Nature 275: 100-104.

Dalrymple, R.W., R.J. Knight, B.A. Zaitlin, and G.V. Middleton. 1990. Dynamics and facies model of a macrotidal sand-bar complex, Cobequid Bay-Salmon River estuary, (bay of Fundy). Sedimentology 37: 577-612.

Dalrymple, R.W., B.A. Zaitlin, and R. Boyd. 1992. Estuarine facies models: Conceptual basis and stratigraphic implications. Journal of Sedimentary Petrology 62: 1130-1146.

Daly, R.A. 1936. Origin of submarine "canyons". American Journal of Science 5 (31): 401-420.

de Jong, M.P.C., and J.A. Battjes. 2004. Low-frequency sea waves generated by atmospheric convection cells. Journal of Geophysical Research: Oceans 109: C01011.

Dierssen, H.M., R.C. Zimmerman, and D.J. Burdige. 2009. Optics and remote sensing of Bahamian carbonate sediment whitings and potential relationship to wind-driven Langmuir circulation. Biogeosciences 6: 487-500.

Dott, R.H.Jr. 1963. Dynamics of subaqueous gravity depositional processes. AAPG Bulletin 47: 104-128.

Enos, P. 1977. Flow regimes in debris flow. Sedimentology 24: 133-142.

Fairbridge, R.W. 1980. The estuary: its definition and geodynamic cycle. In Chemistry and geochemistry of estuaries, ed. E. Olausson and I. Cato, 1-35. New York: Wiley.

Fan, H., H. Huang, T.Q. Zeng, and K. Wang. 2006. River mouth bar formation, riverbed aggradation and channel migration in the modern Huanghe (yellow) river delta, China. Geomorphology 74: 124-136.

Fang, G., and J. Yang. 1985. A two-dimensional numerical model of the tidal motions in the Bohai Sea. Chinese Journal of Oceanology and Limnology 3 (2): 135-152.

Farre, J.A., B.A. McGregor, W.B.F. Ryan, and J.M. Robb. 1983. Breaching the shelfbreak: passage from youthful to mature phase in submarine canyon evolution. In The shelf-break: Critical interface on continental margins, ed. D.J. Stanley and G.T. Moore, vol. 33, 25-39. Tulsa: Society of Economic Paleontologists and Mineralogists Special Publication.

Fisher, R.V., and J.M. Mattinson. 1968. Wheeler gorge turbidite-conglomerate series California - inverse grading. Journal of Sedimentary Petrology 38: 1013-1023.

Forel, F.A. 1885. Les ravins sous-lacustres des fleuves glaciaires. Comptes Rendus de l'Académie des Sciences Paris 101 (16): 725-728.

Forel, F.A. 1892. Le Léman: monographie limnologique. Vol. 1, 543. Lausanne: F. Rouge.

Fossati, M., F. Cayocca, and I. Piedra-Cueva. 2014. Fine sediment dynamics in the Río de la Plata. Advances in Geosciences 39: 75-80.

Fossati, M., and I. Piedra-Cueva. 2013. A 3D hydrodynamic numerical model of the Río de la Plata and Montevideos coastal zone. Applied Mathematical Modelling 37: 1310-1332.

Framiňan, M.B., and O.B. Brown. 1996. Study of the Río de la Plata turbidity front, part l: spatial and temporal distribution. Continental Shelf Research 16: 1259-1282.

Galay, V. 1987. Erosion and sedimentation in the Nepal Himalaya. Vol. 10, 11. Singapore: Kefford Press.

Galloway, W.E. 1976. Sediments and stratigraphic framework of the Copper River fan-delta, Alaska. Journal of Sedimentary Petrology 46: 726-737.

Gao, S., D. Wang, Y. Yang, L. Zhou, Y. Zhao, W. Gao, Z. Han, Q. Yu, and G. Li. 2015. Holocene sedimentary systems on a broad continental shelf with abundant river input: Process-product relationships. In River-dominated shelf sediments of east Asian seas, ed. P.D. Clift, J. Harff, J. Wu, and Y. Qui, vol. 429, 223-259. London: Geological Society, Special Publications.

Gao, W., G. Li, X. Wang, T. Sun, Y. Liu, and L. Cao. 2014. Sedimentary characteristics of the hyperpycnal flow in the modern Yellow River Delta. Indian Journal of Geo-Marine Sciences 43 (8): 1438-1448.

Gihm, Y.S., and I.G. Hwang. 2016. Lacustrine hyperpycnal flow deposits after explosive volcanic eruptions, cretaceous Beolkeum member, Wido Island, Korea. Geosciences Journal 20 (2): 157-166.

Gladstone, C., and D. Pritchard. 2010. Patterns of deposition from experimental turbidity currents with reversing buoyancy. Sedimentology 57: 53-84.

Glossary of Coastal Terminology. 1998. Plunging wave. Department of Ecology Publication, 98-105. State of Washington: Department of Ecology.
Gonzalez-Silvera, A., E. Santamaria-del-Angel, and R. Millán-Núňez. 2006. Spatial and temporal variability of the Brazil-Malvinas Confluence and the La Plata Plume as seen by SeaWiFS and AVHRR imagery. Journal of Geophysical Research 111: C06010.

Guo, L.C., M. van der Wegen, D.A. Jay, P. Matte, Z.B. Wang, D. Roelvink, and Q. He. 2015. River-tide dynamics: Exploration of nonstationary and nonlinear tidal behavior in the Yangtze River estuary. Journal of Geophysical Research: Oceans 120: 3499-3521.

Guo, L.C., M. van der Wegen, J.A. Roelvink, and Q. He. 2014. The role of river flow and tidal asymmetry on 1-D estuarine morphodynamics. Journal of Geophysical Research: Earth Surface 119: 2315-2334.

Hampton, M.A. 1972. The role of subaqueous debris flows in generating turbidity currents. Journal of Sedimentary Petrology 42: 775-793.

Harris, P.T., and T. Whiteway. 2011. Global distribution of large submarine canyons: Geomorphic differences between active and passive continental margins. Marine Geology 285: 69-86.

Hawati, P., D. Nugroho Sugianto, S. Anggoro, A. Wirasatriya, and S. Widada. 2017 Waves induce sediment transport at coastal region of Timbulsloko Demak. IOP conference series. Earth and Environmental Science 55 (1): 012048.

Hoitink, A.J.F., and D.A. Jay. 2016. Tidal river dynamics: implications for deltas. Reviews of Geophysics 54: 240-272.

Hollister, C.D. 1967. Sediment distribution and deep circulation in the western North Atlantic. Ph.D. Dissertation, 467. New York: Columbia University.

Hori, Kl., Q. Zhao, and P. Wang. 2002. Architecture and evolution of the tide-dominated Changjiang (Yangtze) River delta, China. Sedimentary Geology 146: 249-264.

Howe, J.A., M.S. Stoker, and K.J. Woolfe. 2001. Deep-marine seabed erosion and gravel lags in the northwestern Rockall Trough, North Atlantic Ocean. Journal of the Geological Society, the Geological Society of London 158: 427-438.

Hu, C.H., Z.W. Ji, and T. Wang. 1998. Dynamic characteristics of sea currents and sediment dispersion in the Yellow River Estuary. International Journal of Sediment Research 13 (2): 20-30.

Imran, J., and J. Syvitski. 2000. Impact of extreme river events on coastal oceans. Oceanography 13 (3): 85-92.

Jagadeesan, L., R. Jyothibabu, A. Anjusha, A.P. Mohan, N.V. Madhu, K.R. Muraleedharan, and K. Sudheesh. 2013. Ocean currents structuring the mesozooplankton in the Gulf of Mannar and the Palk Bay, southeast coast of India. Progress in Oceanography 110: 27-48.

Johnson, A.M. 1970. Physical Processes in Geology, 577. San Francisco: Freeman, Cooper and Co..

Johnson, K.S., C.K. Paull, J.P. Barry, and F.P. Chavez. 2001. A decadal record of underflows from a coastal river into the deep sea. Geology 29: 1019-1022.

Kassem, A., and J. Imran. 2001. Simulation of turbid underflows generated by the plunging of a river. The Journal of Geology 29 (7): 655-658.

Khan, S.M., J. Imran, S. Bradford, and J.P.M. Syvitski. 2005. Numerical modeling of hyperpycnal plume. Marine Geology 222-223: 193-211.

Khanna, D.R., and P.R. Yadav. 2008. Biology of Coelenterata, 393. Discovery Publishing Pvt. Ltd..

Kostic, S., G. Parker, and J.G. Marr. 2002. Role of turbidity currents in setting the foreset slope of clinoforms prograding into standing fresh water. Journal of Sedimentary Research 72 (3): 353-362.

Kostic, S., and K. Parker. 2003. Progradational sand-mud deltas in lakes and reservoirs. Part 2. Experiment and numerical simulation. Journal of Hydraulic Research 41 (2): 141-152.

Krumbein, W.C., and L.L. Sloss. 1963. Stratigraphy and Sedimentation. 2nd ed, 660 San Francisco: W.H. Freeman and Company.

Lamb, M.P., B. McElroy, B. Kopriva, J. Shaw, and D. Mohrig. 2010. Linking riverflood dynamics to hyperpycnal-plume deposits: experiments, theory, and geological implications. GSA Bulletin 122: 1389-1400.

Lamb, M.P., and D. Mohrig. 2009. Do hyperpycnal-flow deposits record river-flood dynamics? Geology 37 (12): 1067-1070.

Lamb, M.P., J.A. Nittrouer, D. Mohrig, and J. Shaw. 2012. Backwater and river plume controls on scour upstream of river mouths: Implications for fluvio-deltaic morphodynamics. Journal of Geophysical Research: Earth Surface 117: F01002.

Lane, E.W. 1957. A study of the shape of channels formed by natural streams flowing in erodible material. U.S. Army Corps of engineers. Omaha: Missouri River Division.

Lewis, T., S.F. Lamoureux, A. Normandeau, and H.A. Dugan. 2018. Hyperpycnal flows control the persistence and flushing of hypoxic high-conductivity bottom water in a High Arctic lake. Arctic Science 4: 26-41.

Li, G.X., Z.S. Tang, S.H. Yue, K.L. Zhuang, and H.L. Wei. 2001. Sedimentation in the shear front off the Yellow River mouth. Continental Shelf Research 21 (6-7): 607-625. 
Liu, J.P., A.C. Li, K.H. Xu, D.M. Velozzi, Z.S. Yang, J.D. Milliman, and D.J. DeMaster. 2006. Sedimentary features of the Yangtze River-derived along-shelf clinoform deposit in the East China Sea. Continental Shelf Research 26: 2141-2156.

Liu, J.T., Y.H. Wang, R.J. Yang, R.T. Hsu, S.J. Kao, H.L. Lin, and F.H. Kuo. 2012 Cyclone-induced hyperpycnal turbidity currents in a submarine canyon. Journal of Geophysical Research: Oceans 117: C04033.

Liu, K.B., S. Sun, and X. Jiang. 1992. Environmental change in the Yangtze River Delta since 12,000 Years B.P. Quaternary Research 38: 32-45.

Lu, S., C.F. Tong, D.Y. Lee, J.H. Zheng, J. Shen, W. Zhang, and Y.X. Yan. 2015. Propagation of tidal waves up in Yangtze Estuary during the dry season. Journal of Geophysical Research: Oceans 120: 6445-6473.

Luo, Z., J. Zhu, H. Wu, and X. Li. 2017. Dynamics of the sediment plume over the Yangtze Bank in the Yellow and East China Seas. Journal of Geophysical Research: Oceans 122: 10,073-10,090 https://doi.org/10.1002/2017JC013215.

Marr, J.G., P.A. Harff, G. Shanmugam, and G. Parker. 2001. Experiments on subaqueous sandy gravity flows: The role of clay and water content in flow dynamics and depositional structures. GSA Bulletin 113: 1377-1386.

Martín-Chivelet, J., M.A. Fregenal-Martínez, and B. Chacón. 2008. Chapter 10 Traction structures in contourites. In Contourites. Developments in Sedimentology, ed. M. Rebesco and A. Camerlenghi, vol. 60, 159-182. Amsterdam: Elsevier.

Masunaga, E., H. Hommaa, H. Yamazaki, O.B. Fringer, T. Nagai, Y. Kitade, and A. Okayasu. 2015. Mixing and sediment resuspension associated with internal bores in a shallow bay. Continental Shelf Research 110: 85-99.

Matano, R.P., E.D. Palma, and A.R. Piola. 2010. The influence of the Brazil and Malvinas Currents on the southwestern Atlantic shelf circulation. Ocean Science 6: 983-995.

McGowen, J.H., L.E. Garner, and B.H. Wilkinson. 1977. The gulf shoreline of Texas: processes, characteristics, and factors in use, The University of Texas at Austin, Bureau of Economic Geology, Geological Circular. Vol. 77, 27.

McPherson, J.G., G. Shanmugam, and R.J. Moiola. 1987. Fan-deltas and braid deltas: Varieties of coarse-grained deltas. GSA Bulletin 99: 331-340.

Middleton, G.V. 1967. Experiments on density and turbidity currents. III. Deposition of sediment. Canadian Journal of Earth Sciences 4: 475-505.

Middleton, G.V. 1973. Johannes Walther's Law of the correlation of fades. GSA Bulletin 84: 979-988.

Middleton, G.V. 1993. Sediment deposition from turbidity currents. Annual Review of Earth and Planetary Sciences 21: 89-114.

Middleton, G.V., and M.A. Hampton. 1973. Sediment gravity flows: Mechanics of flow and deposition. In Turbidites and deep water sedimentation, ed. G.V. Middleton and A.H. Bouma, 1-38. Los Angeles: Pacific Section SEPM.

Middleton, G.V., and J.B. Southard. 1977. Mechanics of Sediment Movement. SEPM Short Course No. 3, 102. Binghamton: SEPM.

Migeon, S. 2000. Dunes géantes et levées sédimentaires en domainemarin profond: Approche morphologique, sismique et sédimentologique, 288. Talence: Ph.D. Thesis. Université Bordeaux 1.

Mikhailov, V.N., V.I. Kravtsova, and M.V. Isupova. 2015. Impact of reservoirs on the hydrological regime and morphology of the lower reaches and delta of the Zambezi River (Mozambique). Water Resources 42 (2): 170-185.

Milliman, J.D. 2001. River inputs. In Encyclopedia of Ocean Sciences, ed. J.H. Steele, S.A. Thorpe, and K.K. Turekian, 2419-2427. Cambridge: Academic Press.

Milliman, J.D., S.W. Lin, S.J. Kao, J.P. Liu, C.S. Liu, J.K. Chiu, and Y.C. Lin. 2007. Shortterm changes in seafloor character due to flood-derived hyperpycnal discharge: typhoon Mindule, Taiwan, July 2004. Geology 35 (9): 779-782.

Milliman, J.D., and R.H. Meade. 1983. World-wide delivery of river sedment to the oceans. The Journal of Geology 91: 1-21.

Milliman, J.D., H. Shen, Z. Yang, and R.H. Meade. 1985. Transport and deposition of river sediment in the Changjiang estuary and adjacent continental shelf. Continental Shelf Research 4: 37-45.

Mohrig, D., K.X. Whipple, M. Hondzo, C. Ellis, and G. Parker. 1998. Hydroplaning of subaqueous debris flows. GSA Bulletin 110: 387-394.

Moore, D. 1966. Deltaic sedimentation. Earth-Science Reviews 1: 87-104.

Morales de Luna, T., E.D. Fernández Nieto, and M.J. Castro Díaz. 2017. Derivation of a multilayer approach to model suspended sediment transport: Application to hyperpycnal and hypopycnal plumes. Communications in Computational Physics 22 (5): 1439-1485.

Mulder, T., S. Migeon, B. Savoye, and J.-C. Faugères. 2001. Inversely graded turbidite sequences in the deep Mediterranean. A record of deposits from flood-generated turbidity currents? Geo-Marine Letters 21: 86-93.

Mulder, T., S. Migeon, B. Savoye, and J.-C. Faugères. 2002. Reply to discussion by Shanmugam on Mulder et al. (2001, Geo-Marine Letters, 21, 86-93) Inversely graded turbidite sequences in the deep Mediterranean. A record of deposits from flood-generated turbidity currents? Geo-Marine Letters 22: 112-120.
Mulder, T., and J.P.M. Syvitski. 1995. Turbidity currents generated at river mouths during exceptional discharges to the world oceans. The Journal of Geology 103: 285-299.

Mulder, T., J.P.M. Syvitski, S. Migeon, J.-C. Faugères, and B. Savoye. 2003. Marine hyperpycnal flows: Initiation, behavior and related deposits. A review. Marine and Petroleum Geology 20: 861-882.

Münchow, A. 1998. Tidal currents in a topographically complex channel. Continental Shelf Research 18: 561-584.

Mutti, E. 1992. Turbidite sandstones, 275. Milan: Agip Special Publication.

Mutti, E. 2009. The future of field-based stratigraphic and sedimentologic studies from a personal perspective. Journal of Mediterranean Earth Sciences 1: 89-90.

Mutti, E., G. Davoli, and R. Tinterri. 1994. Flood-related gravity-flow deposits in fluvial and fluvio-deltaic depositional systems and their sequencestratigraphic implications. In Second high-resolution sequence stratigraphy conference (tremp, abstract book), ed. H.W. Posamentier and E. Mutti, 137-143.

Mutti, E., G. Davoli, R. Tinterri, and C. Zavala. 1996. The importance of fluviodeltaic systems dominated by catastrophic flooding in tectonically active basins. Memorie di Scienze Geologiche 48: 223-291.

NASA (National Aeronautics and Space Administration), 2017. Earth observatory. Accessed 8 Oct 2017. https://earthobservatory.nasa.gov/.

NOAA (National Oceanic and Atmospheric Administration) Fisheries Glossary. 2006. River Plume. NOAA technical memorandum NMFS-F/SPO-69. Revised edition, U.S. Department of Commerce, 71.

Normark, W.R., and P.R. Carlson. 2003. Giant submarine canyons: is size any clue to their importance in the rock record? GSA Special Paper 370: 175-190.

Ogston, A.S., D.A. Cacchione, R.W. Sternberg, and G.C. Kineke. 2000. Observations of storm and river flood-driven sediment transport on the northern California continental shelf. Continental Shelf Research 20: 2141-2162.

Oxford Dictionaries, 2018. Estuary. https://en.oxforddictionaries.com/definition/estuary.

Palanques, A., X. Durrieu de Madron, P. Puig, J. Fabres, J. Guillén, A. Calafat, M. Canals, S. Heussner, and J. Bonnin. 2006. Suspended sediment fluxes and transport processes in the Gulf of Lions submarine canyons. The role of storms and dense water cascading. Marine Geology 234: 43-61.

Pan, S., H. Liu, C. Zavala, C. Liu, S. Liang, Q. Zhang, and Z. Bai. 2017. Sublacustrine hyperpycnal channel-fan system in a large depression basin: a case study of Nen 1 Member, Cretaceous Nenjiang Formation in the Songliao Basin, NE China. Petroleum Exploration and Development 44 (6): 911-922.

Parker, G., and H. Toniolo. 2007. Note on the analysis of plunging of density flows. Journal of Hydraulic Engineering 133: 690-694.

Parsons, J.D., J.W.M. Bush, and J.P.M. Syvitski. 2001. Hyperpycnal plume formationfrom riverine outfl ows with small sediment concentrations. Sedimentology 48: 465-478.

Paull, C.K., I.I.I.W. Ussler, W.S. Borowski, and F.N. Spiess. 1995. Methane-rich plumes on the Carolina continental rise: associations with gas hydrates. Geology 23 (1): 89-92.

Peliz, A., P. Marchchesiello, A.M.P. Santos, J. Dubert, A. Teles-Machado, and M Marta-Almeida. 2009. Surface circulation in the Gulf of Cadiz: 2. Inflowoutflow coupling and the Gulf of Cadiz slope current. Journal of Geophysical Research: Oceans 114: C03011.

Petter, A.L., and R.J. Steel. 2006. Hyperpycnal flow variability and slope organization on an Eocene shelf margin, central basin, Spitsbergen. AAPG Bulletin 90: 1451-1472.

Pierce, L.E.R. 2012. Poverty shelf, New Zealand from the holocene to present: stratigraphic development and event layer preservation in response to sediment supply, tectonics and climate. Ph.D. Dissertation, 274. Williamsburg: The College of William \& Mary.

Pierson, T.C., and J.E. Costa. 1987. A rheologic classification of subaerial sedimentwater flows. In Debris flows/avalanches: process, recognition, and mitigation, ed. J.E. Costa and G.F. Wieczorek, vol. 7, 1-12. Boulder: Geological Society of America Reviews in Engineering Geology.

Plink-Björklund, P., and R. Steel. 2004. Initiation of turbidity currents: outcrop evidence for eocene hyperpycnal flow turbidites. Sedimentary Geology 165: 29-52.

Postma, G., W. Nemec, and K.L. Kleinspehn. 1988. Large floating clasts in turbidites, a mechanism for their emplacement. Sedimentary Geology 58: 47-61.

Pratson, L.F., W.B.F. Ryan, G.S. Mountain, and D.C. Twichell. 1994. Submarine canyon initiation by downslope-eroding sediment flows: evidence in late cenozoic strata on the New Jersey continental slope. GSA Bulletin 106: 395-412.

Puig, P., A. Palanques, and J. Martín. 2014. Contemporary sediment-transport processes in submarine canyons. Annual Review of Marine Science 6: 53-77.

Purkis, S., G. Cavalcante, L. Rohtla, A.M. Oehlert, P.M. Harris, and P.K. Swart. 2017. Hydrodynamic control of whitings on Great Bahama Bank. Geology 45 (10): 939-942. 
Qiao, L.L., X.W. Bao, D.X. Wu, and X.H. Wang. 2008. Numerical study of generation of the tidal shear front off the Yellow River mouth. Continental Shelf Research 28 (14): 1782-1790.

Rebesco, M., and A. Camerlenghi. 2008. Contourites, developments in sedimentology. Developments in sedimentology, 60, 663. Amsterdam: Elsevier.

Roveri, M., A. Bergamasco, F. Marcello Falcieri, R. Gennari, S. Lugli, V. Manzi, and B. C. Schreiber. 2013. The origin of Messinian canyons in the mediterranean: the role of brine-related dense shelf water cascading currents, EGU2013-EGU4016. Vienna: EGU General Assembly 2013 held 7-12 April, 2013.

Ruppel, C.D., and J.D. Kessler. 2017. The interaction of climate change and methane hydrates. Reviews of Geophysics 55: 126-168.

Saller, A.H., J. Dunham, and R. Lin. 2006. Leaves in turbidite sands: the main source of oil and gas in the deep-water Kutei Basin, Indonesia. AAPG Bulletin 90: $1585-1608$.

Sanders, J.E. 1965. Primary sedimentary structures formed by turbidity currents and related resedimentation mechanisms. In Primary sedimentary structures and their hydrodynamic interpretation, ed. G.V. Middleton, vol. 12, 192-219. Tulsa: SEPM, Special Publication.

Schillereff, D.N., R.C. Chiverrell, N. Macdonald, and J.M. Hooke. 2014. Flood stratigraphies in lake sediments: a review. Earth-Sci Reviews 135: 17-37.

Sepúlveda, H.H., A. Valle-Levinson, and M.B. Framiñan. 2004. Observations of subtidal and tidal flow in the Río de la Plata Estuary. Continental Shelf Research 24: 509-525.

Shanmugam, G. 1996. High-density turbidity currents, are they sandy debris flows? Journal of Sedimentary Research 66: 2-10.

Shanmugam, G. 1997. The Bouma sequence and the turbidite mind set. EarthScience Reviews 42: 201-229.

Shanmugam, G. 2000. 50 years of the turbidite paradigm (1950s-1990s): deepwater processes and facies models - a critical perspective. Marine and Petroleum Geology 17: 285-342.

Shanmugam, G. 2002. Discussion on Mulder et al. 2001, Geo-Marine Letters, 21, 86-93. Inversely graded turbidite sequences in the deep Mediterranean. A record of deposits from flood-generated turbidity currents? Geo-Marine Letters 22: 108-111.

Shanmugam, G. 2003. Deep-marine tidal bottom currents and their reworked sands in modern and ancient submarine canyons. Marine and Petroleum Geology 20: 471-491.

Shanmugam, G. 2006a. Deep-water processes and facies models, implications for sandstone petroleum reservoirs. Vol. 5, 476. Amsterdam: Elsevier, Handbook of Petroleum Exploration and Production.

Shanmugam, G. 2006b. The tsunamite problem. Journal of Sedimentary Research 76: 718-730.

Shanmugam, G. 2008a. The constructive functions of tropical cyclones and tsunamis on deepwater sand deposition during sea level highstand: Implications for petroleum exploration. AAPG Bulletin 92: 443-471.

Shanmugam, G. 2008b. Chapter 5 Deep-water bottom currents and their deposits. In Contourites, developments in sedimentology, ed. M. Rebesco and A. Camerlenghi, vol. 60, 59-81. Amsterdam: Elsevier.

Shanmugam, G. 2012. New perspectives on deep-water sandstones, origin, recognition, initiation, and reservoir quality. In Handbook of petroleum exploration and production, vol. 9, 524. Amsterdam: Elsevier.

Shanmugam, G. 2013. Modern internal waves and internal tides along oceanic pycnoclines: challenges and implications for ancient deep-marine baroclinic sands. AAPG Bulletin 97: 767-811.

Shanmugam, G. 2015. The landslide problem. Journal of Palaeogeography 4 (2): 109-166.

Shanmugam, G. 2016a. Submarine fans: a critical retrospective (1950-2015). Journal of Palaeogeography 5 (2): 110-184.

Shanmugam, G. 2016b. The contourite problem. In Sediment provenance, chapter 9, ed. R. Mazumder, 183-254. Elsevier.

Shanmugam, G. 2016c. The seismite problem. Journal of Palaeogeorapghy 5 (4): 318-362.

Shanmugam, G. 2017a. Global case studies of soft-sediment deformation structures (SSDS): Definitions, classifications, advances, origins, and problems. Journal of Palaeogeorapghy 6 (4): 251-320.

Shanmugam, G. 2017b. Contourites: physical oceanography, process sedimentology, and petroleum geology. Petroleum Exploration and Development 44 (2): 183-216.

Shanmugam, G. 2018a. Climatic and tectonic controls 338 of lacustrine hyperpycnite origination in the late triassic ordos basin, central China: implications for unconventional petroleum development: discussion. AAPG Bulletin 102 in press.

Shanmugam, G., 2018b. A global satellite survey of density plumes at river mouths and at other environments: Plume configurations, external controls, and implications for deep-water sedimentation. Petroleum Exploration and Development, 45(4) in press.

Shanmugam, G.., 2018c. Slides, Slumps, Debris Flows, Turbidity Currents, and Bottom Currents: Implications. In Earth Systems and Environmental Sciences, Elsevier Online Module. 120 p.

Shanmugam, G., 2018d. "Comment on "Ichnological analysis of contourites: Past, present and future" by Francisco J. Rodríguez-Tovar and F. Javier HernándezMolina [Earth-Science Reviews, 182 (2018), 28-41]". Earth-Science Reviews, 187 in press.

Shanmugam, G., and G.L. Benedict. 1978. Fine-grained carbonate debris flow, Ordovician basin margin, Southern Appalachians. Journal of Sedimentary Petrology 48: 1233-1240.

Shanmugam, G., J.E. Damuth, and R.J. Moiola. 1985. Is the turbidite facies association scheme valid for interpreting ancient submarine fan environments? Geology 13: 234-237.

Shanmugam, G., and R.J. Moiola. 1988. Submarine fans: characteristics, models, classification, and reservoir potential. Earth-Science Reviews 24: 383-428.

Shanmugam, G., M. Poffenberger, and J. Toro Alava. 2000. Tide-dominated estuarine facies in the Hollin and Napo ('T' and ' $U$ ') formations (Cretaceous), Sacha Field, Oriente Basin, Ecuador. AAPG Bulletin 84: 652-682.

Shanmugam, G., S.K. Shrivastava, and B. Das. 2009. Sandy debritesand tidalites of Pliocene reservoir sands in upper-slope canyon environments, offshore Krishna-Godavari Basin (India): implications. Journal of Sedimentary Research 79: 736-756.

Shanmugam, G., T.D. Spalding, and D.H. Rofheart. 1993. Process sedimentology and reservoir quality of deep-marine bottom-current reworked sands (sandy contourites): an example from the Gulf of Mexico. AAPG Bulletin 77: 1241-1259.

Shepard, F.P. 1981. Submarine canyons: multiple causes and long-time persistence. AAPG Bulletin 65: 1062-1077.

Shepard, F.P., and R.F. Dill. 1966. Submarine canyons and other sea valleys, 381. Chicago: Rand McNally \& Co..

Shepard, F.P., N.F. Marshall, P.A. McLoughlin, and G.G. Sullivan. 1979. Currents in submarine canyons and other sea valleys. AAPG Studies in Geoloy 8: 173.

Shillington, F.A., L. Hutchings, T.A. Probyn, H.N. Waldron, and W.T. Peterson. 1992 Filaments and the Benguela frontal zone: Offshore advection or recirculating loops? South African Journal of Marine Science 12 (1): 207-218.

Shipley, S., and A.M. Sarna-Wojcicki. 1982. Distribution, thickness, and mass of late pleistocene and holocene tephra from major volcanoes in the northwestern United States: a preliminary assessment of hazards from volcanic ejecta to nuclear reactors in the Pacific Northwest. US Geological Survey Miscellaneous Field Studies Map MF-1435.

Soyinka, O.A., and R. Slatt. 2008. Identification and microstratigraphy of hyperpycnites and turbidites in Cretaceous Lewis Shale, Wyoming. Sedimentology 55: 1117-1133.

Sridhar, P.N., I. Ramana, M.M. VAli, and B. Veeranarayana. 2008. Understanding the suspended sediment dynamics in the coastal waters of the Bay of Bengal using high resolution ocean colour data. Current Science 94 (11): 1499-1502.

Steel, E., A.R. Simms, J. Warrick, and Y. Yokoyama. 2016. Highstand shelf fans: The role of buoyancy reversal in the deposition of a new type of shelf sand body. GSA Bulletin 128: 1717-1724.

Steel, E., A.R. Simms, R. Steel, and C. Olariu. 2018. Hyperpycnal delivery of sand to the continental shelf: insights from the Jurassic lajas formation, Neuquén Basin, Argentina. Sedimentology https://doi.org/10.1111/sed.12460.

Stow, D.A.V., and J.C. Faugères. 2008. Chapter 13 Contourite facies and the facies model. In Contourites, developments in sedimentology, ed. M. Rebesco and A. Camerlenghi, vol. 60, 223-256. Amsterdam: Elsevier.

Stow, D.A.V., and M. Johansson. 2000. Deep-water massive sands: nature, origin and hydrocarbon implications. Marine and Petroleum Geology 17: 145-174.

Sun, F.N., R.C. Yang, and D.Y. Li. 2016. Research progresses on hyperpycnal flow deposits. Acta Sedimentologica Sinica 34 (3): 452-462 (in Chinese with English Abstract).

Takahashi, T. 1981. Debris flows. Annual Review of Fluid Mechanics 13: 57-77.

Talley, L.D. 2013. Closure of the global overturning circulation through the Indian, Pacific, and Southern Oceans: Schematics and transports. Oceanography 26 (1): 80-97.

Talling, P.J. 2014. On the triggers, resulting flow types and frequencies of subaqueous sediment density flows in different settings. Marine Geology 352: 155-182.

Talling, P.J., D.G. Masson, F.J. Sumner, and G. Malgesini. 2012. Subaqueous sediment density flows, depositional processes and deposit types. Sedimentology 59: 1937-2003.

Turner, J.S. 1980. Buoyancy Effects in Fluids. Series: Cambridge monographs on mechanics, 412. Cambridge University Press. 
Van der Lingen, G.J. 1969. The turbidite problem. New Zealand Journal of Geology and Geophysics 12 (1): 7-50.

van Maren, D.S., J.C. Winterwerp, B.S. Wu, and J.J. Zhou. 2009. Modelling hyperconcentrated flow in the Yellow River. Earth Surface Processes and Landforms 34 (4): 596-612.

Visser, M.J. 1980. Neap-spring cycles reflected in Holocene subtidal large-scale bedform deposits: a preliminary note. Geology 8: 543-546.

Walker, N.D. and L.J. Rouse, Jr. 1993. Satellite assessment of Mississippi River discharge plume variability. OCS Study MMS 93-0044. U.S. Dept. of the Interior, Minerals Management Service, Gulf of Mexico OCS Regional Office, New Orleans, La. 50 p.

Wang, H., N. Bi, Y. Wang, Y. Saito, and Z. Yang. 2010. Tide-modulated hyperpycnal flows off the Huanghe (Yellow River) Mouth, China. Earth Surface Processes and Landforms 35 (11): 1315-1329.

Wang, H.J., Z.S. Yang, Y.H. Li, Z.G. Guo, X.X. Sun, and Y. Wang. 2007. Dispersion pattern of suspended sediment in the shear frontal zone off the Huanghe (Yellow River) mouth. Continental Shelf Research 27 (6): 854-871.

Wang, H.J., Z.S. Yang, Y. Saito, J.P. Liu, and X.X. Sun. 2006. Interannual and seasonal variation of the Huanghe (Yellow River) water discharge over the past 50 years: connections to impacts from ENSO events and dams. Global and Planetary Change 50 (3): 212-225.

Wang, N., G.X. Li, L.L. Qiao, J.H. Shi, P. Dong, J.S. Xu, and Y.Y. Ma. 2017. Long-term evolution in the location, propagation, and magnitude of the tidal shear front off the Yellow River mouth. Continental Shelf Research 137: 1-12.

Wang, N., G.X. Li, J.S. Xu, L.L. Qiao, O.A. Dada, and C.Y. Zhou. 2015. The marine dynamics and changing trend off the modern Yellow River mouth. Journal of Ocean University of China 14 (3): 433-445.

Wang, Q., X.Y. Guo, and H. Takeoka. 2008. Seasonal variations of the Yellow River plume in the Bohai sea: a model study. Journal of Geophysical Research: Oceans 113: C08046.

Wang, X.H., and H.J. Wang. 2010. Tidal straining effect on the suspended sediment transport in the Huanghe (Yellow River) Estuary, China. Ocean Dynamics 60: 1273-1283.

Warne, A.G., R.H. Meade, W.A. White, A. Aslan, E.H. Guevara, J.C. Gibeaut, R.C. Smyth, and T. Tremblay. 2002. Regional controls on geomorphology, hydrology, and ecosystem integrity of the Orinoco Delta, Venezuela. Geomorphology 44: 273-307.

Warrick, J.A., A.R. Simms, A. Ritchie, E. Steel, P. Dartnell, J.E. Conrad, and D.P. Finlayson. 2013. Hyperpycnal plumederived fans in the Santa Barbara channel, California. Geophysical Research Letters 40: 2081-2086.

Wilson, R.D., and J. Schieber. 2014. Hyperpycnites in the lower genesee group of central New York, USA: implications for mud transport in epicontinental seas. Journal of Sedimentary Research 84: 866-874.

Wilson, R.D., and J. Schieber. 2017. Sediment transport processes and lateral facies gradients across a muddy shelf: examples from the Geneseo formation of central New York, United States. AAPG Bulletin 101: 423-431.

Wiseman, W.J., Jr., Y.B. Fan, B.D. Bornhold, G.H. Keller, Z.Q. Su, D.B. Prior, Z.X. Yu, L.D. Wright, F.Q. Wang, and Q.Y. Qian. 1986. Suspended sediment advection by tidal currents off the Huanghe (Yellow River) delta. Geo-Marine Letters 6 (2): 107-113.

Wright, L.D., C. Friedrichs, S. Kim, and M. Scully. 2001. Effects of ambient currents and waves on gravity-driven sediment transport on continental shelves. Marine Geology 175: 25-45.

Wright, L.D., W.J. Wiseman, B.D. Bornhold, D.B. Prior, J.N. Suhayda, G.H. Keller, Z.S. Yang, and Y.B. Fan. 1988. Marine dispersal and deposition of Yellow River silts by gravity-driven under flows. Nature 332: 629-632.

Wright, L.D., W.J. Wiseman, Z.S. Yang, B.D. Bornhold, G.H. Keller, D.B. Prior, and J.N. Suhayda. 1990. Processes of marine dispersal and deposition of suspended silts off the modern mouth of the Huanghe (Yellow River). Continental Shelf Research 10: 1-40.

Wright, L.D., Z.S. Yang, B.D. Bornhold, G.H. Keller, D.B. Prior, and W.J. Wiseman Jr. 1986. Hyperpycnal plumes and plume fronts over the Huanghe (Yellow River) delta front. Geo-Marine Letters 6: 97-105.

Wu, J., J. Ren, H. Liu, C. Qiu, Y. Cui, and Q. Zhang. 2016. Trapping and escaping processes of Yangtze river-derived sediments to the East China sea. In Riverdominated shelf sediments of East Asian seas, ed. P.D. Clift, J. Harff, J. Wu, and Y. Qui, vol. 429, 153-169. London: Geological Society, Special Publications.

Yang, R., Z. Jin, A.J. van Loon, Z. Han, and A. Fan. 2017a. Climatic and tectonic controls of lacustrine hyperpycnite origination in the Late Triassic Ordos Basin, central China: implications for unconventional petroleum development. AAPG Bulletin 101 (1): 95-117.
Yang, T., Y. Cao, and Y. Wang. 2017b. A new discovery of the early cretaceous supercritical hyperpycnal flow deposits on Lingshan island, East China. Acta Geologica Sinica (English Edition) 91 (2): 749-750.

Yao, Z.G., R.Y. He, X.W. Ban, and D.X. Wu. 2012. M2 tidal dynamics in Bohai and Yellow Seas: a hybrid data assimilative modeling study. Ocean Dynamics 62: 753-769.

Yu, J., Y. Fu, Y. Li, G. Han, Y. Wang, D. Zhou, W. Sun, Y. Gao, and F.X. Meixner. 2011. Effects of water discharge and sediment load on evolution of modern Yellow River Delta, China, over the period from 1976 to 2009. Biogeosciences 8 (9): 2427-2435

Zavala, C., and M. Arcuri. 2016. Intrabasinal and extrabasinal turbidites: Origin and distinctive characteristics. Sedimentary Geology 337: 36-54

Zavala, C., and S.X. Pan. 2018. Hyperpycnal flows and hyperpycnites: origin and distinctive characteristics. Lithologic Reservoirs 30 (1): 1-27.

Zavala, C., J. Ponce, D. Drittanti, M. Arcuri, H. Freije, and M. Asensio. 2006. Ancient lacustrine hyperpycnites: a depositional model from a case study in the rayoso formation (cretaceous) of west-central Argentina. Journal of Sedimentary Research 76: 41-59.

Zhang, E.F., H.H.G. Savenije, S.L. Chen, and X.H. Mao. 2012. An analytical solution for tidal propagation in the Yangtze Estuary, China. Hydrology and Earth System Sciences 16 (9): 3327-3339.

Zhang, W., H. Feng, A.J.F. Hoitink, Y. Zhu, F. Gong, and J. Zheng. 2017. Tida impacts on the subtidal flow division at the main bifurcation in the Yangtze River Delta. Estuarine, Coastal and Shelf Science 196: 301-314.

Zou, C.N., L. Wang, Y. Li, S.Z. Tao, and L.H. Hou. 2012. Deep-lacustrine transformation of sandy debrites into turbidites, Upper Triassic, Central China. Sedimentary Geology 265-266: 143-155.

\section{Submit your manuscript to a SpringerOpen ${ }^{\circ}$ journal and benefit from:}

- Convenient online submission

- Rigorous peer review

- Open access: articles freely available online

- High visibility within the field

- Retaining the copyright to your article

Submit your next manuscript at $>$ springeropen.com 